University of Louisville

ThinkIR: The University of Louisville's Institutional Repository

Electronic Theses and Dissertations

$12-2011$

\title{
Effects of environmental pollution on endothelial progenitor cells and vascular regeneration.
}

Laura A. Wheat Nissley 1983-

University of Louisville

Follow this and additional works at: https://ir.library.louisville.edu/etd

\section{Recommended Citation}

Nissley, Laura A. Wheat 1983-, "Effects of environmental pollution on endothelial progenitor cells and vascular regeneration." (2011). Electronic Theses and Dissertations. Paper 1065.

https://doi.org/10.18297/etd/1065

This Doctoral Dissertation is brought to you for free and open access by ThinkIR: The University of Louisville's Institutional Repository. It has been accepted for inclusion in Electronic Theses and Dissertations by an authorized administrator of ThinkIR: The University of Louisville's Institutional Repository. This title appears here courtesy of the author, who has retained all other copyrights. For more information, please contact thinkir@louisville.edu. 


\title{
EFFECTS OF ENVIRONMENTAL POLLUTION ON ENDOTHELIAL PROGENITOR CELLS AND VASCULAR REGENERATION
}

\author{
By \\ Laura A. Wheat Nissley \\ A.S., Lindsey Wilson University, 2006 \\ B.S., Lindsey Wilson University, 2006 \\ M.S., University of Louisville, 2008 \\ A dissertation \\ Submitted to the Faculty of the \\ School of Medicine the University of Louisville \\ in Partial Fulfillment of the Requirements \\ for the Degree of \\ Doctor of Philosophy \\ Department of Physiology and Biophysics \\ University of Louisville \\ Louisville, Kentucky
}

December 2011 


\title{
EFFECTS OF ENVIRONMENTAL POLLUTION ON ENDOTHELIAL PROGENITOR CELL AND VASCULAR REGENERATION
}

\author{
By \\ Laura A. Wheat Nissley \\ A.S., Lindsey Wilson College, 2006 \\ B.S., Lindsey Wilson College, 2006 \\ M.S., University of Louisville, 2007 \\ A Dissertation Approved on \\ November $18^{\text {th }} 2011$ \\ By the following Dissertation Committee:
}

Advisor: Aruni Bhatnagar, Ph.D.

William Wead, Ph.D.

Daniel Conklin, Ph.D.

Suresh Tyagi, Ph.D.

Stanley D'S6uza, Ph.D. 


\section{ACKNOWLEDGMENTS}

This dissertation is dedicated to my loving husband Mervin and family. My husband has been my rock I could always lean on and is the true love of my life. My family is and always will be the primary inspiration, joy and the reason I have always and will always work so hard to accomplish my goals. No matter how long my hours were or how far away I was, my husband and family always stood by me and my decisions and gave me strength through the hard times. They helped me never forget what I stood for and my morals that makes' me the person that I am. I would also like to thank Dr. Kenneth Schickler for keeping me alive for the past 25 years which wasn't easy. I wasn't always the best patient but he was always the best doctor, thanks to you I have lived to see my educational goals accomplished. I would also like to thank my co-authors and co-workers for contributing to this thesis and my educational training; Jason Hellmann, Petra Haberzetll, Timothy O'Toole, Daniel Conklin, James McCracken, and Mathew Burtke without their hard work and dedication none of this would have been possible. I would also like to acknowledge those who guided my scientific journey along the way, I would like to thank my mentor Dr. Aruni Bhatnagar, his 
dedication and pride in his work and lab is truly inspiring and motivational. Also, to Dr. William B. Wead for continued support throughout the years, to those I am truly grateful. 


\title{
ABTRACT \\ ACROLEIN SUPPRESSES MOBILIZATION OF ENDOTHELIAL PROGENITOR CELLS
}

\author{
Laura Anne Wheat Nissley
}

December $16^{\text {th }} 2011$

Acrolein is a common pollutant present in ambient air, automobile exhaust, and tobacco smoke. Previous studies show that exposure to acrolein increases cardiovascular disease risk. To determine whether acrolein affect cardiovascular regeneration, we investigated the cardiovascular effects of inhaled acrolein. Adult male C57BL/6 mice were exposed to room air or acrolein $(0.5,1$ or $5 \mathrm{ppm})$ for and the endothelial progenitor cells (EPC) level in peripheral blood (PB) was measured by flow cytometry. To examine the proliferative capacity of EPCs, bone marrow cells (BMCs) were cultured on fibronectin-coated slides. Brief exposure to acrolein (5 ppm, 6h) or 4 day (1 ppm) exposure led to a $42 \%$ decrease in $\mathrm{PB} \mathrm{Flk} / \mathrm{Sca}^{+}$cells. BMCs isolated from mice exposed to acrolein for $1 \mathrm{~d}(5 \mathrm{ppm})$ or $4 \mathrm{~d}(1 \mathrm{ppm})$ formed more colonies than BMCs of airexposed mice. Combined VEGF-A (100 $\mu \mathrm{g} / \mathrm{kg}$, ip, 4d) and AMD3100 (5 mg/kg; ip, last day only) treatment increased PB EPCs cells in air-exposed mice but not in acrolein-exposed mice (1 ppm, 4d). These data indicate that circulating EPCs 
are a sensitive target of airborne pollutants and that acrolein at concentrations encountered in tobacco smoke suppresses EPC levels in the blood but it increases the proliferative capacity of EPCs in the bone marrow. My thesis is that EPCs are sensitive targets for environmental insults, such as acrolein, thus increasing the risk of developing cardiovascular disease and endothelial dysfunction. Studies here show that the effects of acrolein on EPC after exposure by inhalation (Aim 1), the environmental pollutant acrolein, prevents mobilization of EPCs by cytokine stimulation (Aim 2), evaluated perfusion recovery of hindlimb ischemia after exposure to acrolein inhalation (Aim 3).

The results of these studies support the hypothesis that exposure to environmental pollutant acrolein prevents EPC mobilization. 


\section{TABLE OF CONTENTS}

\section{PAGE}

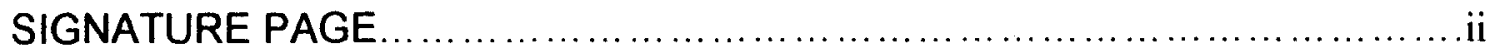

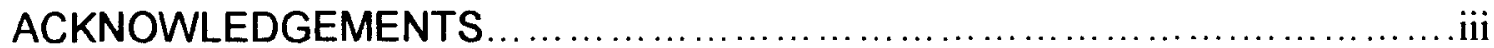

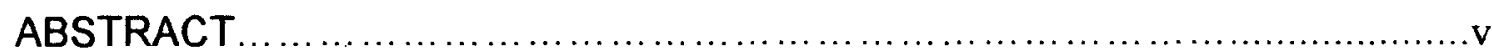

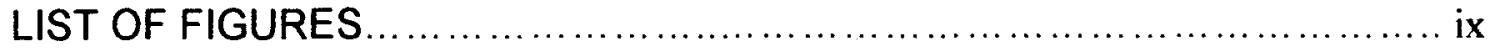

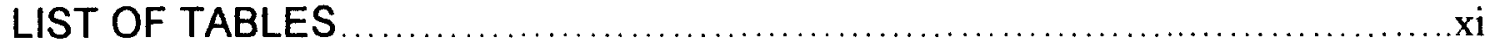

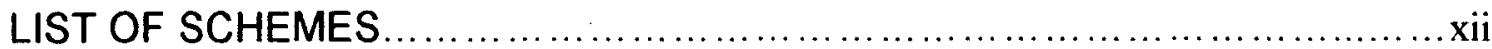

\section{CHAPTER}

I. GENERAL INTRODUCTION

a. Environmental pollution and cigarette smoke..............1

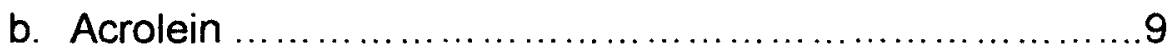

c. Endothelial Progenitor Cells ........................... 18

- Definition......................................... 19

- Mobilization....................................21

- Recruitment.......................................... 24

- Transmigration.................................26

- Differentiation......................................28

- Endothelial progenitor cell resident tissue

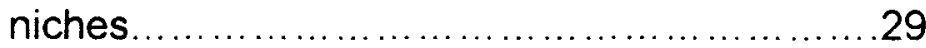

d. Goal of the Project......................................... 33 


\section{ACROLEIN INHALATION DECREASES CIRCULATING LEVELS OF ENDOTHELIAL PROGENITOR CELLS}

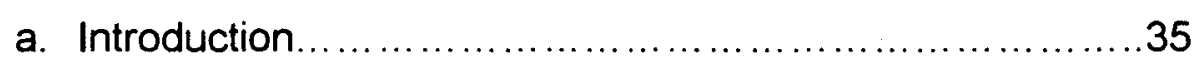

b. Experimental Procedures.................................47

c. Results....................................................... 50

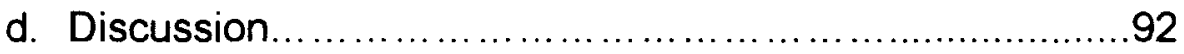

e. Special acknowledgments............................... 96

III. ACROLEIN EFFECTS ON ANGIOGENESIS

a. Introduction ............................................... 97

b. Experimental Procedures..................................98

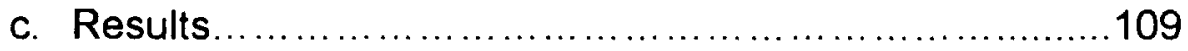

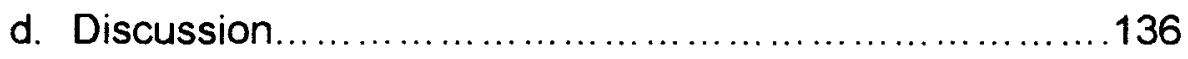

IV. CONCLUDING DISCUSSION ................................. 138

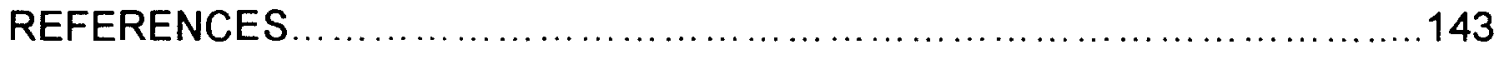

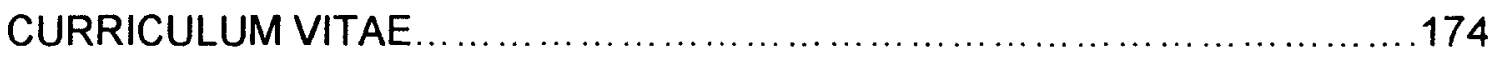




\section{LIST OF FIGURES}

\section{FIGURES}

PAGE

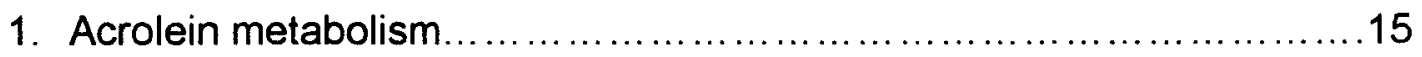

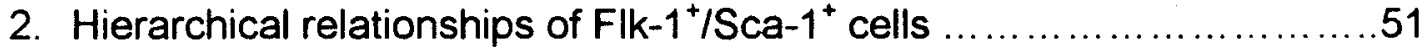

3. Characterization of $\mathrm{Flk}-1^{+} / \mathrm{Sca}-1^{+}$progenitor cells by flow cytometry ......55

4. Effects of acrolein on circulating progenitor cells ........................6

5. Acrolein increases proliferation of bone marrow-derived cells............68

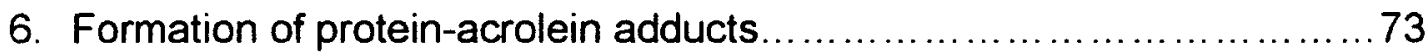

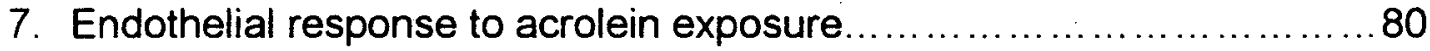

8. Effects of acrolein on enzymatically important constitiunts of EPC

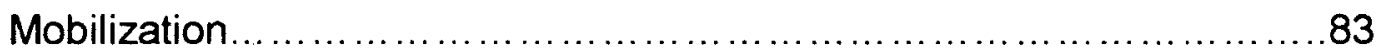

9. Effects of acrolein on mobilization of Flk-1 $1^{+} / \mathrm{Sca}-1^{+}$cells...................87

10. Representative photo of $5 \mathrm{~mm}$ punch wound model....................103

11. Representative photo of hindlimb ischemia animal preparation

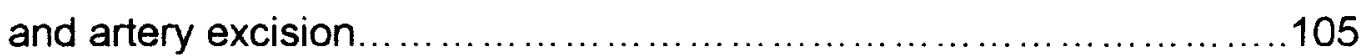

12. Representative photo of muscle harvest for hindlimb ischemia

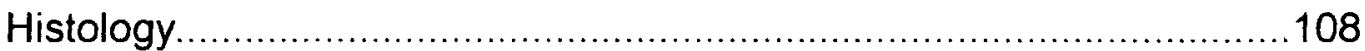

13. Acrolein treatments effect on a model of In Vitro angiogenesis.......... 110 
15. Acrolein inhalation and mouse punch wound model.

16. Hind limb ischemia perfusion recovery and $1 \mathrm{ppm}$ acrolein inhalation....127

17. Hind limb ischemia perfusion recovery and 2 ppm acrolein inhalation...132 


\section{LIST OF TABLES}

\section{TABLES}

\section{PAGE}

1. Cigarette chemical content...............................................

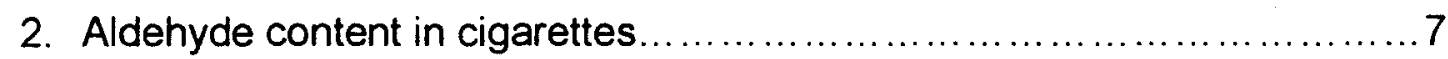

3. Source and level of acrolein emissions ..............................11

4. Methods for acrolein sampling and testing ............................12

5. Commonly used EPC markers and definition .........................20

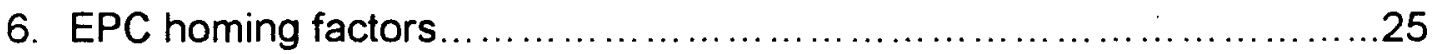

7. Blood and plasma variable in mice exposed to air or acrolein.............65

8. Complete blood count in mice exposed to air or acrolein .................66

9. Vascular effects of air or acrolein exposure in mice ......................78

10. Complete blood counts in mice exposed to air or acrolein.................91

11. Blood parameters in C57BL/6 mice exposed to air or acrolein with

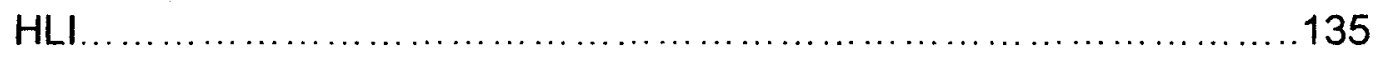




\section{LIST OF SCHEMES}

\section{SCHEMES}

\section{PAGE}

1. Hypoxic injury and mobilization of EPCs from bone marrow............23

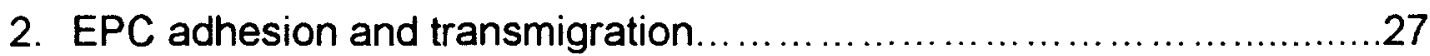

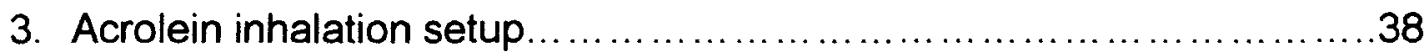

4. $1 \mathrm{ppm}$ acrolein exposure stability level................................39

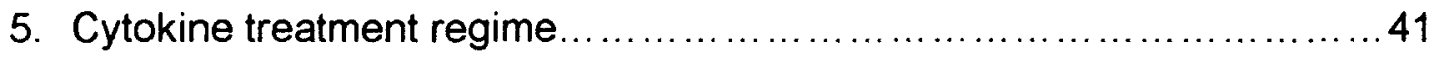

6. Acrolein inhalation setup ............................................. 101

7. Two day hindlimb ischemia surgery protocol..........................114

8. Two day punch wound protocol.....................................122

9. Ten day hindlimb ischemia surgery protocol.......................... 122

10. Twenty day hindlimb ischemia surgery protocol .......................126

11. Ten day hindlimb ischemia surgery protocol ...........................131 


\section{CHAPTER I}

\section{GENERAL INTRODUCTION}

\section{ENVIRONMENTAL POLLUTION AND CIGARETTE SMOKE}

The United States and other industrialized countries face an increasing amount of air pollution and related health concerns. The World Health

Organization $(\mathrm{WHO})$ data base has estimated that 1.5 billion people in the world are exposed to dangerously high levels of pollution on a daily basis ${ }^{1}$. WHO also estimates 3 million deaths are attributed to outdoor air pollution and 1.6 million deaths are attributed to indoor-air pollution ${ }^{2}$. The earth's atmosphere itself is a complex mixture of gases, changing in composition with each atmospheric layer. However, when defining environmental pollution the two layers of concern are the troposphere and stratosphere. The troposphere is the lowest portion of the earth's atmosphere, it contains approximately $80 \%$ of the total atmosphere mass and $99 \%$ of its water vapor and aerosols and the ozone layer is located within the stratosphere.

When defining pollution Webster dictionary simply states, "pollution is the introduction of contaminants into a natural environment that causes instability, disorder, harm or discomfort to the ecosystem i.e. physical systems 
or living organisms". The EPA in conjunction with the Commission for Environmental Cooperation estimates each year the United States alone spews 3 million tons of toxic chemicals into the air, water and land ${ }^{3}$. There are also naturally occurring sources of pollution such as volcanic eruptions, pollen, mold, sulfur release from oceans and forest fires ${ }^{4-8}$. For the most part, pollution is man-made, has many sources and has escalated since the dawn of the industrial revolution. However, pollution isn't just a plague of modern society even in prehistoric time man was exposed to pollution. Scientists have found signs of indoor pollution on cave walls in the form of soot that resulted from building fires for heating and cooking with no or little ventilation $^{9}$. Modern pollution can still be attributed to wood burning but also the combustion of any petroleum product or byproduct, smelting, agriculture, cooking, coal burning, production of plastic, foam, energy, and nuclear power; the list goes on ${ }^{10-14}$. Historically, pollution has been associated with severe or even life threatening health conditions. Cigarette smoke and second hand cigarette smoke exposure is a well publicized and published pollutant that is directly linked to the development of cancer; but can cause asthma, emphysema, decreased birth weight, increased risk for heart disease, stroke, coronary heart disease, and overall increased morbidity ${ }^{15-19}$.

The EPA has classified 5 major pollutants; ozone $\left(\mathrm{O}_{3}\right)$, carbon monoxide (CO), nitrogen oxides (NO), particulate matter $(\mathrm{PM})$, sulfur dioxide $\left(\mathrm{SO}_{2}\right)$, and lead. Each pollutant is produced from a number of sources and can have varying health effects. Ozone is a colorless gas that constitutes photochemical smog at the earth's surface. Ozone is formed in the lower troposphere as a result of chemical reactions between oxygen, volatile organic compounds and nitrogen oxides in the presence of 
sunlight ${ }^{20}$. Ozone has been associated with significant health problems including impaired lung function, chest pain, cough and lung inflammation ${ }^{21,22}$. Carbon monoxide is an odorless colorless gas emitted from the exhaust of vehicles and other kinds of engines where there is incomplete fossil fuel combustion ${ }^{23}$. Carbon monoxide reduces the ability of blood to deliver oxygen to vital tissues, effecting primarily the cardiovascular and nervous systems ${ }^{24-26}$. Nitrogen dioxide is a light brown gas that results from the burning of fossil fuels in utilities, cars, and trucks ${ }^{23}$. Nitrogen dioxide is the major cause of smog, acid rain and at high levels can be harmful to not only humans but vegetation as well ${ }^{27,28}$. Particulate matter (PM) can be solid or liquid droplets from smoke, dust, fly ash and condensed vapors. Particulate matter is produced from industrial processes, smelters, automobiles, burning industrial fuels, wood smoke, and dust from unpaved roads ${ }^{29}$. These microscopic particles can affect breathing, respiratory tract health, increased respiratory disease, lung damage and linked to increased morbidity ${ }^{30,31}$. Sulfur dioxide is a colorless odorless gas emitted largely from industrial, institutional, utility, and apartment-house furnaces and boilers, as well as smelters, paper mills, petroleum refineries, and chemical plants ${ }^{32,33}$. Sulfur dioxide is one of the major pollutants that causes smog and can affect susceptible individuals like asthmatics ${ }^{23,34}$. Lead and lead compounds can adversely affect human health by either ingestion or direct inhalation of contaminated soil, dust, paint ${ }^{35}$. Exposure to lead can affect mental development, kidney function, and blood chemistry 36,37

History has shown that exposure to increased amounts of pollution can be devastating. There have been several acute incidences displaying the effect that 
pollution has on human health, and mortality. Several cities and towns have encountered these events first hand. Notable pollution related deaths have occurred in the past due to weather inversions in conjunction with increased industrial activity in low lying areas. One of the earliest recorded cases was in the Meuse Valley in Belgium, December 1930, killing 60 and sickening another 6,000 people. Deaths were attributed to "episodes of severe pulmonary attacks". Investigators pointed to the probability that sulfur dioxide $\left(\mathrm{SO}_{2}\right)$ or oxidation products of that compound from factory smoke along with unusual weather patterns were the cause ${ }^{38}$. In 1948 over a span of 2 days the small town of Donora, Pennsylvania also suffered severe casualties. Thick smog trapped from an iron smelting plant combined with weather inversion, was responsible for killing 20 people and sickening 6,000 more $^{39}$. Years later in 1952 , 12,000 people died and 100,000 were sickened by pollution and stalled weather patterns in greater downtown London, England. Thousands of tons of black soot, tar particles, and sulfur dioxide had accumulated in the air due to the heavy coal combustion from factories along the river Thames. Estimates of $\mathrm{PM}_{10}$ concentrations during December, 1952, range between 3,000 and $14,000 \mu \mathrm{g} / \mathrm{m}^{3}$ with the high range being approximately 50 times higher than normal levels ${ }^{40,41}$. After this incident it became evident the Donora disaster was just the beginning and led the United States Congress to pass the first air pollution policy in 1955, the Air Pollution Clean Act. This policy was later followed by the formation and implementation of the EPA in 1970 by President Richard Nixon ${ }^{42,43}$.

Depending on the geographic location, population density, and level of industrialization; pollution can vary in concentration and composition. Hong Kong, 
China has a population of 7.2 million and a population density of 16,576 people/mile ${ }^{2}$. Hong Kong is highly industrialized with little emission control policies enforced on industry. Therefore, it is not surprising that Hong Kong is one of the most polluted cities in the world ${ }^{44}$. The major 5 recognized pollutants vary in concentration; $\mathrm{SO}_{2} 350 \mu \mathrm{g} / \mathrm{m}^{3}$, PM $180 \mu \mathrm{g} / \mathrm{m}^{3}$, NO $150 \mu \mathrm{g} / \mathrm{m}^{3}$, CO $10,000 \mu \mathrm{g} / \mathrm{m}^{3}, \mathrm{O}_{3} 24 \mu \mathrm{g} / \mathrm{m}^{3}{ }^{45,46}$. Compared to Hong Kong, Los Angeles, California has drastically different levels of pollution. Los Angeles has a population of 3.8 million and density of 7,544 people/mile ${ }^{2}$,California boasts extremely strict emission control laws and has a different industrial base, which accounts for the vast difference when compared to Hong Kong. The major 5 pollutants in ambient Los Angeles air; $\mathrm{SO}_{2} 0.43 \mu \mathrm{g} / \mathrm{m}^{3}, \mathrm{PM} 39 \mu \mathrm{g} / \mathrm{m}^{3}$, NO $14.3 \mu \mathrm{g} / \mathrm{m}^{3}$, CO 304 $\mu \mathrm{g} / \mathrm{m}^{3}, \mathrm{O}_{3} 13 \mu \mathrm{g} / \mathrm{m}^{3} 47,48$. When levels of these pollutants reach high enough levels, they can be hazardous or even deadly upon exposure and can cause serious health effects with long term repeated exposure. The Occupational Safety and Health Administration (OSHA) has compiled permissible exposure limits (PELs) for hundreds of pollutants. Studies have found there are no real "safe" or acceptable exposure concentrations of troposphere or ground-level ozone exposure. Overtime, exposure to ozone will have negative health related effects, but OSHA ozone PELs is $0.075 \mathrm{ppm} / 8 \mathrm{hr}$ day. Sulfur dioxide PELs are not to exceed $140 \mathrm{pbb}$ in a $24 \mathrm{hr}$ period. Particulate matter PELs are not to exceed $\left(\mathrm{PM}_{2.5}\right) 35 \mu \mathrm{g} / \mathrm{m}^{3}$ per 24 hour period, $\left(\mathrm{PM}_{10}\right) 150 \mu \mathrm{g} / \mathrm{m}^{3}$ per 24 hour period. Acceptable nitric oxide exposure levels have become more stringent, individuals are not to exceed $100 \mathrm{ppb} / \mathrm{hr}$ of exposure. Carbon dioxide standards allow individual exposures to reach $9 \mathrm{ppm} / 8 \mathrm{hr}$ day. OSHA has found these safety standard exposure levels to have no long-term health effects. However, data now show for every 
$10 \mu \mathrm{g} / \mathrm{m}^{3}$ of city specific particulate matter $_{2.5}$ the mortality ratio rate $(R R)$ is 1.13 , demonstrating an inverse correlation between pollution levels and mortality ${ }^{49,50}$. Environmental tobacco smoke (ETS) is a pollutant associated with severe health consequences. Smoke from cigarettes is a complex mixture of 4,000 different chemicals; 50 known carcinogens; 200 known poisons. ETS is made up of a combination of side stream and mainstream cigarette smoke. Side stream cigarette smoke is smoke coming off the end of a smoldering cigarette. Mainstream smoke is considered active smoking, the combination of inhaling and exhaling after taking a puff on a lit cigarette. The frequency of puffs, duration and volume all contribute to the make-up of mainstream smoke ${ }^{51,52}$. Each of the chemicals in cigarettes varies depending on brand and country of origin (Table 1) 53-57. Studies have shown that exposure levels increase significantly from mainstream smoke to side stream smoke, particulate matter significantly increases by 5 fold like ${ }^{58}$. Even though combustable tobacco products are full of numerous chemical aldehydes are highly reactant and abundant within cigarette smoke (Table 2). Even though acrolein is not necessarily the most prevalent of the aldehydes it is one of the most reactive. 
Table 1: Cigarette chemical content (one burned cigarette) ${ }^{53-57}$

\begin{tabular}{|l|l|l|l|l|l|}
\hline Brand & Acrolein & CO & Nicotine & Tar & $\begin{array}{l}\text { Country or } \\
\text { origin }\end{array}$ \\
\hline Merit & $63 \mu \mathrm{g}$ & 9 & $0.8 \mathrm{mg}$ & $10 \mathrm{mg}$ & USA \\
\hline Marlboro & $155 \mu \mathrm{g}$ & 10 & $1.8 \mathrm{mg}$ & $12 \mathrm{mg}$ & USA \\
\hline Camel & $149 \mu \mathrm{g}$ & 16 & $1.1 \mathrm{mg}$ & $15 \mathrm{mg}$ & USA \\
\hline Sakura & $350 \mu \mathrm{g}$ & 18 & $2.0 \mathrm{mg}$ & $26 \mathrm{mg}$ & Japan \\
\hline
\end{tabular}

Table 2: Aldehyde content cigarettes (US Dept of Health and Service)

\begin{tabular}{|c|c|}
\hline Aldehyde & Amount per cigarette \\
\hline acetalehyde & $1.4 \mathrm{mg}$ \\
\hline crotonaldehyde & $0.2 \mu \mathrm{g}$ \\
\hline formaldehyde & $1.6 \mu \mathrm{g}$ \\
\hline
\end{tabular}


Exposure to ETS whether it is from actively smoking or from second hand exposure is a major cardiovascular risk factor ${ }^{59,60}$. The WHO estimate over 26.5 $\%$ of males and $22.1 \%$ or females in the world actively smoke; while $43 \%$ of the world's children are exposed to second hand smoke ${ }^{61}$. Every year 5 million active smokers die, while 600,000 people exposed to second hand smoke also succumb to smoke related illnesses ${ }^{62}$. Cigarette smoke is associated with endothelial dysfunction, decreased angiogenesis, increased arteriosclerosis and various other cardiovascular diseases ${ }^{18,63,64}$. Nevertheless, the specific chemicals in the tobacco smoke that cause toxicity have not been identified and the mechanisms underlying the cardiovascular toxicity of tobacco smoke remains unclear. The main questions remain what chemical(s) constituents, mechanism(s) and susceptibility factors associated with ETS and environmental pollution can account for increased mortality and decreased cardiovascular health. 


\section{Acrolein}

Acrolein is an unsaturated aldehyde also known as acrylaldehyde, acrylic aldehyde, allyl aldehyde, ethylene aldehyde, 2-propenal, and prop-2-en-1-al. Acrolein at room temperature is a colorless or yellow combustible liquid.

\section{Structure:}<smiles>C=CC=O</smiles>

\section{Empirical formula: $\mathrm{C}_{3} \mathrm{H}_{4} \mathrm{O}$}

Molecular weight: $56.06 \mathrm{~g} / \mathrm{mol}$

Vapor pressure: $274 \mathrm{mmHg}$

Conversion factor: $1 \mathrm{ppm}=2.3 \mathrm{mg} / \mathrm{m}^{3} ; 1 \mathrm{mg} / \mathrm{m}^{3}=0.44 \mathrm{ppm}$

Acrolein is used in industry for the production of plastics, rubber and as an intermediate in the production of acrylic acid. Acrolein is also used as an herbicide, aquacide, slimicide; on farms, in drainage ditches and in paper production. Acrolein is also present in varying concentrations as a result of combustion of organic material (Table 3$)^{65-67}$. Acrolein is highly water soluble and possesses low vaporizing pressure making acrolein a highly mobile substance. In ambient air acrolein ecxist solely in a vapor-phase, and exposure occurs primarily through atmospheric contact. For long-term outdoor pollution studies, government agencies use TO-11A method (active sampling with 2-4 dinitrophynlhydrazine [DNPH] coated solid sorbents). This particular method 
samples air downstream of $\mathrm{KI}$ oxidant scrubbers which then pass on to silica gel cartridges coated with DNPH, DNHP derivatives are analyzed by liquid chromatography (LC) with detection by diode-array, UV-visible spectroscopy. The DNHP method is unstable with humidity, temperature and ozone level fluctuation. This method is used primarily on the west coast and mid-west regions. The most recent and highly stable system for collecting airborne aldehyde and ketone data is the modified passive aldehyde and ketone sampler (PAKs). PAKs method for collection effeciencys is $\sim 100 \%$ for most saturated carbonyls, and $99 \pm 5 \%$ for acrolein even with humidity fluctuations from $30-90 \%$. (Table 4). 
Table 3: Sources and level of acrolein emissions

\begin{tabular}{|l|l|}
\hline \multicolumn{1}{|c|}{ Source } & \multicolumn{1}{|c|}{ Amount } \\
\hline Gas engine exhaust & $0.05-27.7 \mathrm{mg} / \mathrm{m}^{3}$ \\
\hline Diesel engine exhaust & $0.12-0.21 \mathrm{mg} / \mathrm{m}^{3}$ \\
\hline Smoky indoor environment & $2.3-275 \mu \mathrm{g} / \mathrm{m}^{3}$ \\
\hline Residential wood stoves & $0.7-6.0 \mu \mathrm{g} / \mathrm{m}^{3}$ \\
\hline Main stream cigarette smoke (exhaled & $10-140 \mu \mathrm{g} / \mathrm{m}^{3}$ \\
\hline smoke) & \\
\hline Side stream cigarette smoke & $100-1700 \mu \mathrm{g} / \mathrm{m}^{3}$ \\
\hline Total industrial air emissions & \\
\hline Fires (Boston, USA) & $208,108 \mathrm{lbs}$ \\
\hline
\end{tabular}


Table 4: Methods for acrolein sampling and testing. ${ }^{a . b}$

\begin{tabular}{|c|c|c|c|c|}
\hline $\begin{array}{l}\text { Sample } \\
\text { matrix }\end{array}$ & Sample preparation & $\begin{array}{c}\text { Assay } \\
\text { procedure }\end{array}$ & $\begin{array}{l}\text { Limit of } \\
\text { detection }\end{array}$ & Reference \\
\hline \multirow[t]{4}{*}{ Air } & $\begin{array}{l}\text { Adsorb on sorbent coated with 2- } \\
\text { (hydroxymethyl)piperidine on } \\
\text { XAD-2; desorb with toluene; } \\
\text { analyse for oxazolidine derivative }\end{array}$ & GC/NSD & $\begin{array}{c}2 \mu \mathrm{g} / \mathrm{sample} \\
\left(6.1 \mu \mathrm{g} / \mathrm{m}^{3}\right)\end{array}$ & $\begin{array}{l}\text { US OSHA, } \\
\text { 1989; Eller, } \\
1994\end{array}$ \\
\hline & $\begin{array}{l}\text { Draw air through midget impinger } \\
\text { containing acidified DNPH and } \\
\text { isooctane; extract DNPH } \\
\text { derivative with } \\
\text { hexane:dichloromethane ( } 70: 30) \\
\text { solution; evaporate to dryness; } \\
\text { dissolve in methanol }\end{array}$ & $\begin{array}{l}\text { Reversed- } \\
\text { phase } \\
\text { HPLC/UV }\end{array}$ & NR & $\begin{array}{l}\text { US EPA, } \\
1988\end{array}$ \\
\hline & $\begin{array}{l}\text { Draw air through bubblers in } \\
\text { series containing 4- } \\
\text { hexylresorcinol in an alcoholic } \\
\text { trichloroacetic acid solvent } \\
\text { medium with mercuric chloride }\end{array}$ & Colorimetry & $\begin{array}{c}22.9 \mu \mathrm{g} / \mathrm{m}^{3} \\
(10 \mathrm{ppb})^{\mathrm{c}}\end{array}$ & $\begin{array}{c}\text { Feldstein } \\
\text { et al., } \\
1989 a\end{array}$ \\
\hline & $\begin{array}{l}\text { Draw air through midget impinger } \\
\text { containing } 1 \% \text { sodium bisulfite; } \\
\text { react with 4-hexylresorcinol in an } \\
\text { alcoholic trichloroacetic acid } \\
\text { solvent medium with mercuric } \\
\text { chloride }\end{array}$ & Colorimetry & $\begin{array}{l}22.9 \mu \mathrm{g} / \mathrm{m}^{3} \\
(10 \mathrm{ppb})\end{array}$ & $\begin{array}{l}\text { Feldstein } \\
\text { et al., } \\
1989 \mathrm{~b}\end{array}$ \\
\hline Moist air & $\begin{array}{l}\text { Collect in DNPH-impregnated } \\
\text { adsorbent tubes (with calcium } \\
\text { chloride tubes); extract with } \\
\text { acetonitrile }\end{array}$ & HPLC/UV & $\begin{array}{c}0.3 \\
\mu \mathrm{g} / \mathrm{sample} \\
(0.01 \\
\left.\mathrm{mg} / \mathrm{m}^{3}\right)\end{array}$ & $\begin{array}{l}\text { Vainiotalo } \\
\& \\
\text { Matveinen, } \\
1992 \\
\end{array}$ \\
\hline $\begin{array}{l}\text { Exhaust } \\
\text { gas }\end{array}$ & $\begin{array}{l}\text { Derivatize with O-benzyl- } \\
\text { hydroxylamine to O-benzyloxime; } \\
\text { brominate with sulfuric acid, } \\
\text { potassium bromate, and } \\
\text { potassium bromide; reduce with } \\
\text { sodium thiosulfate; extract with } \\
\text { diethyl ether }\end{array}$ & GC/ECD & NR & $\begin{array}{l}\text { Nishikawa } \\
\text { et al., } \\
\text { 1987a }\end{array}$ \\
\hline $\begin{array}{l}\text { Aqueou } \\
\text { s } \\
\text { solution }\end{array}$ & $\begin{array}{l}\text { Derivatize with } 0-(2,3,4,5,6- \\
\text { pentafluorobenzyl)hydroxylamine }\end{array}$ & $\begin{array}{l}\text { MIMS/EIM } \\
\text { S }\end{array}$ & $\begin{array}{l}10 \mu \mathrm{g} / \mathrm{litre} \\
(10 \mathrm{ppb})\end{array}$ & $\begin{array}{l}\text { Choudhury } \\
\text { et al., } 1992\end{array}$ \\
\hline $\begin{array}{l}\text { Rainwat } \\
\text { er }\end{array}$ & $\begin{array}{l}\text { Derivatize with O-methoxylamine } \\
\text { to O-methyloxime; brominate with } \\
\text { sulfuric acid, potassium bromate, } \\
\text { and potassium bromide; reduce } \\
\text { with sodium thiosulfate; elute with } \\
\text { diethyl ether }\end{array}$ & GC/ECD & $0.4 \mu \mathrm{g} /$ /itre & $\begin{array}{l}\text { Nishikawa } \\
\text { et al., } \\
\text { 1987b }\end{array}$ \\
\hline $\begin{array}{l}\text { Liquid } \\
\text { and } \\
\text { solid } \\
\text { wastes }\end{array}$ & $\begin{array}{l}\text { Purge (inert gas); trap in suitable } \\
\text { adsorbent material; desorb as } \\
\text { vapour onto packed gas } \\
\text { chromatographic column }\end{array}$ & GC/FID & $0.7 \mu \mathrm{g} /$ litre $^{d}$ & $\begin{array}{l}\text { US EPA, } \\
1986\end{array}$ \\
\hline
\end{tabular}




\begin{tabular}{|l|l|c|c|c|}
\hline $\begin{array}{l}\text { Biologic } \\
\text { al } \\
\text { samples }\end{array}$ & $\begin{array}{l}\text { Derivatize with DNPH; extract } \\
\text { with chloroform, hydrochloric } \\
\text { acid; dry with nitrogen; dissolve in } \\
\text { methanol }\end{array}$ & HPLC/UV & $1 \mathrm{ng}$ & $\begin{array}{c}\text { Boor \& } \\
\text { Ansari, } \\
1986\end{array}$ \\
\hline
\end{tabular}

a From IARC (1995).

D Abbreviations used: $\mathrm{DNPH}=2,4$-dinitrophenylhydrazine; $E C D=$ electron capture

detection; FID = flame ionization detection; $G C=$ gas chromatography; HPLC/UV = high-performance liquid chromatography/ultraviolet detection; MIMS/EIMS = membrane introduction mass spectrometry/electron impact mass spectrometry; $M S=$ mass spectrometry; $N R=$ not reported; NSD = nitrogen selective detection.

c Note that $1 \mathrm{ppb}=1 \times 10^{-9}$.

d Practical quantification limits for other matrices: $7 \mu \mathrm{g} / \mathrm{litre}$ for groundwater; $7 \mu \mathrm{g} / \mathrm{kg}$ for low-level soil samples; $350 \mu g /$ litre for water-miscible liquid waste samples; $875 \mu \mathrm{gg} / \mathrm{kg}$ for high-level soil and sludge samples; $875 \mu \mathrm{g} /$ litre for non-water-miscible waste samples. 
The EPA reported mean ambient concentrations of acrolein to be $14.3 \mu \mathrm{g} / \mathrm{m}^{3}(6$ ppb) (Table 3) ${ }^{65-67}$.

Not only can we breath in acrolein we can also ingest acrolein, through heating of carbohydrate-containing foods which results in the formation of reactive carbohydrate intermediates that can undergo carbon-carbon cleavage and ultimately produce acrolein ${ }^{68}$. Acrolein is a highly reactive electrophile due to the polarization of the double bond by the aldehyde group. In the body acrolein reacts readily with protein nucleophiles, non-protein sulfhydryl groups, or primary and secondary amines found in nucleic acids. Acrolein is endogenously produced as a by-product of lipid peroxidation and possible mediator in several human diseases, as reviewed by Uchida et al ., ${ }^{69,70}$ Acrolein conjugates readily and rapidly with sulfhydryl groups and is essentially irreversible. This reaction leads to the formation of thiazolidine derivatives and a decrease in glutathione (GSH) stores without an increase in oxidized GSH (GSSG). This pathway results in an acrolein-GSH adduct which is further metabolized by both mitochondrial and cytosolic aldehyde and alcohol dehydrogenase. Ultimately acrolein is excreted in urine as mercapturic acid derivatives, or remains as protein-acrolein adducts within the body (Fig. 1) 67,71 


\section{Figure 1}

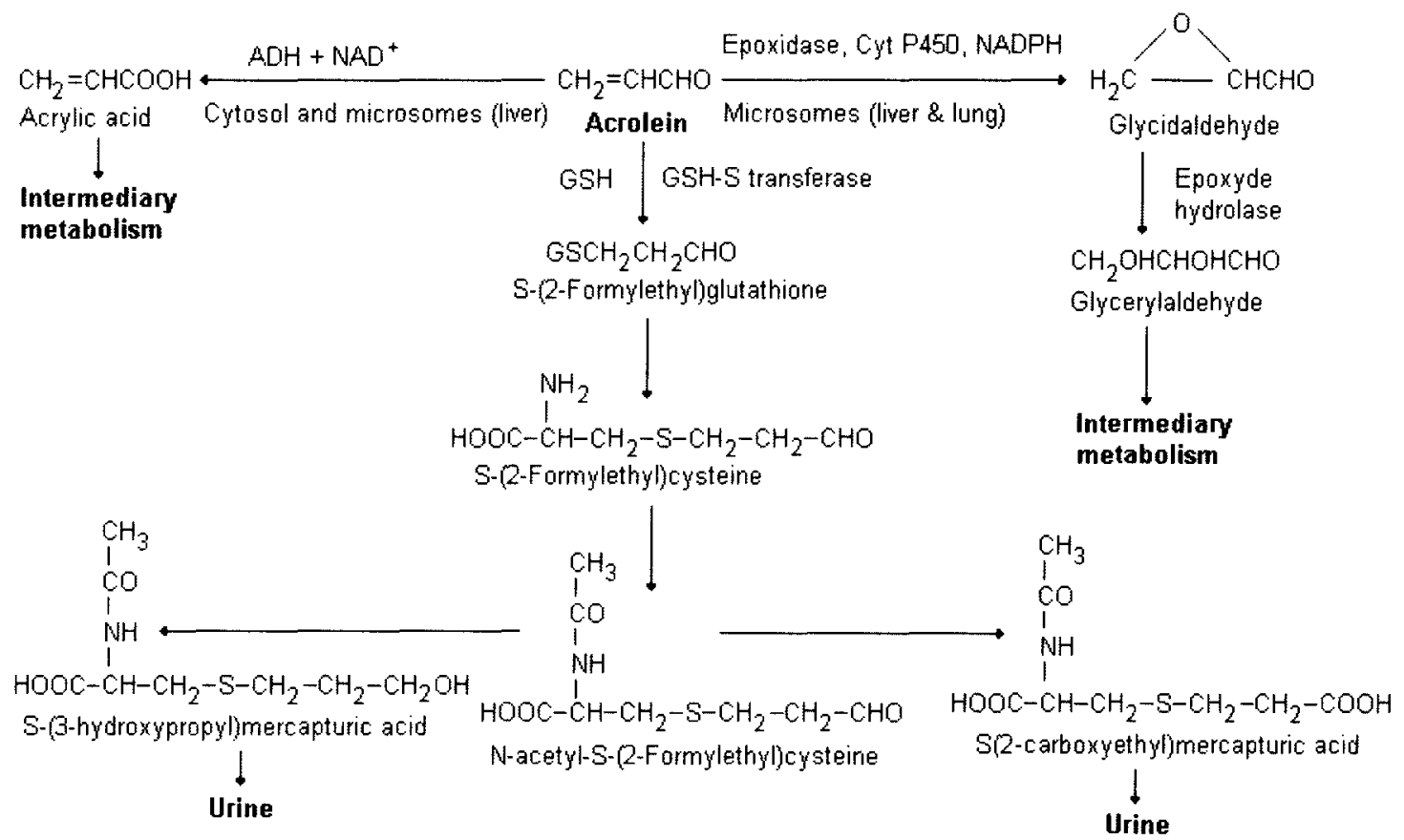


Figure 1 metabolism of acrolein Intermediary metabolism can form Acrylic acid or Glycidaldehyde from acrolein, acrolein can also be excreated in the urine as mercapturic acid derivatives goes through several 
It has been previously shown that administration of radioactive acrolein $(0.82$ $\mathrm{mg} / \mathrm{kg}$ ) to lactating goats, incorporation of the radioactivity appeared to follow incorporation of metabolites into normal biosynthetic pathways of both mother and nursing kid ${ }^{72}$.

Acute exposure to acrolein at levels as low as $0.99 . \mathrm{ppm}$ for $5 \mathrm{~min}$ causes severe eye and nose irritation in humans ${ }^{73,74}$. Lyons et al., ${ }^{75}$ showed in a multi-species study containing fifteen Sprague-Dawley rats (male), seven to eight Princeton or Hartley guinea pigs (male), two pure bred beagle dogs (male); and nine squirrel monkeys (male). All species were exposed to acrolein, $8 \mathrm{hr} /$ day, 5 days/week, for 6 weeks at concentrations of either $0.7 \mathrm{ppm}$ or $3.7 \mathrm{ppm}$. No deaths were reported in the $0.7 \mathrm{ppm}$ group, histopathology of the lungs showed significantly increased inflammation in all species, however inflammation was found to be significantly more chronic in the lungs of more complex organisms; beagles and monkeys. In the $3.7 \mathrm{ppm}$ group, two monkeys died within two weeks after onset of exposure. All species exhibited extensive mucosal gland irritation within the first week which continued throughout the remainder of the study. In histological sections non-specific inflammatory changes were noted in the lungs, liver, and kidney of all species inflammatory changes within the lung were seen in the bronchi rather than the bronchioles. All study groups were found to be significantly different from that of control groups. Data supports acroleins ability to cause extreme tissue inflammation and damage not only in the lungs but can travel to various organs throughout the body and inflammation severity varies 
from species to species. The more complex organisms seemed to be more susceptible to inflammation caused by acrolein inhalations.

Acrolein is classified as an environmental toxicant, the defined OSHA permissible exposure limit is $0.1 \mathrm{ppm}$ per $8 \mathrm{~h} / \mathrm{d}$ (time weighted average;TWA) or $0.3 \mathrm{ppm}$ for $15 \mathrm{~min}$. short term exposure (TWA). Both are near or above acrolein's odor threshold of $0.2 \mathrm{ppm}$.Acrolein can cause disruptions in sulfahydryl groups that are critical for chemical reactions within living cells, leading to disruption of intermediate metabolism, inhibition of cell growth or division, and cell death ${ }^{76}$. Acrolein is a known constituent of environmental tobacco smoke (ETS); ETS promotes arteriosclerosis and endothelial dysfunction by inducing proinflammatory stimuli. The link between cigarette smoke and cardiovascular disease is poorly understood, however due to the abundance, reactivity, and proinflammatory nature, acrolein is a likely candidate ${ }^{77}$. There is a need to further understand acroleins possible role in cardiovascular disease and the link between cigarette smoke. The CDC reports people that smokers are 2-4 times more likely to develop coronary heart disease compared to non-smokers.

\section{Endothelial Progenitor Cells}

Prior to 1997 , angiogenesis was thought to occur only in a neonatal state, as mesodermal cells differentiated into angioblasts, ultimately giving rise to endothelial cells, the process of neovascularization. However, in 1997 Asahara and colleagues revolutionized this dogma with the discovery of $\mathrm{CD} 34^{+}$cell subset 
that possessed an endothelial phenotype. The endothelial like cells were sorted from human blood by magnetic beads and autologous transplants showed these cells had the ability to incorporated into sites of active angiogenesis and were beneficial in wound healing, they coined these cells Endothelial Progenitor Cells (EPCs) $^{78}$

\section{Definition:}

EPCs originate from the bone marrow (BM) and are present in either a quiescent state in the non-vascular niche of the BM or a proliferative state in the vascular niche from which they are mobilized ${ }^{79,80}$. EPCs can be defined by numerous markers in varying combinations, the most accepted is a combination of a stem cell marker along with an endothelial lineage marker. In the initial paper Asahara et. al., human blood was drawn, sorted by magnetic bead for $\mathrm{CD} 34^{+}$and Flk-1 ${ }^{+}$ cells, then stained for CD45, CD34, CD31, Flk-1, TIE-2 and E-Selectin ${ }^{78}$. There are several markers commonly used to discern EPCs from other cells present within the body (Table 5) ${ }^{81,82}$. 
Table 5: Commonly used EPC markers and definition

\begin{tabular}{|c|c|}
\hline Marker & Definition \\
\hline $\begin{array}{l}\text { Vascular Endothelial Growth Factor } \\
\text { Receptor } 2^{+} \\
\text {(VEGFR2, KDR, Flk-1) }\end{array}$ & $\begin{array}{l}\text { Endothelial marker, surface receptor } \\
\text { for VEGF (mouse) }\end{array}$ \\
\hline von Willibrand factor $(\mathrm{vWf})^{+}$ & $\begin{array}{l}\text { Endothelial marker, cell surface } \\
\text { marker bind to Factor VIII, important } \\
\text { for platelet adhesion to wound sites } \\
\text { (mouse) }\end{array}$ \\
\hline $\mathrm{CD}_{4} 4^{+}$ & $\begin{array}{l}\text { Hematopoetic stem cell lineage } \\
\text { marker, important for cell-cell } \\
\text { adhesion (human) }\end{array}$ \\
\hline $\operatorname{Lin}^{-}$ & $\begin{array}{l}\text { Cocktail of antibodies used to } \\
\text { determine cellular lineage (human) }\end{array}$ \\
\hline $\mathrm{CD}^{2} 5^{\text {-dim }}$ & $\begin{array}{l}\text { Surface marker on hematopoetic } \\
\text { cells, protein tyrosine phosphatase } \\
\text { (mouse) }\end{array}$ \\
\hline $\mathrm{CD}^{2} 33^{+}$ & $\begin{array}{l}\text { Also known as Prominin, cell surface } \\
\text { marker of unknown function (mouse) }\end{array}$ \\
\hline Lectin $^{+}$ & $\begin{array}{l}\text { Cell surface sugar binding protein } \\
\text { (mouse) }\end{array}$ \\
\hline${\mathrm{Sca}-1^{+}}^{+}$ & $\begin{array}{l}\text { Stem cells marker-1, glycosyl } \\
\text { phosphatidylinositol-anchored cell } \\
\text { surface protein (mouse) }\end{array}$ \\
\hline C-kit ${ }^{+}$ & $\begin{array}{l}\text { Cytokine receptor, binds to stem cell } \\
\text { factor }\end{array}$ \\
\hline${\mathrm{Tie}-2^{+}}^{+}$ & $\begin{array}{l}\text { Endothelial specific, identified as } \\
\text { Angiopoietin I receptor (mouse) }\end{array}$ \\
\hline $\mathrm{CXCR}^{+}$ & $\begin{array}{l}\text { CXC chemokine receptor, bind SDF- } \\
1 \text { (mouse) }\end{array}$ \\
\hline
\end{tabular}


EPCs are evaluated by surface markers and angiogenic ability when seeded on Mitrigel $($. Angiogenic ability of these cells allow for increased repair of damaged vasculature and improves over all vascular health. Other endothelial properties have been evaluated on EPCs as well such as, NO production which is very important for vasodilation and further EPC homing to sites of injury. It has been shown circulating endothelial progenitor cells account for only $0.01 \%$ of circulating cells. However, three hours after hypoxic injury, circulating EPCs are visibly increased, and by 24 hours they account for $12 \%$ of circulating cells ${ }^{83}$.

\section{Mobilization:}

Found within red bone marrow is a heterogeneous population of cells that make up the stem cell niche, consisting of fibroblasts, osteoclasts, hematopoietic and endothelial cells. The bone marrow stromal cells that line the inside microenvironment of the bone marrow are responsible for providing extrinsic signals that maintain the stem cell niche and regulate the repopulation of stem

cells ${ }^{81,84}$. While attached to the stromal cells, stem cells are maintained in the $G_{0}$ phase of the cell cycle, which is the quiescent non-proliferative phase.

Endothelial progenitor cell mobilization from the bone marrow occurs when cytokines interact between the bone marrow stromal cells and stem cells. This allows stem cells to disengage the bone marrow and pass into the blood stream. Respectively, during hypoxic injury, the Hypoxia Inducible Factor 1- $\alpha$ (HIF1- $\alpha$ ) protein levels increase and cause up regulation of VEGF levels. Bone marrow stromal cells can bind to VEGF and increase production of nitric oxide (NO), NO 
can then increase active-MMP-9 levels. MMP-9 is responsible for cleaving membrane bound kit ligand (mKitL), and thus, increasing the bioavailability of soluble kit ligand (sKitL). After levels of sKitL increase attached endothelial progenitor cells bind sKit and are pushed from a quiescent state into a proliferative state. Studies have concluded EPCs follow SDF-1/CXCR4 axis and gradients within the circulation (Scheme 1) ${ }^{81,84-87}$. 
Scheme 1: Hypoxic injury and mobilization of EPCs from bone marrow

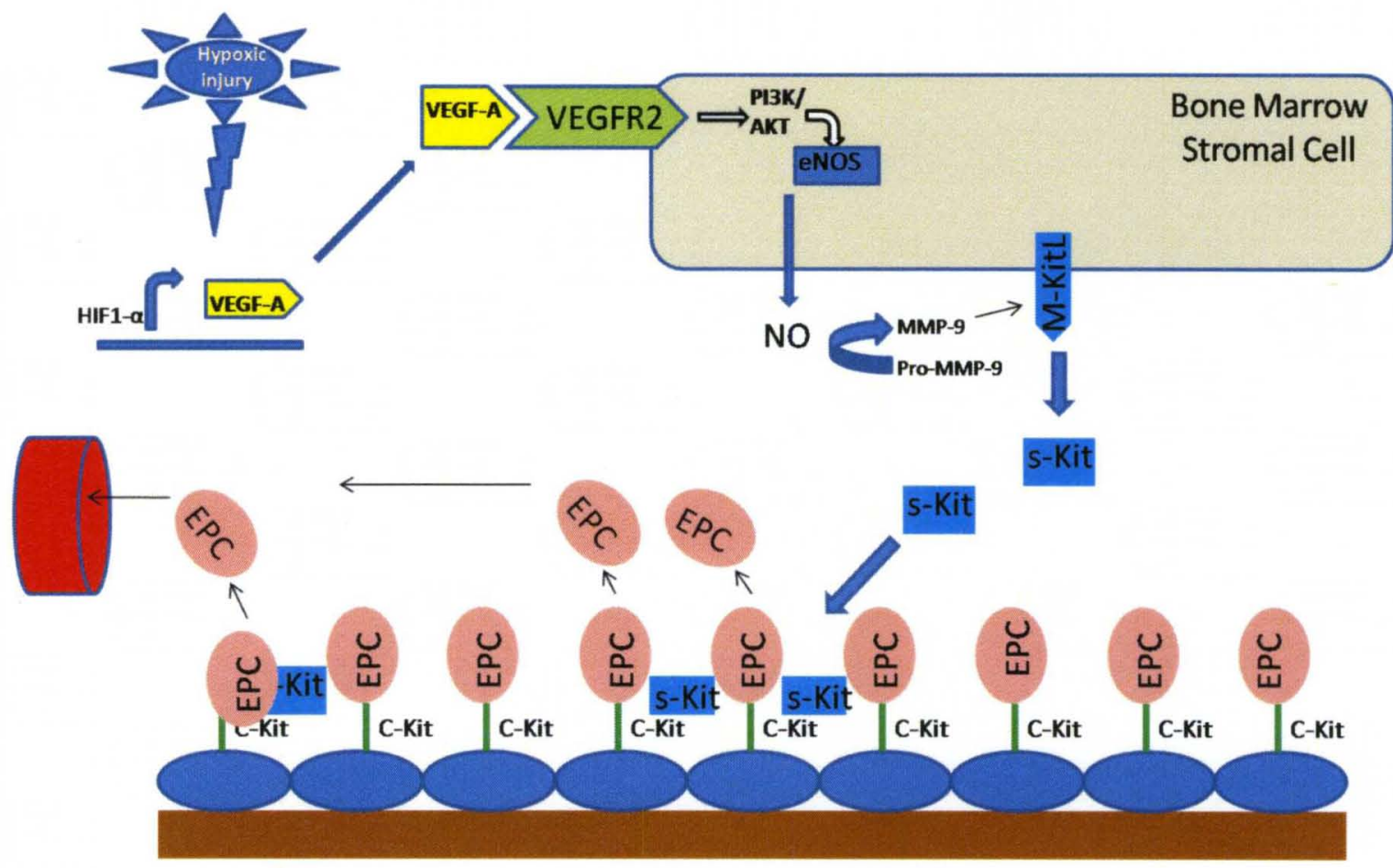




\section{Recruitment/homing:}

Stromal Derived Factor 1 (SDF-1) protein is crucial for homing and recruitment of circulating EPC to sites of injury. SDF-1 has chemotactic activity that controls adult stem cell trafficking and is the ligand for G-protien coupled receptor CXCR4 ${ }^{88}$. EPCs possess CXCR4 receptors and it has been shown local administration of SDF-1 at the sites of injury increases therapeutic neovascularization $^{89}$. With injury to the endothelium VEGF levels steadily increase along with numerous other cytokines and chemokines. Various stimuli promote mobilization and recruitment of EPCs to sites of injury ${ }^{90}$. Once circulating EPCs come into contact with the appropriate recruitment stimulus, surface adhesion factors are thought to be upregulated and help with cell recruitment and cell adhesion (Table 6) ${ }^{90-97}$. 
Table 6: EPC homing factors

\begin{tabular}{|c|c|c|}
\hline $\begin{array}{l}\text { Chemokine/ receptor } \\
\text { and integrins }\end{array}$ & Cell type and markers & Animal model (species) \\
\hline SDF-1/ CXCR4 & EPC, CD34+ & $\begin{array}{l}\text { Hind limb ischemia } \\
\text { (Murine) }\end{array}$ \\
\hline IL-8 /CXCR2 or CXCR1 & $\mathrm{CD}^{4} 4^{+}$ & $\begin{array}{l}\text { Myocardial infarction } \\
\text { (Murine) }\end{array}$ \\
\hline HMGB-1 & EPC & $\begin{array}{l}\text { Myocardial infarction } \\
\text { (Murine) }\end{array}$ \\
\hline$\beta 2$-integrin & $\mathrm{EPC}$ & $\begin{array}{l}\text { Myocardial infarction, } \\
\text { Hind limb ischemia } \\
\text { (Murine) }\end{array}$ \\
\hline E- and P-Selectin & EPC & $\begin{array}{l}\text { Tumor, Hind limb } \\
\text { ischemia } \\
\text { (Murine) }\end{array}$ \\
\hline
\end{tabular}




\section{Transmigration:}

EPC transmigration is similar to leukocyte rolling and transmigration. In Vitro studies have lead to evidence suggesting once the EPC has made contact with or near the injured tissue, low affinity contacts are made between selectins present on the cell surface and the vascular wall, much like the process seen with leukocyte rolling ${ }^{98}$. The integrin, E-selectin, is important to not only homing but actually regulating the bone marrow-derived EPC recruitment to sites of injury. After cell rolling, further adhesion occurs through $\beta 2$-integrins ${ }^{99}{ }^{100}$. For firm adhesion $\alpha 4 \beta 1$ integrins and LFA-1 increase adhesiveness via their respective ligands, VCAM-1 and I-CAM-1. After rolling and firm adhesion, EPCs must transmigrate, however, little is known about the true mechanism behind this process. It is postulated that PECAM-1 and CD99 play a role in transmigration of EPCs (Scheme 2) ${ }^{101}$. 
Scheme 2: EPC adhesion and transmigration

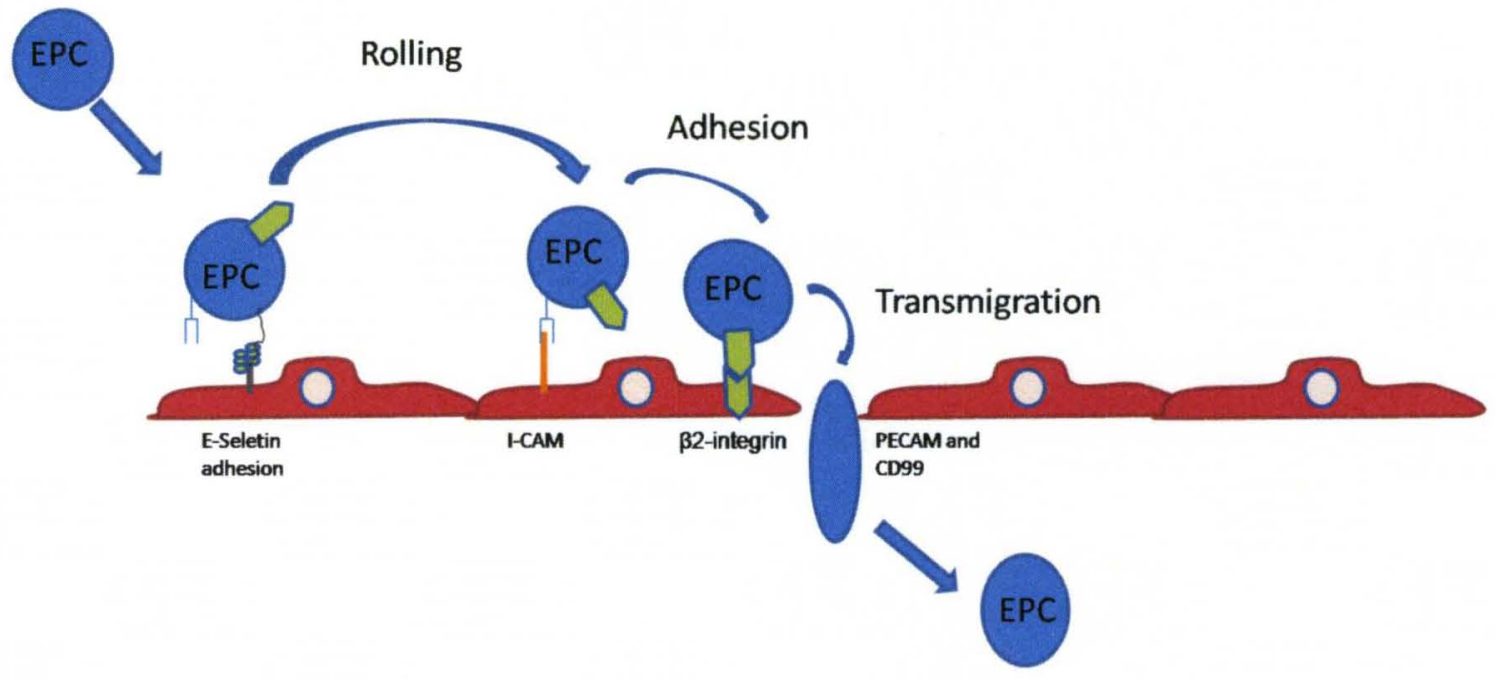




\section{Differentiation:}

After activation and mobilization into the circulation, EPCs start maturing and eventually loose stem cell markers and characteristics while simultaneously acquiring more mature endothelial cell characteristics ${ }^{102}$. In previous studies it has been shown phospho-Akt is induced in the ischemic muscle by cytokines such as VEGF and SDF-1, which are secreted by skeletal muscle cells, stromal cells, and endothelial cells in response to ischemia. In particular, the phosphorylation of Akt in endothelial cells leads to entrapment of systemically administered ex vivo-expanded EPCs into the ischemic muscle through various kinds of mechanisms, overexpression of ICAM-1 on endothelial cells (ECs) and the increased incorporation and transendothelial migration of EPCs ${ }^{103}$. In order to study actual incorporation, EPCs were isolated and tagged with diacyl-LDL then injected into nude mice. Histology sections were taken of ischemic muscle and $56 \pm 4.7 \%$ of the vessels had EPC incorporation out of the 16 section evaluated $(10 X \text { field })^{103}$. While still other studies using the same approach show only $0.01 \%$ of EPCs injected going to the site of injury and actively participate in angiogenesis ${ }^{104}$. Various studies report different incorporation numbers for EPCs at the sites of injury, this could be accounted for by the methods used and the analysis of data. There is are small amounts of EPCs in the circulation even after ischemic injury and so far histology and rudimentary counting has been the main published method, a lot could be missed or over counted by this approach just due to human error or bias. 
When incorporated into the site of injury, EPCs act in a paracrine fashion releasing growth factors such as VEGF and stimulating release of NO, thus stimulating the release of growth factors from surrounding adult endothelial cells. The growth factors released recruit more EPC to the site of injury and other pro-angiogenic cells such as macrophages. The immature EPCs soon fully differentiate into mature endothelial cells, after exposure to growth factors such as VEGF, SDF-1, IGF-1, and HGF in the surrounding environment ${ }^{91,105-108}$.

\section{Non-Bone Marrow, Endothelial Progenitor Cell Niches}

EPC can also be found in resident tissue niches outside of the bone marrow. Stem cell niches provide a balance between quiescence and activity of the stem cell by protecting them from differentiation stimuli, apoptotic stimuli, and other stimuli that could challenge stem cell reserves. A stem cell niche is defined by functional dimensions and anatomical dimensions which specifically enable stem cells to asymmetrically reproduce and allow for self renewal ${ }^{109-111}$. Stem cells within a niche are embedded in a 3-D extra cellular matrix (ECM). The ECM can be divided into two groups, structural proteins and proteoglycans (PGs), including glycosaminoglycans (GAGs), which are primarily responsible for regulatory processes in disease and development. The ECM of the stem cell niche consists mainly of basement membrane components, such as collagens, laminins, fibronectin, and GAGs. Integrins connect the ECM niche to the internal cytoskeleton of the stem and progenitor cells and they transmit external signals directly to the stem cells. When mechanical force is applied to the ECM, this 
influences the integrins and impacts stem cell fate by activation of various signaling pathways. Within each niche, some ECM proteins have specialized functions restricted to distinct stem cell niches ${ }^{112}$. For example, $\beta-1$ integrins are predominately expressed within epidermal stem cell niches while tenascin c and osteopontin are specifically present in hematopoietic stem cell niches. Some investigators have suggested that bone marrow is the only source of stem/progenitor cells, however when the body depletes the bone marrow stem cells, non-bone marrow stem cell niches are called upon and play a vital role and help repair damaged tissues ${ }^{113}$. Non-bone marrow niches are found throughout the body some are better documented and studied than others. It is thought that niches are formed during embryogenesis and stem cell migrations during fetal tissue development and are actually maintained into adulthood ${ }^{114,115}$.

The spleen contains two distinct areas known as the red and white pulp, the red pulp contains macrophages that filter out debris and dead cells from the circulation. The white pulp or "lymphoid compartment" synthesizes antibodies against invading pathogens and releases platelets and nuetrophils in response to bleeding and infections ${ }^{116-118}$. However, aside from these functions the spleen is the site of extramedullary hematopoiesis. In times of stress and disease when bone marrow cannot fulfill the demand for new cells, the spleen acts as a secondary hematopoietic center ${ }^{118}$. This is not surprising since the spleen is a site of hematopoiesis during gestation ${ }^{104}$. Recent studies have shown cells with multi-lineage capability are found within the spleen and the spleen has been recognized not just as a secondary center for hematopoiesis but also a storage 
site for multiple stem cell lineages. Many studies have linked this to a developmental origin called the aorta-gonad-mesonephros (AGM) ${ }^{119}$. The AGM region is the first site for hematopoiesis, which then migrates to the liver and spleen, until ultimately the bone marrow takes over as the primary site of hematopoiesis $^{120,121}$. Recent studies have shown the AGM has a broader cell lineage potential than just producing CD45+ hematopoietic cells. When CD45cells were harvested from the AGM region of mice expressing green fluorescence protein (GFP) and transplanted into the liver of neonatal mice ${ }^{122-}$ ${ }^{124}$, the transplanted cells were found not only in the bone marrow and spleen but also non-hematopoietic tissue as well- liver, kidney, lung, small intestine, vascular wall and uterus ${ }^{125-131}$. Literature suggests that stem cells with multilineage potential are found in the spleen as a result of early migration pattern from the AGM region [ref]. This leads to the idea of how niches could be formed not just within the spleen but various locations in the body due to early gestational development and stem cell migrations along developmental axis ${ }^{122,}$ ${ }^{132}$. It is currently believed that tissue-specific progenitor cells reside within niches proximal to the cells types they will regenerate.

Recent studies have led to the identification of several EPC niches in the spleen, liver, adipose tissue, adventitial tissue, and small intestine ${ }^{125-131}$. Using a parabiosis model coupled with a reverse bone marrow transplant and hindlimb ischemia, Aicher et al., ${ }^{99}$ set out to discern the actually percentage of EPC that come from non-bone marrow niches. In this study $74 \pm 13 \%$ of circulating progenitor cells are non-bone marrow derived and incorporated into hindlimb 
ischemia (HLI) of rats. In addition as previously mentioned organs such as the liver and small intestine have a considerable number of resident progenitor cells, within progenitor cell niches. Sex-mismatched transplant of liver and small intestine of rats followed by the induction of $\mathrm{HLI}$, showed that $4.7 \pm 3.7 \%$ small intestine-derived endothelial progenitors incorporated in the ischemic tissue of HLI models and contributed to vasculogenesis, while the liver contributed $6.3 \pm$ $2.2 \%{ }^{133}$. Within the adipose tissue, there is the stromal vascular fraction (SVF). This fraction has angiogenic capacity equivalent to that of bone marrow-derived EPCs when injected after $\mathrm{HLI}^{134}$., Other studies have shown that the lung and skeletal muscle also possess endothelial progenitor cell niches. However, it is unclear whether these cells are truly tissue -resident or whether they are derived from the bone marrow ${ }^{131,135}$. Vascular tissue itself has also -been studied and a "vasculogenic zone" was has been recently discovered. This zone lies between the adventitial and media of the vessel wall ${ }^{126}$. Cells within this vasculogenic zone have been identified as CD34+/Tie2+/KDR+/NE-Cadherin+, capable of differentiating into mature endothelial cells and form capillary like sprouts in Mitragel ${ }^{126}$.

Hill et al., ${ }^{136}$ performed a series of experiments with male patients who had varying degrees of cardiovascular risk but had no history of cardiovascular disease. Peripherial blood was taken and EPC numbers were significantly reduced in patients with elevated cholesterol levels, hypertension and diabetics. They also found a significant inverse correlation between EPC numbers and Framingham scores of these patients. EPC depletion could be a by-product of 
increased oxidative stress or other physiologic process within the patient. However, this decrease could also be due to continuos endothelial injury and EPC exhaustion compounding the risk for developing cardiovascular diseases. Previous studies have also shown that a decrease of circulating stem cells can be an important determinant of age-related conditions ${ }^{136}$. Injection of EPC into the circulation of ischemic asythmic models shows a striking result, animals have increased limb salvage and increased angiogenesis of the ischemic leg ${ }^{137}$.

By studying how pollutants affect EPCs we may be able to understand their mechanism of cardiovascular toxicity and to assess the cardiovascular disease risk due to pollutant exposure.

\section{Goals of the project}

The overall thesis of the work presented here is that exposure to environmental pollutants such as acrolein could deplete EPC levels or interfere with EPC mobilization, and thereby increasing the risk of developing cardiovascular disease and endothelial dysfunction. Although EPCs express high levels of manganese superoxide dismutase (MnSOD) and therefore are likely to be resistant to oxidative injury, recent studies have shown that exposure to tobacco smoke or the cardiovascular disease decreases EPC levels . Nevertheless, the mechanisms by which EPC levels are decreased under these conditions remain completely unknown.. Hence, the aim of this project was to examine how inhalation exposure to a ubiquitous environmental pollutant such as 
acrolein affects circulating EPC levels (Aim 1) and to understand the mechanism by which acrolein inhalation affects EPC mobilization (Aim 2). To assess the functional significance of the effects of acrolein on EPCs, I also studied how exposure to this aldehyde affects EPC mobilization after hind-limb (Aim 3). The main purpose of these studies was to learn more about the mechanisms of cardiovascular toxicity due to acrolein exposure. 


\section{CHAPTER II:}

\section{ACROLEIN INHALATION DECREASES CIRCULATING LEVELS OF ENDOTHELIAL PROGENITOR CELLS}

\section{Introduction}

Several epidemiological studies show that exposure to combustion products increases the risk of developing cardiovascular disease. In many large population-based studies, long-term exposure to traffic-generated combustion products has been found to be associated with an increased risk for coronary heart disease ${ }^{138}$, atherosclerosis ${ }^{139}$ and fatal myocardial infarction ${ }^{140}$. Likewise, exposure to products of wood or coal combustion is linked to increases in blood pressure and cardiovascular mortality ${ }^{141,142}$. Moreover, individuals such as bus drivers ${ }^{143}$, chimney sweeps ${ }^{144}$ and firefighters ${ }^{145}$, who are repeatedly exposed to combustion products, have significantly higher rates of cardiovascular mortality than the general population. In addition, extensive data show that cardiovascular disease and mortality are increased by exposure to combustion products generated during smoking ${ }^{146}$ or present in secondhand tobacco smoke ${ }^{147}$. Experimental data with humans or animals exposed to automobile exhaust ${ }^{148}$ or tobacco smoke $\mathrm{e}^{146,147}$ support these epidemiologic findings. These studies suggest that combustion products induce adverse cardiovascular effects. 
Nonetheless, the chemicals that mediate the cardiovascular toxicity of combustion products are unidentified.

Combustion of organic material results in the generation of a complex chemical mixture. The composition of this mixture varies with the source; however, one of the chemicals common to all combustion sources is acrolein. It is produced in high amounts during combustion of organic material in any form (coal, wood, paper, cotton, gasoline, diesel or tobacco) ${ }^{149}$. Recent estimates show that high levels of acrolein (between $6-8 \mathrm{ppm}^{150}$ ) are present in exhaust gases from petrol and diesel engine vehicles, and tobacco smoke (100-600 $\mu \mathrm{g} /$ cigarette $)^{151}$ generates up to $50-70 \mathrm{ppm}$ acrolein. Acrolein is a highly reactive and toxic chemical, ${ }^{76,152}$ which could account, at least in part, for the cardiovascular toxicity induced by combustion products. Our previous studies showed that acrolein inhalation leads to endothelial dysfunction in susceptible mice $^{153}$. Endothelial injury is also an early and integral feature of the cardiovascular toxicity of automobile exhaust ${ }^{148}$, tobacco ${ }^{146,147}$ and wood smoke ${ }^{154}$ exposures. However, mechanisms by which these exposures affect endothelial health remain unclear. Recent work suggests that endothelial repair and regeneration depends, in part, upon circulating cells with pro-angiogenic potential ${ }^{86}$. These cells with pro-angiogenic potential have been coined Endothelial progenitor cells (EPCs) and are also known as Flk/Sca+ cells, they possess both endothelial markers and stem cell markers. The blood level of Flk$1^{+} / \mathrm{Sca}-1^{+}$cells is a sensitive index of endothelial health and is inversely correlated with cardiovascular disease risk ${ }^{86}$. This current study was, therefore, 
designed to test the hypothesis that acrolein exposure adversely affects the number and mobilization of circulating $\mathrm{Flk}-1^{+} / \mathrm{Sca}-1^{+}$cells.

\section{Methods}

\section{Acrolein Exposure}

Acrolein atmospheres were generated from liquid acrolein (Sigma-Aldrich, St. Louis, $\mathrm{MO}, \mathrm{USA} ; \geq 90 \%$; diluted in $\mathrm{dH}_{2} \mathrm{O}, 1: 10$ ). Acrolein exposure was performed using a custom vapor system (Teague Enterprises, Inc., Woodland, CA, USA) with a primary chamber as a constant source, and acrolein vapors diluted with HEPA-filtered room air in a secondary chamber. During exposure, acrolein concentration was continuously monitored using an in-line photo ionization detector (ppb RAE+, Rae Industries, Sunnyvale, CA, USA) upstream of the cage insert vapor delivery unit (Teague Enterprises, Inc.) mounted on a standard polycarbonate rat cage $(41 \mathrm{~cm} \times 34 \mathrm{~cm} \times 21 \mathrm{~cm} ; \approx 31 \mathrm{~L})$. Air or acrolein was distributed through a fine mesh screen at $3 \mathrm{lpm}$ by delivery units with a cyclone-type top that distribute air within $10 \%$ of the mean concentration at six locations in the cage (Scheme 3). Exposure cages were placed partially over heating pads $\left(\approx 22^{\circ} \mathrm{C}\right)$ to allow mice to select preferable temperature. Mice were exposed to $5 \mathrm{ppm}$ acrolein for 2 or $6 \mathrm{~h}(5010 \pm 49 \mathrm{ppb}$ of 2 different exposures) or to $1 \mathrm{ppm}$ acrolein for 4 days $(1,053 \pm 22 \mathrm{ppb}$ of 5 different exposures) (Scheme 4). 
Scheme 3: acrolein inhalation setup

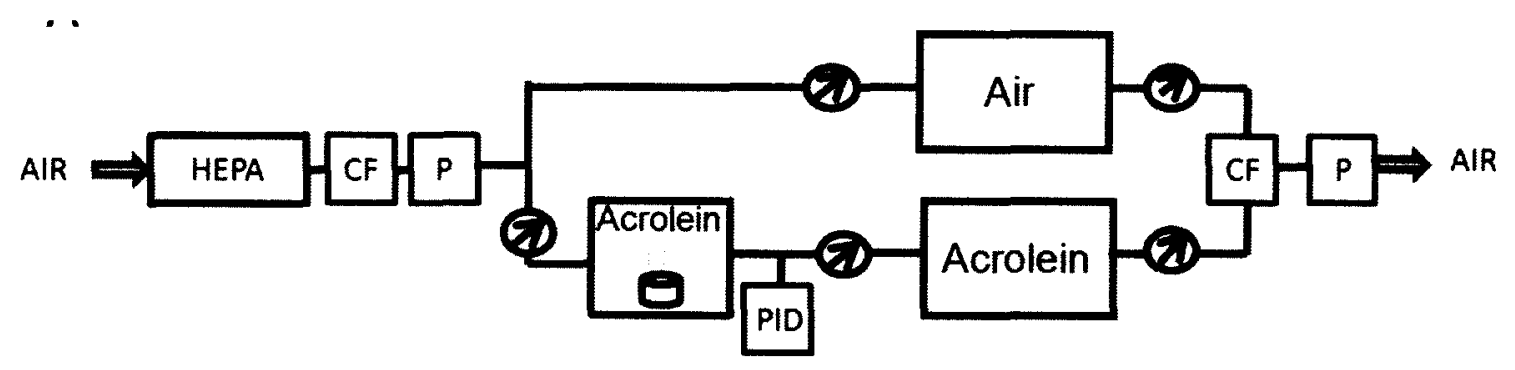


Scheme 4: 1ppm acrolein exposure level stability

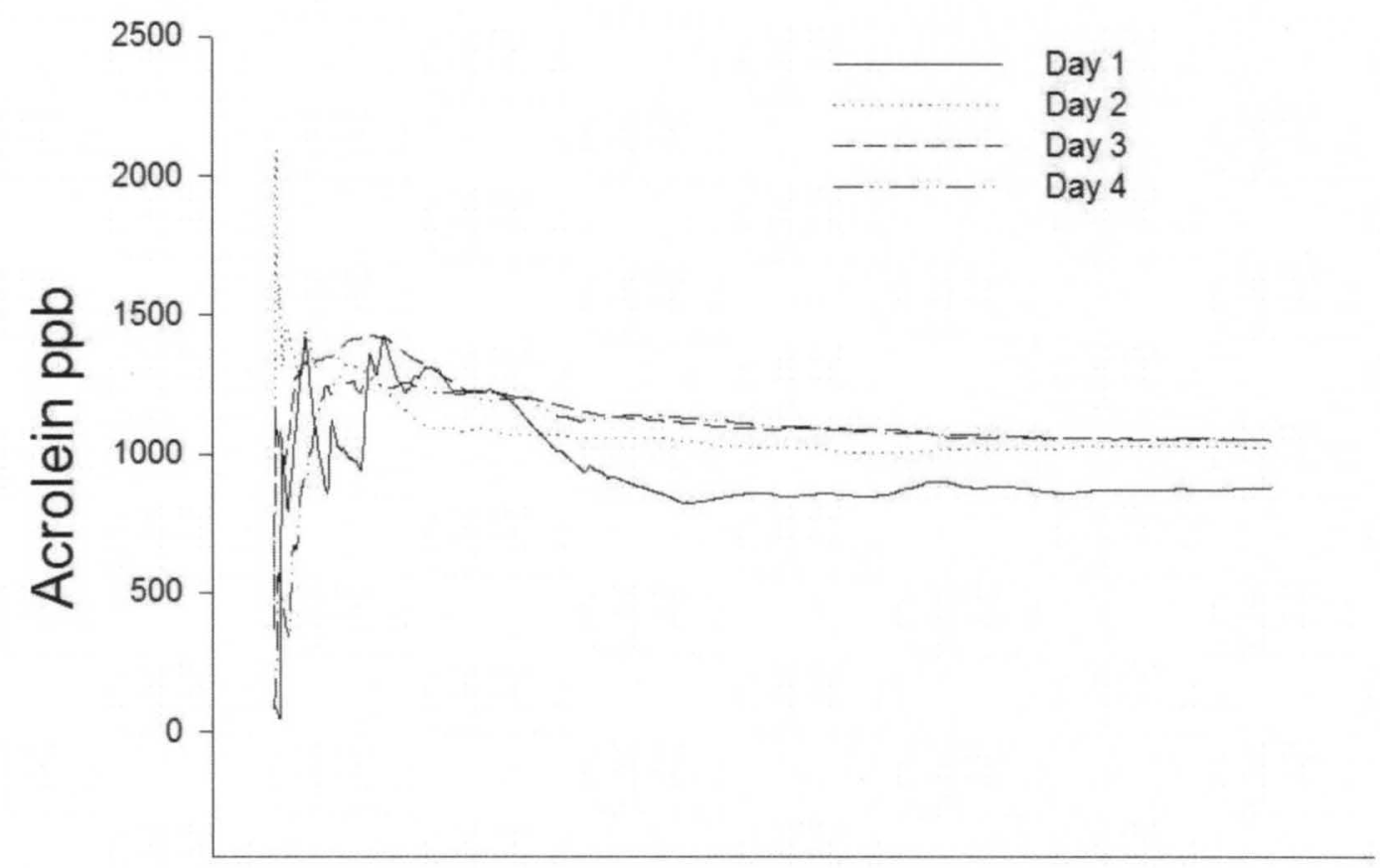

Time 


\section{Circulating endothelial progenitor cell mobilization}

Acrolein (1ppm 6hr/4d) and Air (HEPA air 6hr/4d) exposed mice were injected with saline of VEGF 165 for 4 consecutive days. Immediately after the final exposure, VEGF-injected mice received the CXCR4 antagonist, AMD3100, and control mice received saline. Mice were the euthanized $1 \mathrm{hr}$ after AMD3100 or saline injection (Scheme 5). 
Scheme 5: VEGFIAMD3100 treatment regime

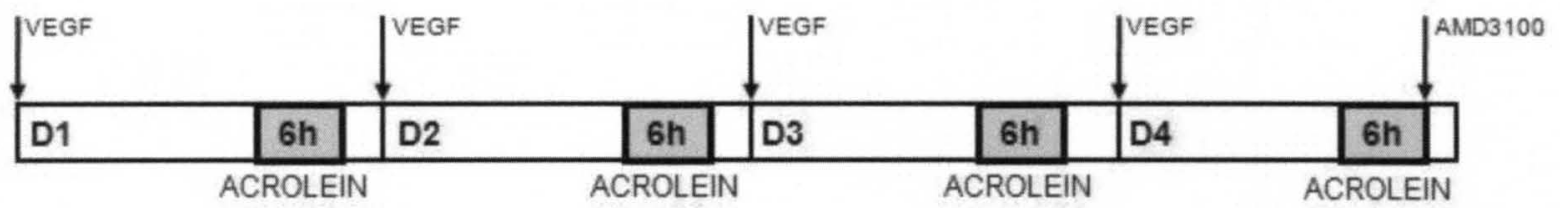




\section{Peripheral blood mononuclear cells and flow cytometry}

Whole blood (300-400 $\mu \mathrm{l}$ ) was lysed (4 ml; BD PharmLyse, BD BioSciences, San Jose, CA, USA; $10 \mathrm{~min}, \mathrm{RT}$ ) and after centrifugation ( $5 \mathrm{~min}, 400 \times \mathrm{g}, \mathrm{RT})$, the supernatant was aspirated and the lysing/centrifugation/aspiration steps were repeated. The cell pellet was resuspended in 1\% FBS/PBS and divided into 2 equal fractions. One fraction was fluorescently-labeled with anti-Sca-1 and antiFlk-1 antibodies tagged with FITC (Fluorescein Isothiocyanate) and APC (Allophycocyanin), respectively. Following centrifugation (5 min, 400xg, RT), mononuclear cells were re-suspended in $1 \%$ FBS/PBS $(20 \mu l)$ with murine CD16/CD32 Fc Block to prevent non-specific binding to cell surface markers $(0.5$ $\mu \mathrm{g}$; BD Biosciences) and incubated for $10 \mathrm{~min}$ on ice. The FITC-Sca-1 (1 $\mu \mathrm{g}$; BD BioSciences) and APC-Flk-1 (1 $\mu \mathrm{g}, \mathrm{BD}$ BioSciences) antibodies or appropriate isotype controls $(1 \mu \mathrm{g} ; \mathrm{BD}$ BioSciences) were added to cells $(23 \mu \mathrm{l})$ and incubated for $30 \mathrm{~min}$ on ice. Cells were then washed with $1 \%$ FBS/PBS $(400 \mu \mathrm{l})$ and centrifuged (5 min, $400 \mathrm{xg}, \mathrm{RT}$ ). Cells re-suspended in 1\% FBS/PBS $(400 \mu \mathrm{l})$ were analyzed using a LSRII flow cytometer (BD BioSciences). Based on forward and side scatter, small non-debris events in a sub-lymphocyte population (3-5 $\mu \mathrm{m}$; sized using fluorescent beads, BD Biosciences) were gated electronically and displayed in a two-color dot plot. Data were subsequently analyzed using FACSDiva v6.0 software (BD Biosciences), and double positive events were normalized per 50,000 events or per $\mu$ of assay volume. Preliminary flow cytometry data indicated that $\geq 98 \%$ of circulating Flk $-1^{+} / \mathrm{Sca}-1^{+}$ cells were also $\mathrm{CD}_{4}{ }^{+}(1 \mu \mathrm{g}$, PerCP-CD45; BD Biosciences). 


\section{Endothelial progenitor cell characterization}

For better characterization EPCs were mobilized. Mice were injected with saline or VEGF 165 saline $(100 \mu \mathrm{g} / \mathrm{kg} / \mathrm{d}$; Peprotech, Inc., Rocky Hill, NJ, USA) $(n=4,4)$ daily for 4 consecutive days, on the $5^{\text {th }}$ day received CXCR4 antagonist, AMD3100, and control mice received saline (5mg/kg, i.p., $100 \mu$; Sigma-Aldrich) $(n=4,4)$. Mice were euthanized $1 \mathrm{~h}$ after AMD3100 or saline injection. Whole blood (1mL) was lysed (9 ml; BD PharmLyse, BD BioSciences, San Jose, CA, USA; $10 \mathrm{~min}, \mathrm{RT}$ ) and after centrifugation (5 min, 400xg, RT), the supernatant was aspirated and the lysing/centrifugation/aspiration steps were repeated. After washing cells were resuspended in 2\% FBS/PBS with FcBlock for staining. All staining antibodies were purchased from eBioscience (San Diego). The following antibodies were used for analysis in three different groupings: Stem cell marker panel 1: Anti-Mouse CD150 FITC, Anti-Mouse Ly-6A/E (Sca-1) PE, Anti-Mouse CD115 (c-fms) PerCP-eFluor® 710, Anti-Mouse CD48 PE-Cy7, Anti-Mouse CD309 (FLK1) APC, Anti-Mouse CD11b APC-eFluor® 780, Anti-Mouse CD34 eFluor® 450, Anti-Mouse CD38 Biotin-Streptavidin 605 nanocrystal; Stem cell marker panel 2: Anti-Mouse CD133 (Prominin-1) Biotin 605, Anti-Mouse CD150 FITC, Anti-Mouse Ly-6A/E (Sca-1) PE, Anti-Mouse CD115 (c-fms) PerCPeFluor ${ }^{\circledR}$ 710, Anti-Mouse CD48 PE-Cy7, Anti-Mouse CD309 (FLK1) APC, AntiMouse CD11b APC-eFluor $\circledast 780$, Anti-Mouse CD34 eFluor $@ 450 ;$ T and B-cell marker panel 3: Anti-Mouse CD8a PerCP-Cy5.5, Anti-Mouse CD3 APC-eFluon 780, Anti-Human/Mouse CD45R (B220) eFluor $(450$, Anti-Mouse CD4 eFluor $\circledast$ 605NC, Anti-Mouse CD31 (PECAM-1) FITC, Anti-Mouse Ly-6A/E (Sca-1) PE, 
Anti-Mouse CD309 (FLK1) APC, and Anti-Mouse CD19 PE-Cy7. Cells were analyzed by flow cytometry (BD LSRII, BioSciences) and data were analyzed using FlowJo (TreeStar Software; Ashland Oregon).

\section{Isolation and culture of bone marrow-derived cells (BMDCs)}

Bone marrow was aspirated from femur and tibia of both legs with $1 \mathrm{~mL}$ HBSS (Clonetics/Lonza, Walkersville, MD, USA), and mononuclear cells were separated by Ficoll gradient centrifugation (Ficoll-Paque PREMIUM, GE Healthcare, Piscataway, NJ, USA; $400 \times g, 20 \mathrm{~min}, 4^{\circ} \mathrm{C}$ ). Trypan blue-viable cells $\left(2-4 \times 10^{6}\right.$ cells per mouse) were isolated and $8 \times 10^{5}$ cells were seeded on fibronectin-coated, 8-well chamber slides (10\% human fibronectin, SigmaAldrich) in $500 \mu \mathrm{L}$ endothelial basal media (Clonetics/Lonza) supplemented with 20\% FBS (Invitrogen, Carlsbad, CA, USA), human endothelial growth factor (hEGF), hydrocortisone, gentamycin/amphotericin $B(G A)$ and bovine brain extract (BBE)(SingleQuot $\circledast$, Clonetics/Lonza) under standard cell culture conditions $\left(37^{\circ} \mathrm{C}, 5 \% \mathrm{CO}_{2}\right)^{155}$. On day 7 , cells were incubated with Dil-acLDL $(2.4 \mu \mathrm{g} / \mathrm{mL}$, Invitrogen $)$ in media for $3 \mathrm{~h}$. After media was removed, cells were washed three times with PBS, fixed in $4 \%$ PFAPBS ( $\mathrm{pH} 7.4$; RT) for $10 \mathrm{~min}$, and then incubated with FITC-UE-lectin $\left(50 \mu \mathrm{g} / \mathrm{mL}\right.$, Sigma-Aldrich) at $37^{\circ} \mathrm{C}$ for 30 min. For labeling of Flk-1 and Sca-1, cells were incubated with FITC-Sca-1 (1:25; BD BioSciences) and APC-Flk-1 (1:15, BD BioSciences) antibodies for $1 \mathrm{~h}$ at RT. Cells were washed three times with PBS before slides were stained with DAPI- 
containing Slow Fade ${ }^{\circledR}$ Gold anti-fade reagent (Invitrogen). Dil-acLDL and FITCUE-lectin double-positive cells were counted in 10 random fields.

\section{Blood counts and plasma biochemistry}

After select exposures, $100 \mu \mathrm{l}$ of blood were used for complete blood count analysis (CBC; Hemavet 500, Coulter Counter, Oxford, CT). Plasma total, HDL and LDL cholesterol, triglycerides, total protein, albumin (Cholesterol CII Enzymatic Kit; L-Type TG-H Kit; Bradford reagent, bromocresol green, Wako, Richmond, VA, USA), ALT, AST (Infinity, ThermoElectron, Louisville, CO, USA), CK and LDH (Promega, Madison, WI, USA) levels were measured using commercially available assay reagents as indicated. Assays were performed using calibrated standards in 96-well plates or using a Cobas Mira Plus 5600 Autoanalyzer (Roche, Indianapolis, IN, USA). Plasma NO ${ }_{x}$ level (stable NO metabolites, nitrate and nitrite; $25 \mu \mathrm{l}$ ) was measured fluorimetrically according to manufacturer's instructions ( $\mathrm{NO}_{\times}$kit; Calbiochem, Darmstadt, Germany).

\section{Isolated aorta studies}

Thoracic aorta were isolated and tested for intact VEGF signaling. Isolated aortas were incubated in autologous plasma and exposed to VEGF $_{165}$ for $15 \mathrm{~min}$ before freezing. 


\section{Vascular reactivity}

Thoracic aortas were isolated and vascular reactivity was assayed as described previously ${ }^{11}$. Briefly, one 3-4-mm ring per mouse was hung on stainless steel hooks in 15-ml water-jacketed organ baths in physiological salt solution (PSS) bubbled with $95 \% \mathrm{O}_{2}$ and $5 \% \mathrm{CO}_{2}$ at $37^{\circ} \mathrm{C}$. The composition of PSS was (in $\mathrm{mM}): \mathrm{NaCl}, 130 ; \mathrm{KCl}, 4.7 ; \mathrm{MgSO}_{4} \cdot 7 \mathrm{H}_{2} \mathrm{O}, 1.17 ; \mathrm{KH}_{2} \mathrm{PO}_{4}, 1.18 ; \mathrm{NaHCO}_{3}, 14.9$; $\mathrm{CaCl}_{2}, 2.0 ;$ glucose, $5.0 ; \mathrm{pH} 7.4$. Rings ( $\approx 1 \mathrm{~g}$ loading tension) were contracted with $100 \mathrm{mM}$ potassium solution ( 2 times) followed by cumulative concentrations of phenylephrine (PE; $0.1 \mathrm{nM}-10 \mu \mathrm{M})$. PE-precontracted rings were relaxed with cumulative concentrations of acetylcholine (ACh; $0.1 \mathrm{nM}-10 \mu \mathrm{M})$ or of sodium nitroprusside (SNP; $0.1 \mathrm{nM}-10 \mu \mathrm{M}$ ) to measure endothelium-dependent or -independent relaxation, respectively. Vessel contraction was quantified as $\mathrm{mg}$ tension, active stress (in $\mathrm{mN} / \mathrm{mm}^{2}$ ) or normalized as percentage of the maximum PE contraction. Relaxation was calculated as percentage reduction of $\mathrm{PE}$-induced tension. The effective concentration producing $50 \%$ response $\left(\mathrm{EC}_{50}\right)$ was assessed by normalizing cumulative concentration responses to $100 \%$, plotting the response vs. the $\log \left[\right.$ molar] agonist, and then interpolating the $\mathrm{EC}_{50}$ value.

\section{Western blot analyses}

Bone marrow aspirates were centrifuged and pellets were suspended in lysis buffer (25 mM HEPES, pH 7.0; 1 mM EDTA; 1 mM EGTA; $1 \%$ Nonidet P40; 1\% SDS) supplemented with 1:100 protease inhibitor cocktail (Sigma-Aldrich), 1:100 
phosphatase inhibitor cocktail and 50mM N-ethylmaleimide (NEM; Pierce, Rockford, IL, USA). After sonication, samples were centrifuged (4,000xg, 15 $\min , 4^{\circ} \mathrm{C}$ ) and supernatants were used for detection of protein-acrolein adducts by Western blotting. Pulverized aortas were lysed in RIPA buffer $(50 \mathrm{mM}$ Tris $\cdot \mathrm{HCl}, \mathrm{pH} 7.4,150 \mathrm{mM} \mathrm{NaCl}, 1 \mathrm{mM}$ EDTA, $0.25 \%$ sodium desoxycholate, $1 \%$ NP-40; 1:100 protease inhibitor cocktail; 1:100 phosphatase inhibitor), sonicated and centrifuged $\left(13,000 \mathrm{xg}, 15 \mathrm{~min}, 4^{\circ} \mathrm{C}\right)$. Heart was homogenized in membrane preparation lysis buffer (25mM Tris; 0.5mM EDTA; 0.5mM EGTA; protease inhibitor 1:100 dilution; phosphatase inhibitor, 1:100; $\mathrm{pH} 7.5$ ) and centrifuged $\left(14,000 \times g, 15 \mathrm{~min}, 4^{\circ} \mathrm{C}\right)$. Pellet was resuspended in lysis buffer supplemented with $1 \%$ NP-40 and incubated for $4 \mathrm{~h}^{156}$. After incubation and second centrifugation, the supernatant was collected as membrane fraction. Lungs were homogenized in ice cold lysis buffer (50mM Tris-HCL; 1 mM EDTA; 1mM EGTA; protease inhibitor, 1:100; phosphatase inhibitor, 1:100 dilution; $\mathrm{pH} 7.4$ ). Lysates were centrifuged $\left(14,000 \times g, 15 \mathrm{~min}, 4^{\circ} \mathrm{C}\right)$ and supernatants used for Western blotting ${ }^{157}$.

Total protein was measured using a commercially available kit (Bradford, BioRad, Hercules, CA, USA). For Western blot analysis of protein-acrolein adducts, protein samples $(150 \mu \mathrm{g})$ in $5 \mathrm{x}$ sample buffer $(312.5 \mathrm{mM}$ Tris base, $\mathrm{pH} 6.8$ [BioRad] or, $10 \%$ Glycerol, $11.5 \%$ SDS, $0.1 \%$ Bromphenol) supplemented with 50 mM NEM were separated under non-reducing conditions, whereas all other proteins $(30-100 \mu \mathrm{g})$ were separated under reducing conditions (buffer supplemented with $50 \mathrm{mM} \mathrm{DTT})$. Briefly, heat-denatured $\left(5 \mathrm{~min}, 95^{\circ} \mathrm{C}\right)$ protein 
samples were separated by SDS-PAGE and transferred to PVDF membranes (Bio-Rad). Membranes were processed by standard immunodetection techniques using a rabbit polyclonal antibody against $\mathrm{KLH}$ (Keyhole Limpet hemocyanin)-protein-acrolein adduct ${ }^{158}$ or using a commercially available antibody against Phospho-Akt (Ser473), Akt, Phospho-eNOS (Ser1177), eNOS (BD Biosciences, 1:1000), Phospho-p42/44 (Thr202/Tyr204), p42/44 (1:1000; Cell Signaling) or VEGFR-2 (1:250; Santa Cruz) or MMP-9 (1:5000, Chemicon, Millipore, Temecula, CA, USA). Western blots were developed using ECL ${ }^{\circledR}$ plus reagent (Amersham Biosciences, Piscataway, NJ, USA) and detected with a Typhoon 9400 variable mode imager (Amersham Biosciences). Actin antibody (1:2000, Sigma-Aldrich) detection or amido-black staining was used as loading control. Quantification of band intensities was performed using Image Quant TL software (Amersham Biosciences).

\section{Histology and immunohistochemistry}

Pelvic bones were formalin-fixed (10\% neutral buffered formalin) for $24 \mathrm{~h}$,

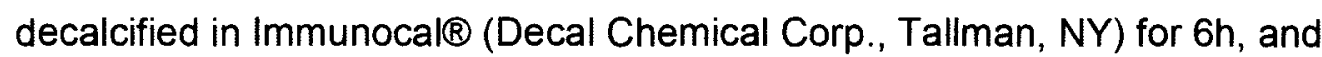
washed in running tap water $(0.5 \mathrm{~h})$. Paraffin-embedded sections $(5 \mu \mathrm{m})$ of pelvic bones were stained with hematoxylin/eosin, anti-protein-acrolein adduct (rabbit

polyclonal; $1: 1,000$ ), or normal rabbit or goat $\lg G$ (as negative controls) ${ }^{158}$. A goat anti-rabbit secondary antibody and a Vector Elite staining kit with diaminobenzadine (Dako) as chromagen were used. 


\section{MoFlow cell sorting and ID1 staining}

Whole blood (1000 $\mu$ ) was lysed (10 ml; BD PharmLyse, BD BioSciences, San Jose, CA, USA; $10 \mathrm{~min}, \mathrm{RT}$ ) and after centrifugation ( $5 \mathrm{~min}, 400 \mathrm{xg}, \mathrm{RT})$, the supernatant was aspirated and the lysing/centrifugation/aspiration steps were repeated. The cell pellet was resuspended in $1 \%$ FBS/PBS and divided into 2 equal fractions (i.e., isotype control or Flk-1/Sca-1 labeling). After centrifugation (5 min, 400xg, RT), mononuclear cells were re-suspended in 1\% FBS/PBS with murine CD16/CD32 Fc Block (0.5 $\mu \mathrm{g}$; BD Biosciences), incubated for 10 min on ice, followed by 30 min incubation on ice with anti-Sca-1 (FITC, $1 \mu \mathrm{g}$; BD BioSciences) and anti-Flk-1 (1 $\mu \mathrm{g}, \mathrm{BD}$ BioSciences) antibodies or appropriate isotype control (1 $\mu \mathrm{g} ; \mathrm{BD}$ BioSciences). Cells were then washed with $1 \%$ FBS/PBS and centrifuged ( $5 \mathrm{~min}, 400 \times g, \mathrm{RT}$ ). Based on forward and side scatter, small non-debris events were gated electronically and 200 labeled Flk-1+/Sca-1+ cells were sorted into a 1.7 uL centrifuge tube containing $2 \%$ FBS/PBS using MoFlo $\circledast$ (Beckman-Coulter). Cells were fixed with $1 \%$ paraformaldehyde for 5 $\min$. on ice. Triton-100X was then added to increase the permeability for $5 \mathrm{~min}$. on ice. Cells were then washed using $0.1 \%$ Triton-100X wash buffer, spun down at $3 \mathrm{rpm}$ for $5 \mathrm{~min}$. then aspirated. Cells were then stained with murine anti-ID1 (1:50; Santa Cruze) for $30 \mathrm{~min}$. in $0.1 \%$ Triton on ice, then washed with $0.1 \%$ Triton wash buffer and aspirated. Cells were stained using secondary anti-rabbit PE fluorophore $(1: 25 ;)$. Cells were once again washed with $2 \%$ PBS/FBS spun down and aspirated. Then 100uL of $2 \%$ FBS/PBS was added and then cell spun onto a cytospin slide at $300 \mathrm{Xg}$. Slides mounted in DAPI-containing Slow Fade ${ }^{\circledR}$ 
Gold anti-fade reagent (Invitrogen), and viewed using a Zeiss confocal microscope.

\section{Results}

\section{FlK $^{+} / \mathrm{Sca}^{+}$Cell characterization}

To better understand the selective nature of acrolein inhibition, a more extensive screen of antigenic markers on Flk- $1^{+} / \mathrm{Sca}-1^{+}$cells (stem/progenitor and B-/T-cell markers) from saline and VEGF/AMD3100-treated mice was conducted by flow cytometry. VEGF/AMD3100 significantly increased $\mathrm{Flk}-1^{+} / \mathrm{Sca}-1^{+}$cells expressing a variety of stem and $\mathrm{B}-\mathrm{T}$-cell antigenic markers especially cells coexpressing CD31/CD45R(B220)/CD133 and CD31/CD45R(B220)/CD19 (Fig.

\section{A-F).}

\section{Effects of acrolein on circulating Flk $-1^{+} /$Sca $-1^{+}$cells}

Analysis of the mononuclear cell population of peripheral blood showed that Flk-

$1^{+} /$Sca- $1^{+}$cells were a relatively small $(3-5 \mu \mathrm{m})$, sub-lymphocytic, non-debris cell population with further characterization showing stem and endothelial cell markers (Figs. 3A-2E). 
Figure 2

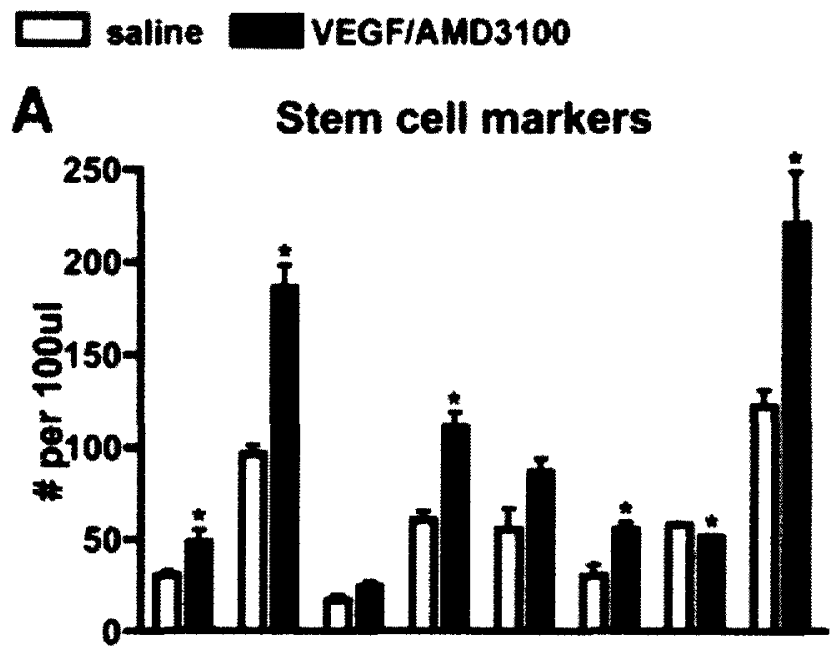

B

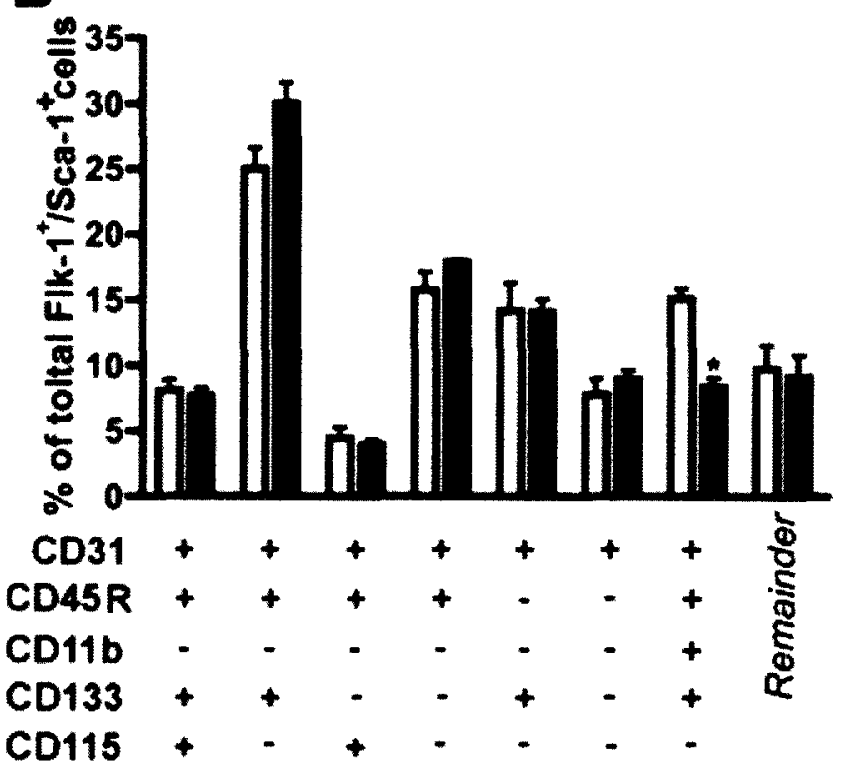




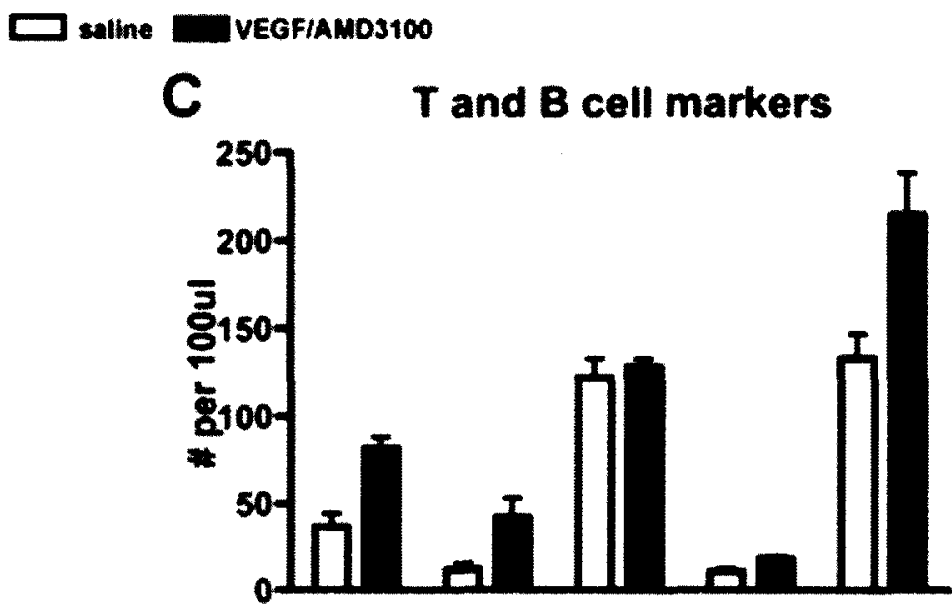

D

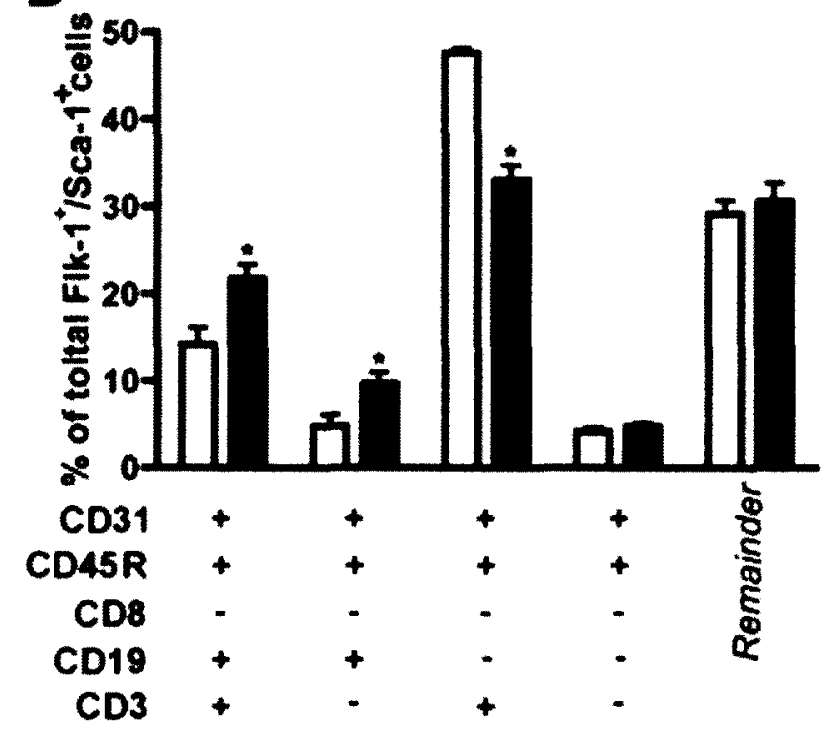




\section{E}

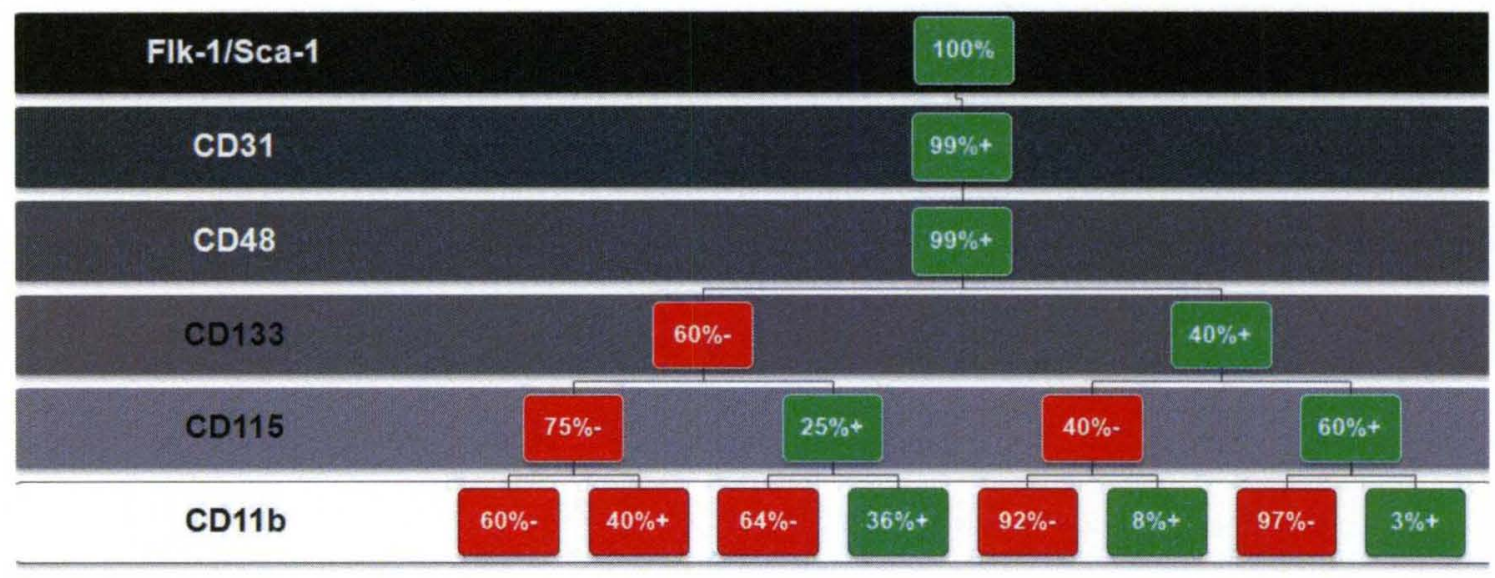

F

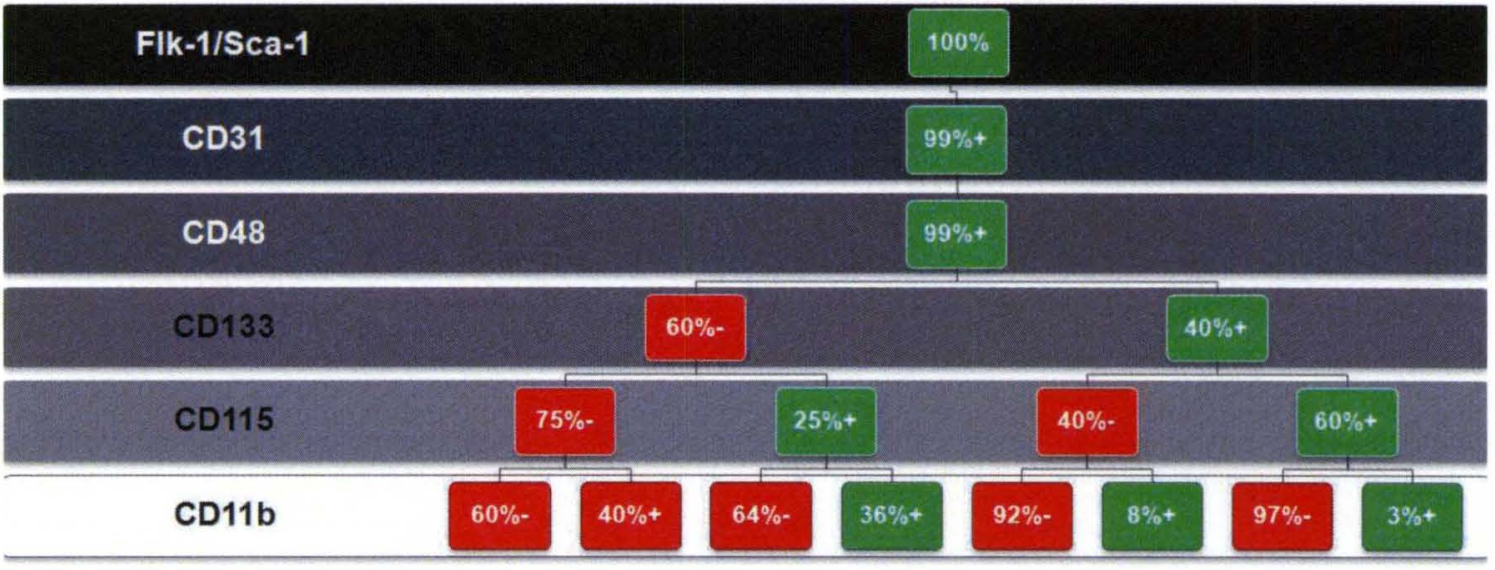


Figure 2: Hierarchical relationships of $\mathrm{Flk}^{+} / \mathrm{Sca}{ }^{+}$Cells. : A-B, Progenitor cell antigens, and, C-D, lymphocytic differentiation marker antigens expressed on Flk-1/Sca-1 cells. ,E, Progenitor cell antigens, and, F, lymphocytic differentiation marker antigens expressed on Flk-1/Sca-1 cells. 
Figure 3
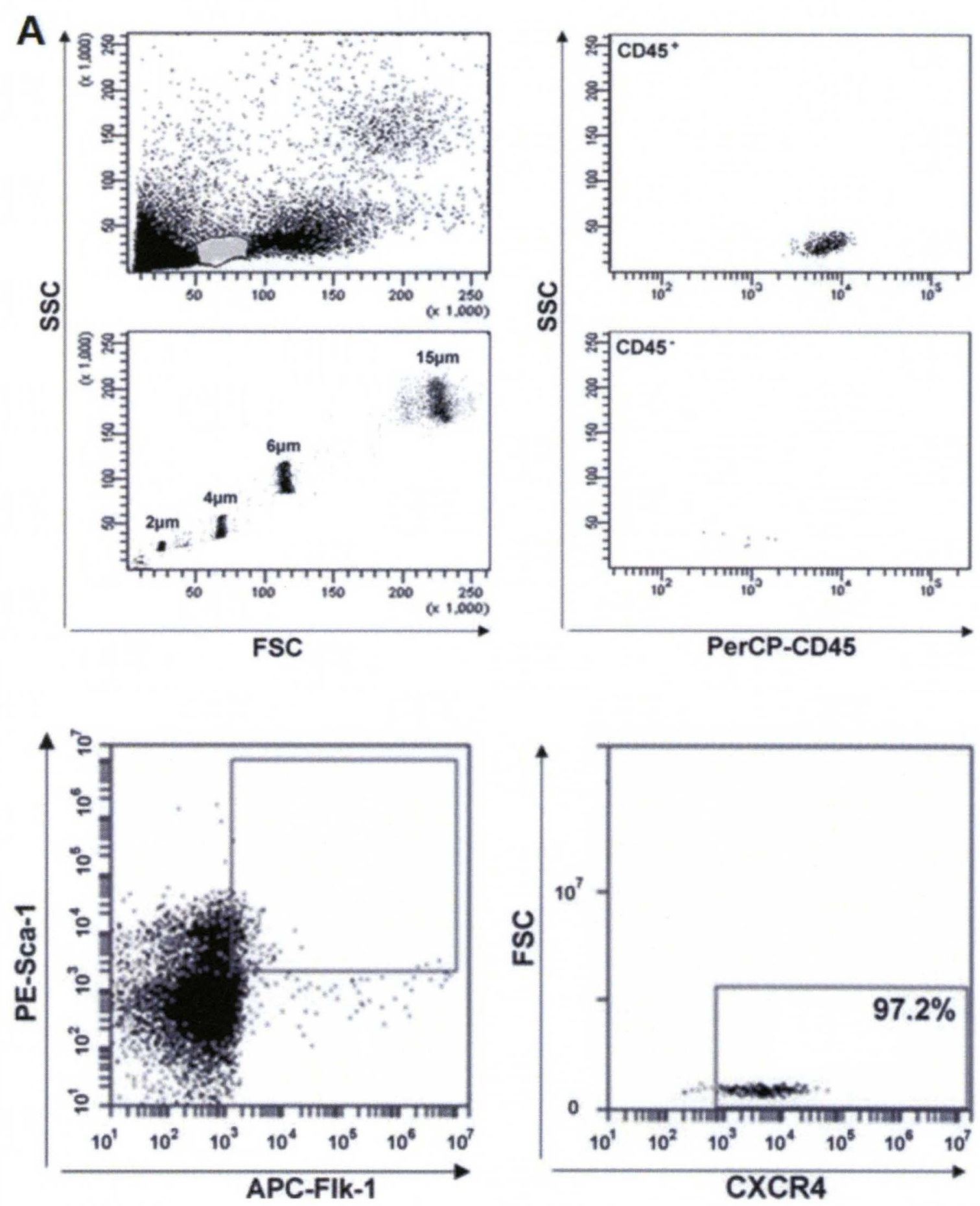
B.

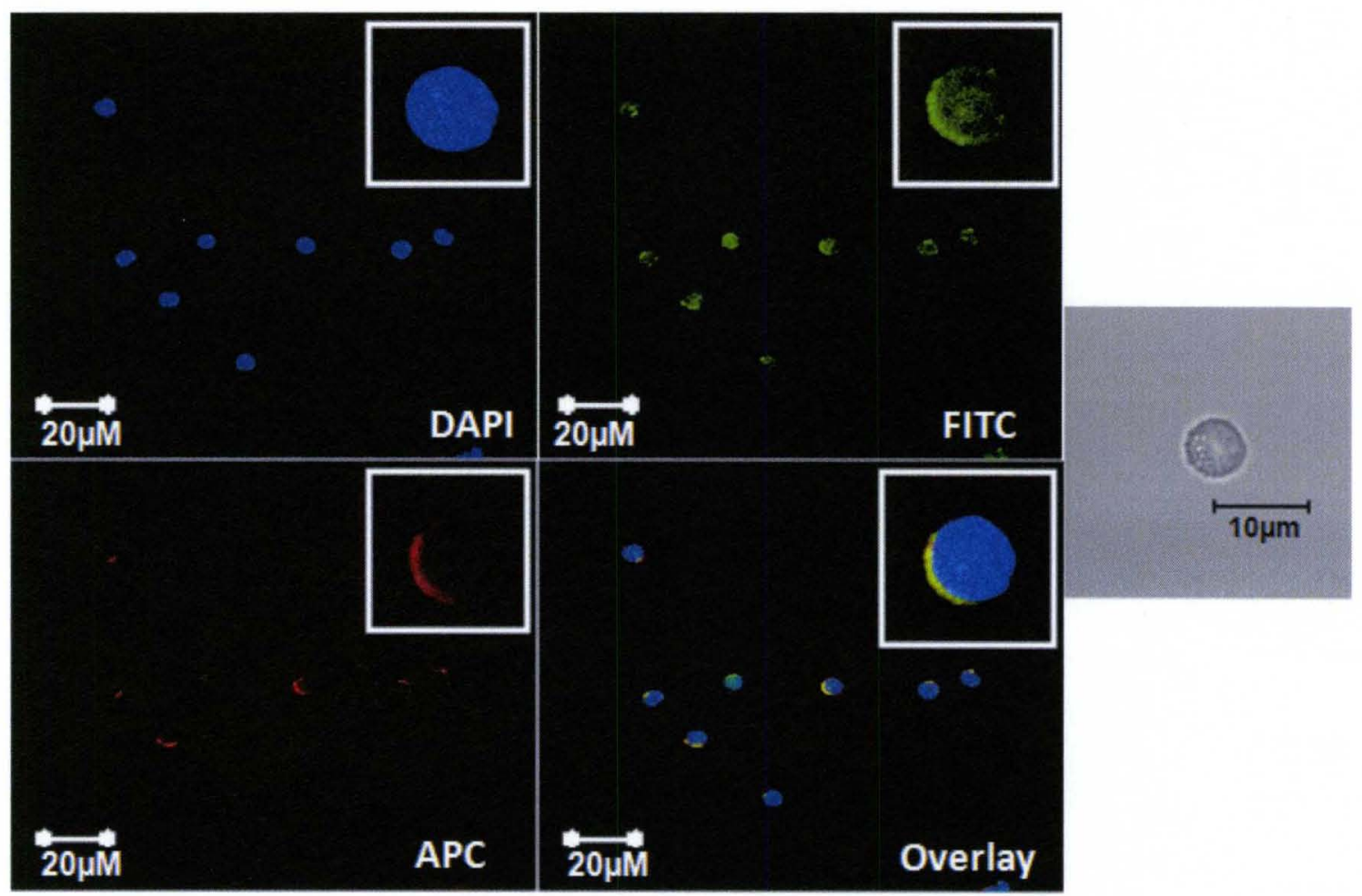


c.

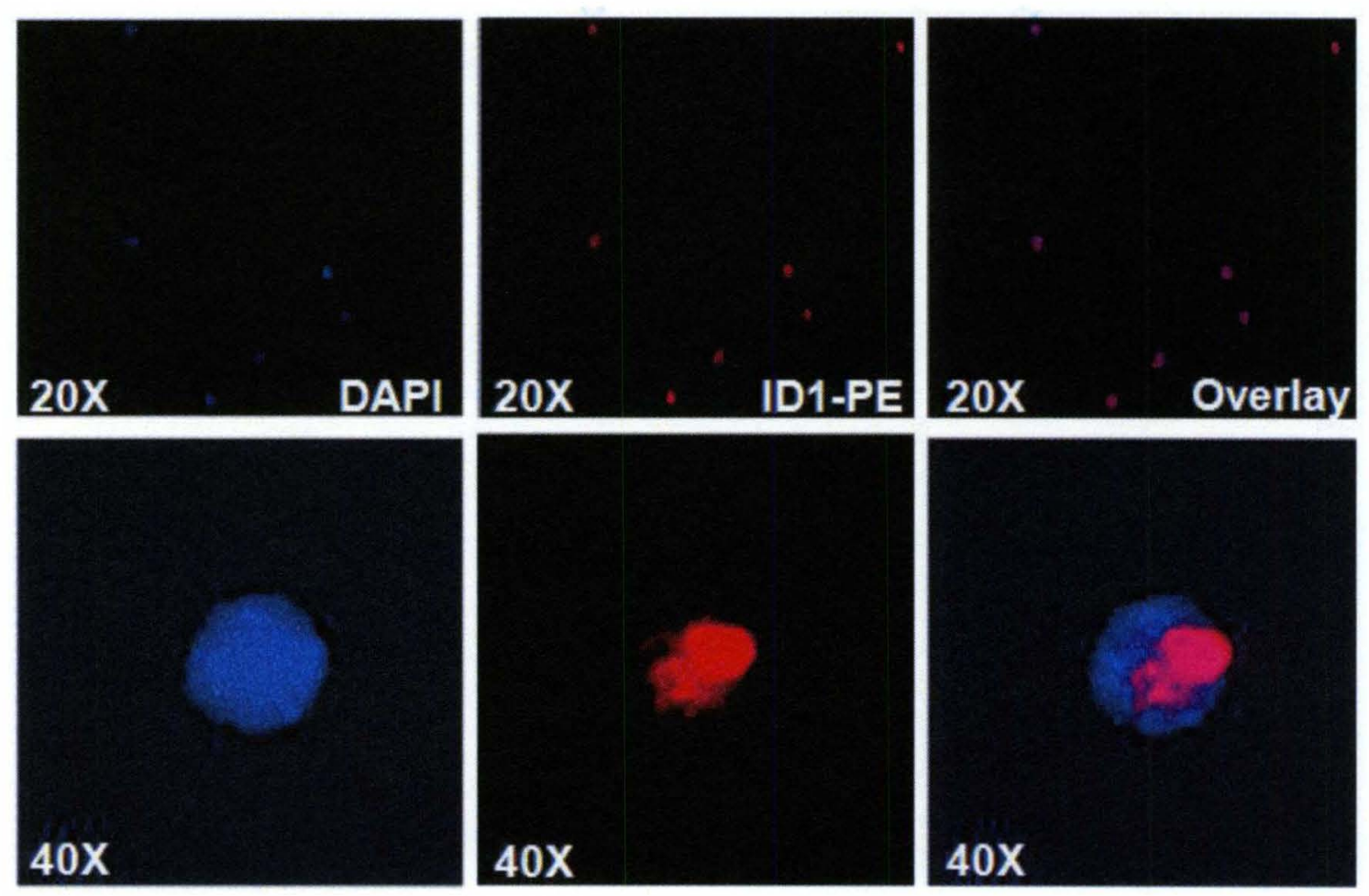




\section{Figure 3: Characterization of Flk-1 ${ }^{+} / \mathrm{Sca}-1^{+}$progenitor cells by flow}

cytometry and microscopy. Representative dot plots of A, forward(FSC) and side-scatter (SSC) of circulating cells and size beads indicating an approximate size range of Flk- $1^{+} / \mathrm{Sca}-1^{+}$cells $(3-5 \mu \mathrm{m})$ Dot plots of SSC and PerCP-CD45 fluorescence of Flk $-1^{+} / \mathrm{Sca}-1^{+}$cells representing CD45 positive (CD45, $98.5 \pm 0.3 \%)$ and CD45 negative cells (CD45", 1.2 $\pm 0.3 \%$ ). Dot plots of FSC and PE-CXCR4 fluorescence of Flk-1 $1^{+} / \mathrm{Sca}-$ $1^{+}$cells that are CXCR4 positive (97.2\%). B, Brightfield and confocal images of Flk-1/Sca-1-double positive cells sorted by MoFlo for immunofluorescence detection of antigen co-localization. C, Confocal image of sorted Flk-1 $1^{+} / \mathrm{Sca}-1^{+}$cells stained with Id 1 antibody. Nuclei were stained with DAPI. 
Acrolein exposure induced a selective and dose-dependent decrease of circulating Flk-1 $1^{+} / \mathrm{Sca}-1^{+}$cells (Fig. 4C). The number of Flk $-1^{+} / \mathrm{Sca}-1^{+}$cells was significantly reduced by $77 \pm 10 \%$ following exposure to $1 \mathrm{ppm}$ acrolein for 4 consecutive days (6h/d; air: $413 \pm 109$ cells per 50,000 events; acrolein: $97 \pm 19$ cells per 50,000 events; $n=8,8 ; p<0.05$ ). However, acrolein exposures $(1 \mathrm{ppm}$; $6 \mathrm{~h} / \mathrm{d}$ ) for 1,2 , or 4 days did not affect the number of circulating Sca- $1^{+}$cells (Fig. 4D). Exposure of mice to a higher dose of acrolein ( $5 \mathrm{ppm} ; 6 \mathrm{~h})$, though, decreased Flk $-1^{+} / \mathrm{Sca}-1^{+}$cells significantly by $43 \pm 10 \%$ compared to air-exposed mice (air: $4.3 \pm 0.7$ cells $/ \mu \mathrm{L}$; acrolein: $2.4 \pm 0.4$ cells $/ \mu \mathrm{L}, \mathrm{n}=8,8 ; p<0.05$; Fig. $4 \mathrm{E}$ ). A brief acrolein exposure (5ppm; $2 \mathrm{~h})$, however, did not alter circulating Flk$1^{+} /$Sca- $1^{+}$cells (air: $6.3 \pm 2.4$ cells $/ \mu \mathrm{L} ;$ acrolein: $7.7 \pm 1.4$ cells $/ \mu \mathrm{L}, \mathrm{n}=4,4 ; p<0.05$ ) or Sca- $1^{+}$cell level. Acrolein exposure of $0.5 \mathrm{ppm}(6 \mathrm{~h} / \mathrm{d} \times 4 \mathrm{~d})$ had no effect on the number of circulating $\mathrm{Flk}-1^{+} / \mathrm{Sca}-1^{+}$or Sca- $1^{+}$cells as compared with air controls indicating a narrow threshold range of acrolein action. Furthermore, mice allowed 7 days of recovery after a 4-day acrolein ( $1 \mathrm{ppm}, 6 \mathrm{~h} / \mathrm{d})$ exposure had similar numbers of circulating $\mathrm{Flk}-1^{+} / \mathrm{Sca}-1^{+}$cells compared with air-exposed controls (Fig. 4E). Although $1 \mathrm{ppm}$ acrolein (6h/d $\times 4 \mathrm{~d}$ ) did not alter plasma lipids (Table 7) or leukocyte blood cell counts, a $6 \mathrm{~h}$ exposure to a higher acrolein level (5 ppm) significantly decreased leukocyte blood cell counts (Table 8). Acrolein exposure increased Annexin V/7AAD staining in circulating Flk-1/Sca-1 double positive cells (Fig. 4G). 
Figure 4

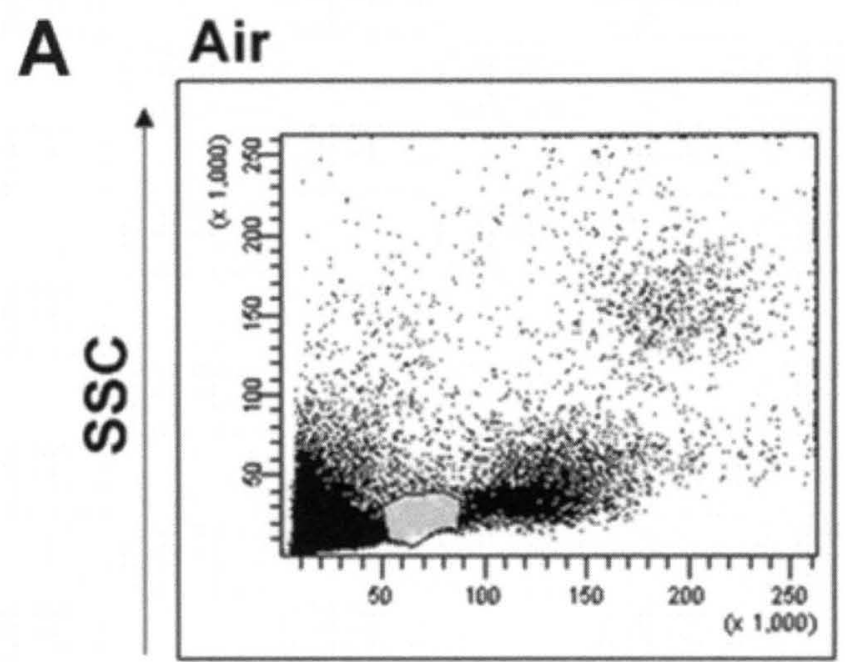

\section{Acrolein}

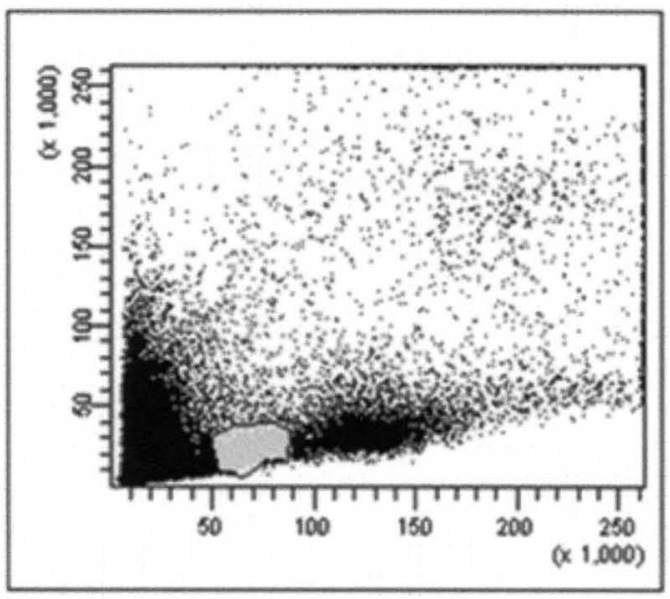

FSC

B.
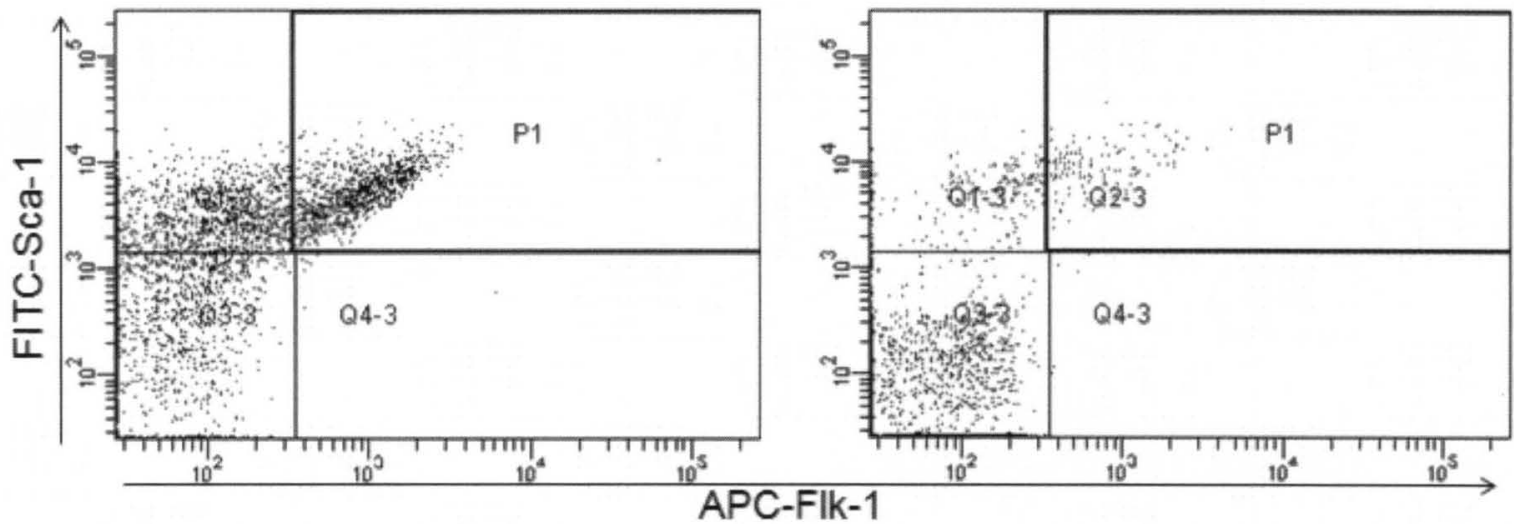
C

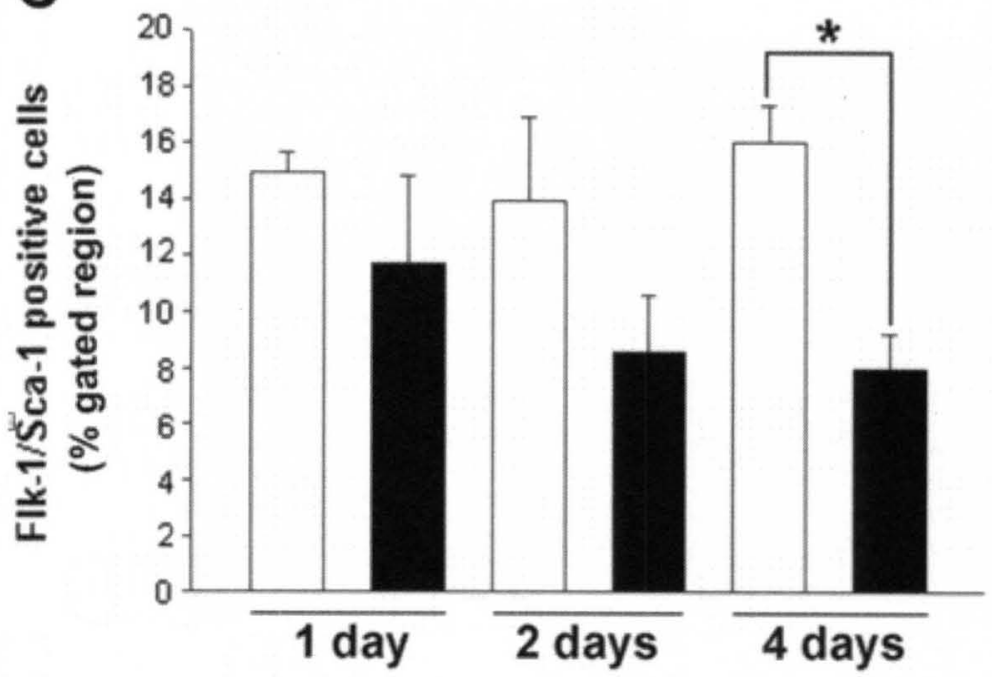

D

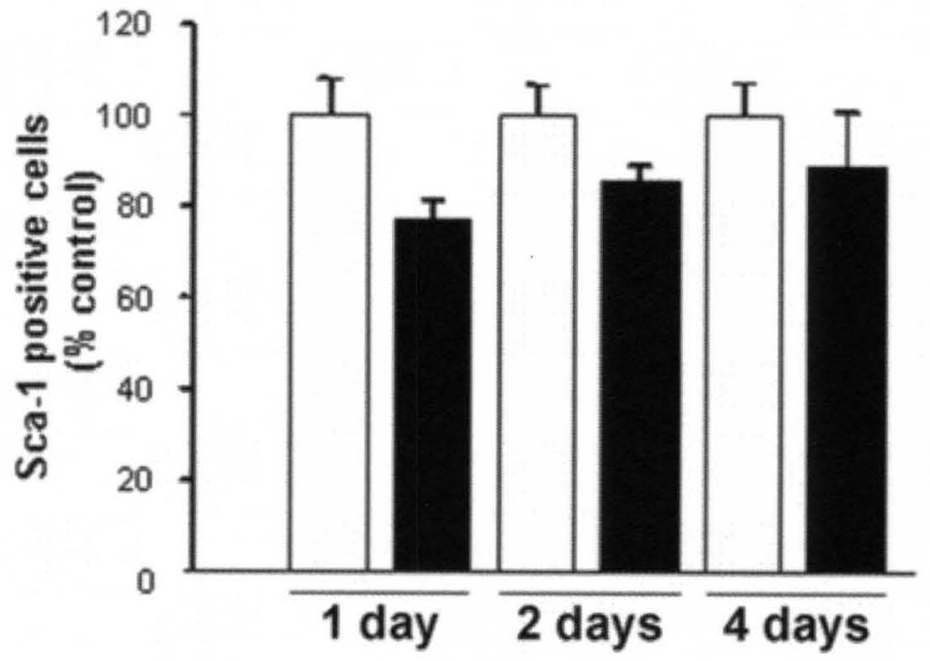


E

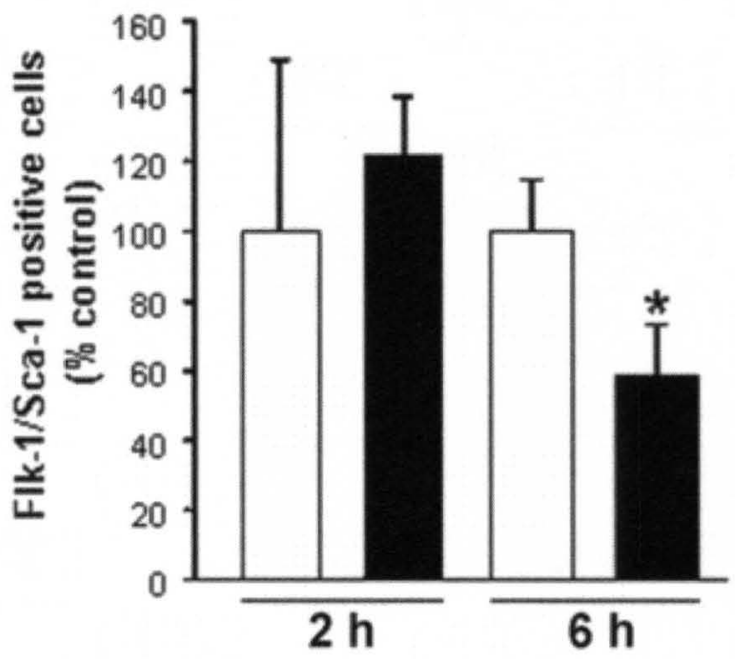

F

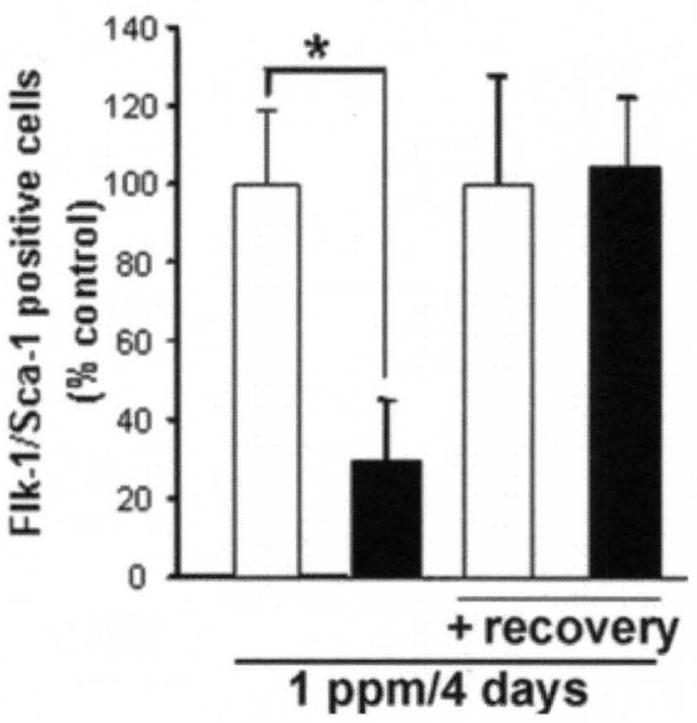


G.
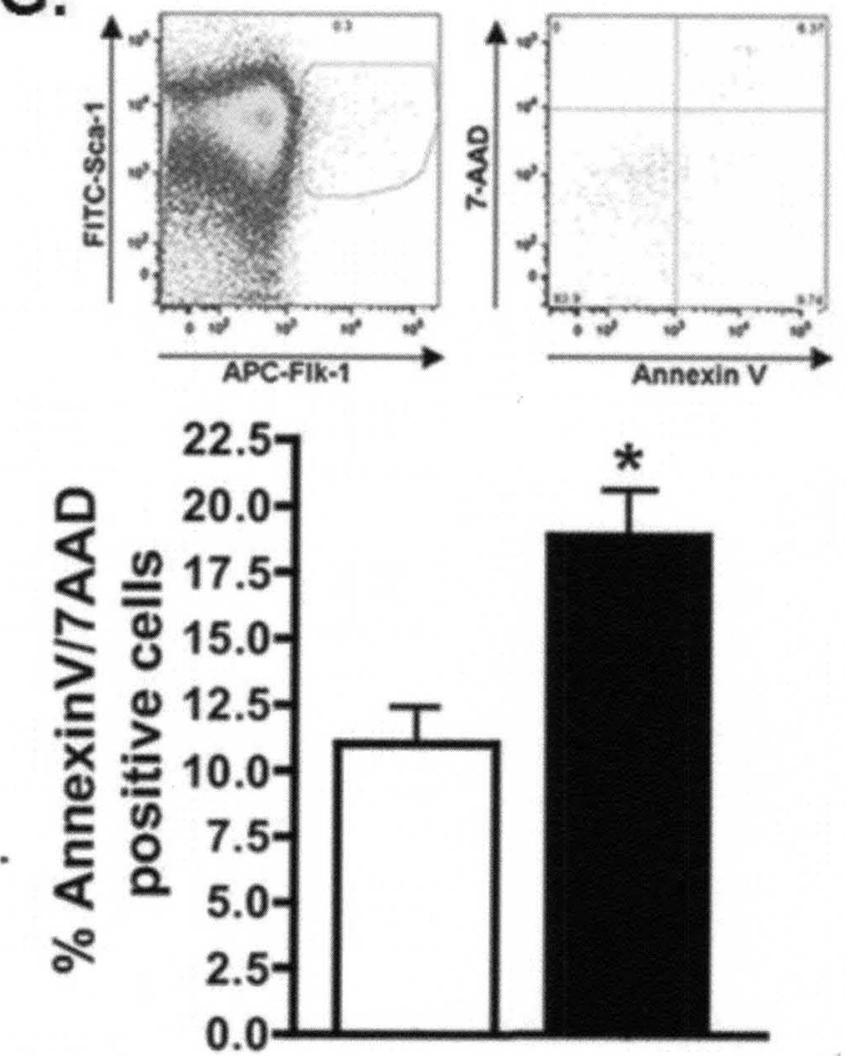
Figure 3: Effects of acrolein on circulating progenitor cells. A, Flow cytometry analysis of forward- (FSC) and side-scatter (SSC) of peripheral blood mononuclear cells of mice breathing filtered air or acrolein (1ppm, 6h/day, 4 days). B, Representative two color (APC-Flk-1 and FITC-Sca-1) flow cytometry dot plots of circulating Flk $-1^{+} / \mathrm{Sca}-1^{+}$cells in peripheral blood of mice after 4 days of exposure to filtered air or acrolein. Levels of C, Flk $-1^{+} / \mathrm{Sca}-1^{+}$cells and $\mathrm{D}, \mathrm{Sca}-1^{+}$cells in peripheral blood after breathing filtered air or acrolein for indicated days $(n=8-12)$. E, Flk-1 ${ }^{+} /$Sca$1^{+}$cells in blood obtained from mice breathing filtered air or $5 \mathrm{ppm}$ acrolein for 2 or $6 \mathrm{~h} . \mathbf{F}, \mathrm{Flk}-1^{+} / \mathrm{Sca}-1^{+}$cells in blood of mice breathing air or $1 \mathrm{ppm}$ acrolein (6h/d, 4d) and after 7 days recovery G, Representative dot plots of APC-FIk-1 and FITC-Sca-1 double positive cells stained for 7-AAD (necrosis marker) and Annexin V (apoptosis marker), and quantification of percentage Annexin $V$ and 7-AAD stained cells from air and acroleinexposed mice. $\left(n=4 ;{ }^{*} p<0.05\right)$. 
Table 7

Blood and plasma variables in mice exposed to air or acrolein.

\begin{tabular}{|c|c|c|c|c|}
\hline & Air & Acrole in 1ppm & Air & Acrolein, $5 \mathrm{ppm}$ \\
\hline Cholesterol $^{\mathrm{a}}$ & $73.2 \pm 3.1$ & $70.1 \pm 2.7$ & $60.9 \pm 4.1$ & $52.2 \pm 0.3$ \\
\hline $\mathrm{HDL}^{2}$ & $54.6 \pm 3.2$ & $45.6 \pm 3.6$ & $45.8 \pm 3.2$ & $50.2 \pm 0.3$ \\
\hline LDL $^{a}$ & $10.3 \pm 0.2$ & $10.9 \pm 0.7$ & $8.1 \pm 0.6$ & $9.4 \pm 0.2$ \\
\hline Triglycerides" & $17.9 \pm 3.1$ & $14.5 \pm 1.9$ & $24.8 \pm 4.7$ & $17.7 \pm 0.3$ \\
\hline TPb & $4.1 \pm 0.1$ & $3.8 \pm 0.1$ & $3.7 \pm 0.1$ & $3.7 \pm 0.8$ \\
\hline$A^{A L B}{ }^{b}$ & $2.7 \pm 0.1$ & $2.7 \pm 0.1$ & $2.5 \pm 0.1$ & $2.5 \pm 0.9$ \\
\hline $\mathrm{LDH}^{\mathrm{C}}$ & $167.6 \pm 17.2$ & $127.2 \pm 9.9$ & $264.5 \pm 26.1$ & $167.5 \pm 12.1^{\circ}$ \\
\hline $\mathrm{CK}^{\mathrm{c}}$ & $261.6 \pm 21.2$ & $245.1 \pm 30.1$ & $198 \pm 8.2$ & $247 \pm 5.3$ \\
\hline$A L T^{c}$ & $56.5 \pm 7.8$ & $48.2 \pm 6.4$ & $25.7 \pm 3.6$ & $25.8 \pm 0.9$ \\
\hline ASTC & $42.2 \pm 7.3$ & $25.9 \pm 3.9$ & $62.8 \pm 8.7$ & $69.3 \pm 10.7$ \\
\hline
\end{tabular}

Male, 12-14 week old mice were exposed to air or $1 \mathrm{ppm}$ acrolein $(6 \mathrm{~h} / \mathrm{d}, 4 \mathrm{~d}, \mathrm{n}=11$ mice/group) or $5 \mathrm{ppm}$ acrolein ( $6 \mathrm{~h} / \mathrm{d}, 1 \mathrm{~d}, n=4$ mice/group). Values are mean $\pm S E M$. Abbr. HDL, high density lipoprotein cholesterol; LDL, low density lipoprotein cholesterol; TP, total protein; ALB, albumin; LDH, lactate dehydrogenase; CK, creatine kinase; ALT, alanine aminotransferase: $A S T$, aspartate aminotransferese. Units: ${ }^{a}=[\mathrm{mg} / \mathrm{dL}]{ }^{b}=$ $[\mathrm{g} / \mathrm{dL}],{ }^{\mathrm{c}}=[\mathrm{U} / \mathrm{L}] \mathrm{;}^{*}, p<0.05 \mathrm{vs}$. Air-matched group. 
Table 8

Complete blood count in mice exposed to air or acrolein.

\begin{tabular}{|c|c|c|c|c|}
\hline & Air & Acrolein. 1ppm & Air & Acrolein, $5 \mathrm{ppm}$ \\
\hline WBC & $2370 \pm 585$ & $1775 \pm 293$ & $2690 \pm 381$ & $935 \pm 33^{*}$ \\
\hline $\mathrm{NE}^{2}$ & $362 \pm 64$ & $355 \pm 51$ & $472 \pm 61$ & $138 \pm 16^{*}$ \\
\hline$L Y^{2}$ & $1942 \pm 518$ & $1448 \pm 262$ & $2135 \pm 325$ & $752 \pm 21^{*}$ \\
\hline MO" & $57 \pm 15$ & $60 \pm 10$ & $78 \pm 15$ & $35 \pm 5^{*}$ \\
\hline$R B C^{\circ}$ & $9.03 \pm 0.30$ & $8.92 \pm 0.24$ & $8.18 \pm 0.27$ & $8.24 \pm 0.26$ \\
\hline $\mathrm{HCl}(\%)$ & $42.2 \pm 1.2$ & $41.4 \pm 1.3$ & $37.4 \pm 1.1$ & $36.9 \pm 1.2$ \\
\hline$H b^{c}$ & $11.1 \pm 0.3$ & $11.1 \pm 0.3$ & $11.3 \pm 0.1$ & $12.2 \pm 0.2$ \\
\hline$M C V^{d}$ & $46.9 \pm 0.3$ & $46.3 \pm 0.6$ & $45.7 \pm 0.3$ & $44.8 \pm 0.4$ \\
\hline $\mathrm{MCH}^{*}$ & $12.2 \pm 0.1$ & $12.4 \pm 0.2$ & $14.3 \pm 0.1$ & $14.4 \pm 0.2$ \\
\hline MCHC & $26.1 \pm 0.1$ & $26.8 \pm 0.5$ & $31.2 \pm 0.3$ & $32.1 \pm 0.3$ \\
\hline RDW $(\%)$ & $17.3 \pm 0.5$ & $17.5 \pm 1.7$ & $17.3 \pm 0.3$ & $16.7 \pm 0.1$ \\
\hline PLT" & $835 \pm 50$ & $789 \pm 46$ & $845 \pm 47$ & $758 \pm 28$ \\
\hline MPV & $3.8 \pm 0.1$ & $3.8 \pm 0.1$ & $4.1 \pm 0.1$ & $3.9 \pm 0.2$ \\
\hline
\end{tabular}

Male, 12-14 week old mice were exposed to air or $1 \mathrm{ppm}$ acrolein $(6 \mathrm{~h} / \mathrm{d}, 4 \mathrm{~d}, n=8$ mice/group) or $5 \mathrm{ppm}$ acrolein (6h/d, $1 \mathrm{~d}, \mathrm{n}=4 \mathrm{mice} / \mathrm{group}$ ). Values are mean \pm SEM. Abbr: WBC, white blood cells; NE. neutrophils: LY, lymphocytes: MO, monocytes: RBC, red blood cells; $\mathrm{HCt}$, hematocrit; $\mathrm{Hb}$, hemoglobin; MCV, mean corpuscular volume; $\mathrm{MCH}$, mean corpuscular hemoglobin; MCHC, mean corpuscular hemoglobin concentration; RDW, red cell distribution width; PLT. platelets; MPV. mean platelet volume. Units: ${ }^{a}=\left[\times 10^{3} / \mu \mathrm{L}\right],{ }^{b}=\left[\times 10^{6} / \mu \mathrm{L}\right],^{c}=[\mathrm{g} / \mathrm{dL}]^{d}=[\mathrm{fL}]{ }^{*}=[\mathrm{pg}]^{*}, p<0.05$ vs. airmatched group. 


\section{Acrolein exposure increased number of bone marrow-derived cells (BMDC)}

To further evaluate the condition of the EPC within the bone marrow culture was performed. Acrolein exposure increased the number of Dil-acLDL/FITC-UElectin-double positive cells in culture on day 7 (Fig. 5). After 7 days of culture, outgrowths from bone marrow-derived Dil-acLDL/FITC-UE-lectin-double positive cells (Fig. 5B), had more cells from acrolein-exposed mice than air-exposed as indicated by DAPI staining (nuclear; blue fluorescence; Fig. 5B). Furthermore, the cells positive for Dil-acLDL (red fluorescence) and FITC-UE-lectin (green fluorescence) were increased by acrolein exposure compared with air-exposed controls (Fig. 5B). Image overlay showed co-localization of EPCs markers (DilacLDL, FITC-UE-lectin) indicating that acrolein enhanced the proliferative capacity of endothelial progenitor-like cells (orange) in culture. Compared with cells from air-exposed (control) mice, there was a 3- to 3.6-fold increase in the Dil-acLDL/ ITC-UE-lectin double positive cells isolated from mice exposed to acrolein (5 ppm, 6h; Fig. 5C; 1 ppm, 4d; Fig. 5D) after 7 days in culture. The identification of these proliferating cells as endothelial progenitor-like cells was also supported by immunocytochemical staining of cultured BMDC for APC-Flk-1 and FITC-Sca-1 (i.e., markers used in flow cytometry) on culture day 7 . Thus, in comparison with air, acrolein exposure (1 ppm, 4d) increased Flk-1 ${ }^{+} / \mathrm{Sca}-1^{+}$cells by 1.7 -fold. Taken together, these data showed that acrolein exposure enhanced bone marrow-derived endothelial progenitor-like cell proliferation in culture. 
Figure 5

A
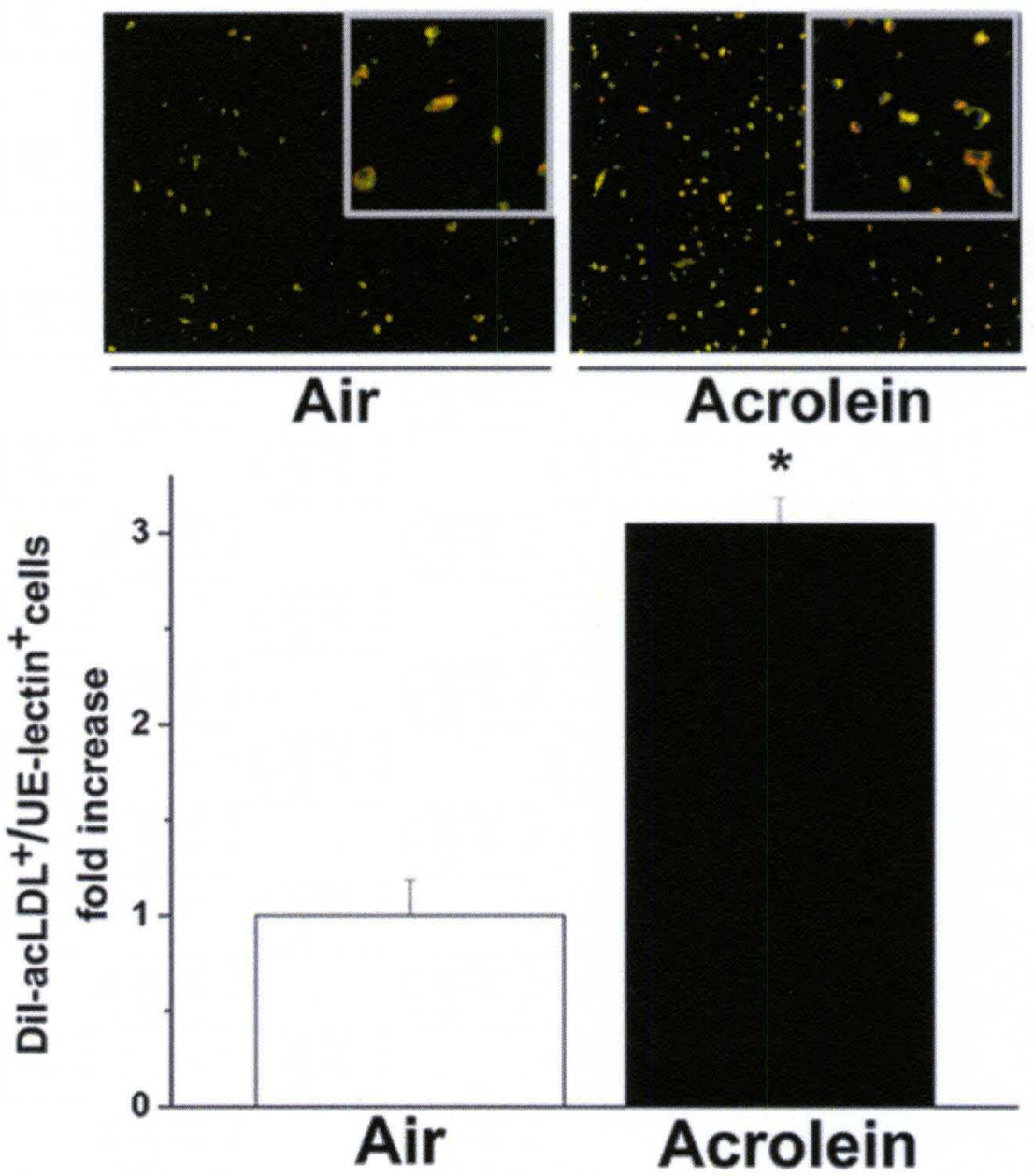
B
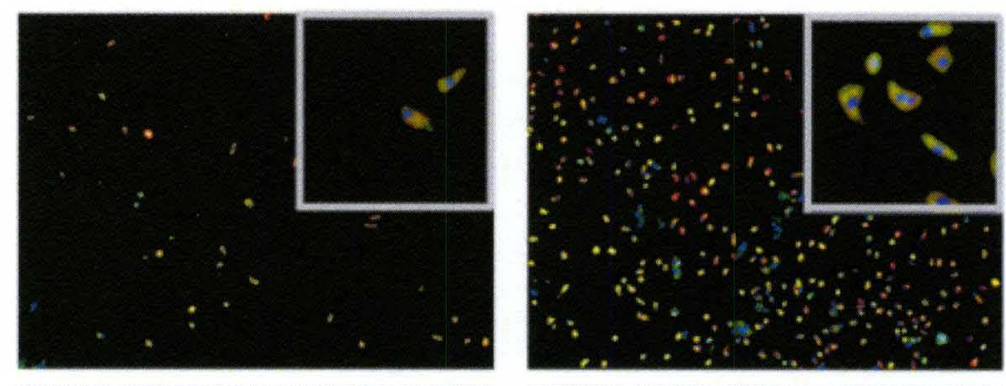

Air

Acrolein

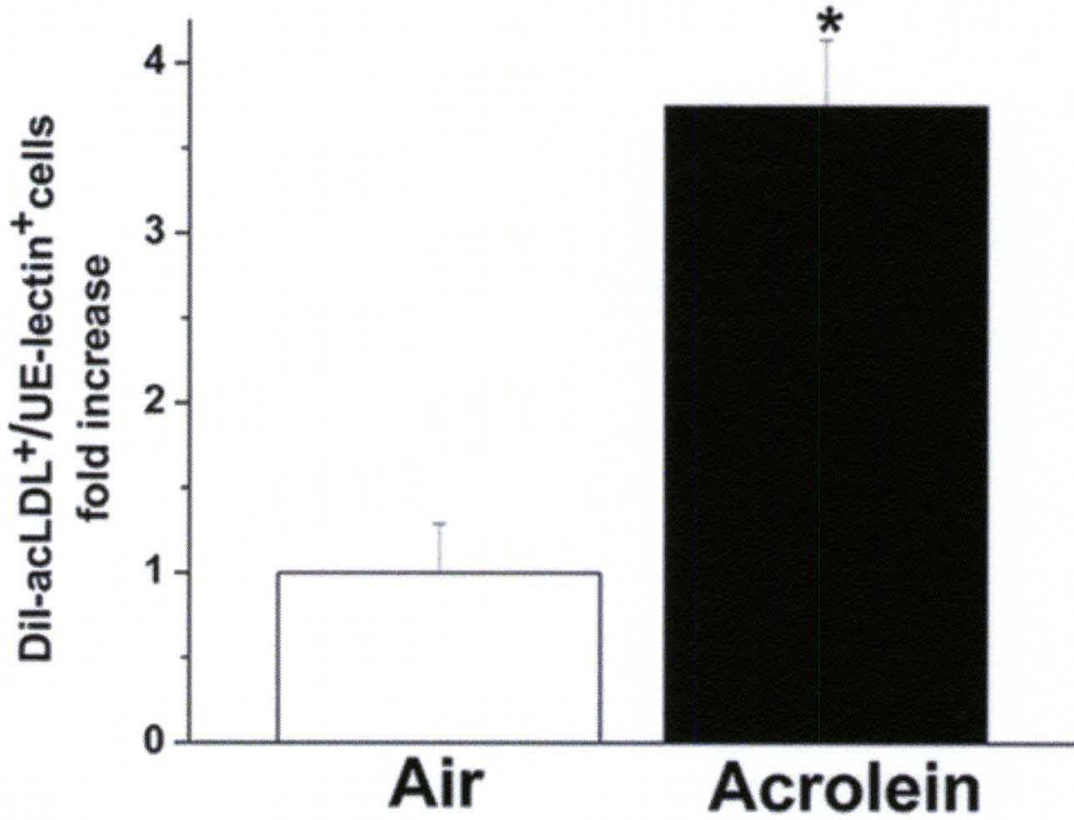


C
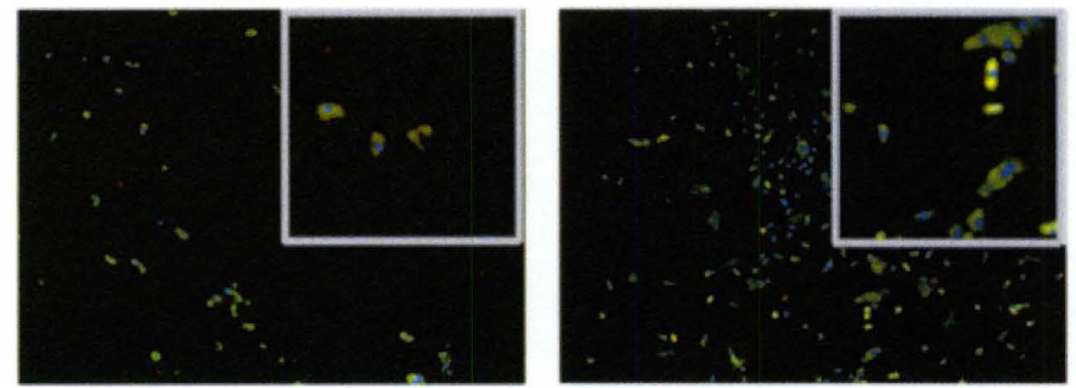

Air

Acrolein

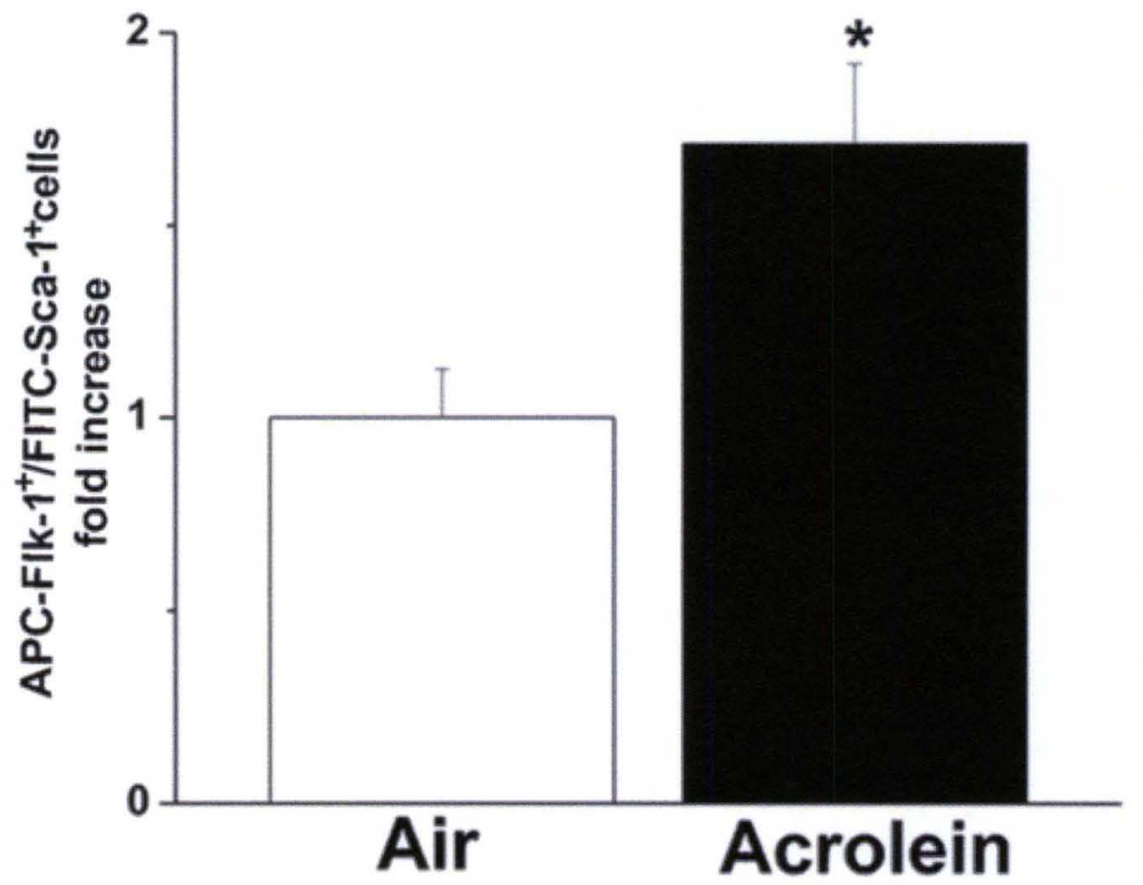


Figure 5: Acrolein increases proliferation of bone marrow-derived cells. Representative fluorescence images (upper panels) and the number of (lower panels) of Dil-acLDL ${ }^{+} /$FITC-UE-lectin ${ }^{+}$cells isolated from bone marrow of mice exposed to air or B, $5 \mathrm{ppm}$ acrolein for $6 \mathrm{~h} \mathrm{C,} \mathrm{or} 1 \mathrm{ppm}$ acrolein (6h/d, 4 days). Mononuclear cells were isolated from the bone marrow and grown in culture for 7 days. Cells were labeled with Dil-acLDL and FITC-UE-lectin and nuclei were stained with DAPI. Merged images show co-localization of both markers in orange (i.e., double-positive cells). D, Representative fluorescence images (upper panel) and analysis (lower panel) of Flk- $1^{+} / \mathrm{Sca}-1^{+}$-cells from mice exposed to air or $1 \mathrm{ppm}$ acrolein (6h/d, 4d) after day 7 of culture. Cells were labeled with FITC-Flk-1 and APC-Sca-1 and with DAPI for nuclear staining. Merged images show colocalization of the markers. Changes in the number of Dil-acLDL $/$ FITCUE-lectin ${ }^{+}$and $\mathrm{Flk}-1^{+} / \mathrm{Sca}-1^{+}$cells are presented as fold increase in double positive cells compared with controls $\left(n=4 ;{ }^{*} p<0.05\right.$, air vs. acrolein exposure). 


\section{Protein acrolein adducts}

To determine whether acrolein could directly reach the bone marrow cells, we examined the abundance of protein-acrolein adducts in plasma and bone marrow by Western blotting and immunohistochemistry (Fig. 6). Protein-acrolein adducts were detected by Western blotting of plasma (Fig. 6A) and bone marrow lysates (Fig. 7B) of air- and acrolein-exposed (1 ppm, 4d) mice. Abundant acrolein adducts were observed in proteins with molecular weights of $\approx 250$ and $\approx 150 \mathrm{kDa}$ in plasma and of $\approx 250, \approx 37, \approx 18$ and $\approx 17 \mathrm{kDa}$ in the bone marrow. Acrolein inhalation led to a significant increase in the intensity of several bands, including a 2.5 -fold increase in a plasma protein band of $\approx 150 \mathrm{kDa}$ and a 2-fold increase for a bone marrow protein band of $\approx 250 \mathrm{kDa}$, compared with controls (Fig. 6). Similarly, immunohistochemical staining of femur (proximal head) cross-sections with protein-acrolein adduct antibody was substantially stronger in acroleintreated (1 ppm, 4d) bone compared with controls (Fig. 6C). Adduct distribution was quite heterogeneous in both acrolein- and air-exposed mice, however, distinct, intense positive staining of protein-acrolein adducts was observed in blood vessels within the connective tissue as well as in the ostea of the bone trabeculae (Fig. 6C, see black arrows). More diffuse staining was present in the bone marrow matrix, i.e., hematopoietic tissue (Fig. 6C, yellow arrows), where some focal, intense staining was localized to the largest bone marrow cells within the endosteum at the border between the bone marrow cavity and compact bone (Fig. 6C, yellow arrow). 
Figure 6
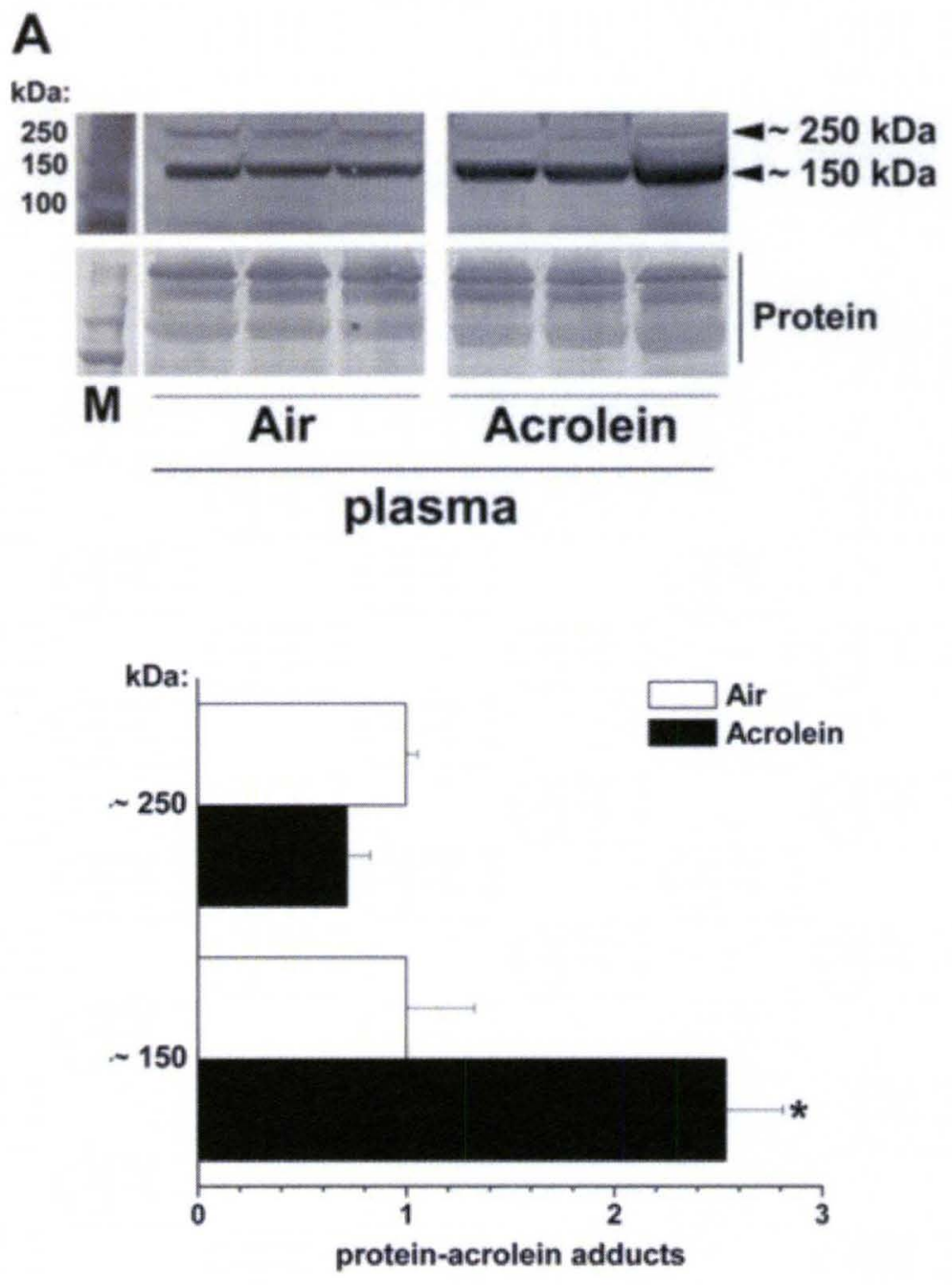

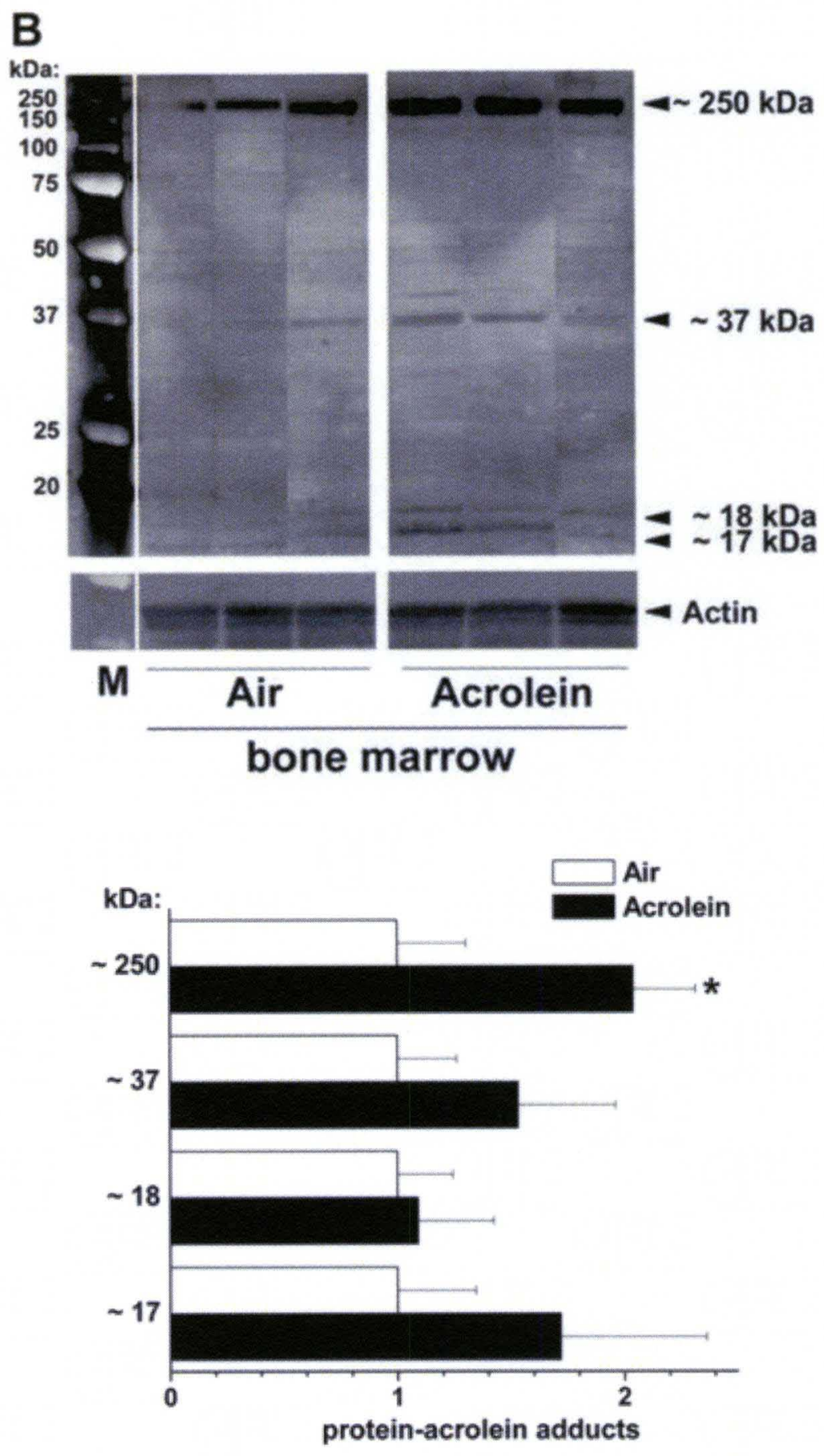


\section{Air}
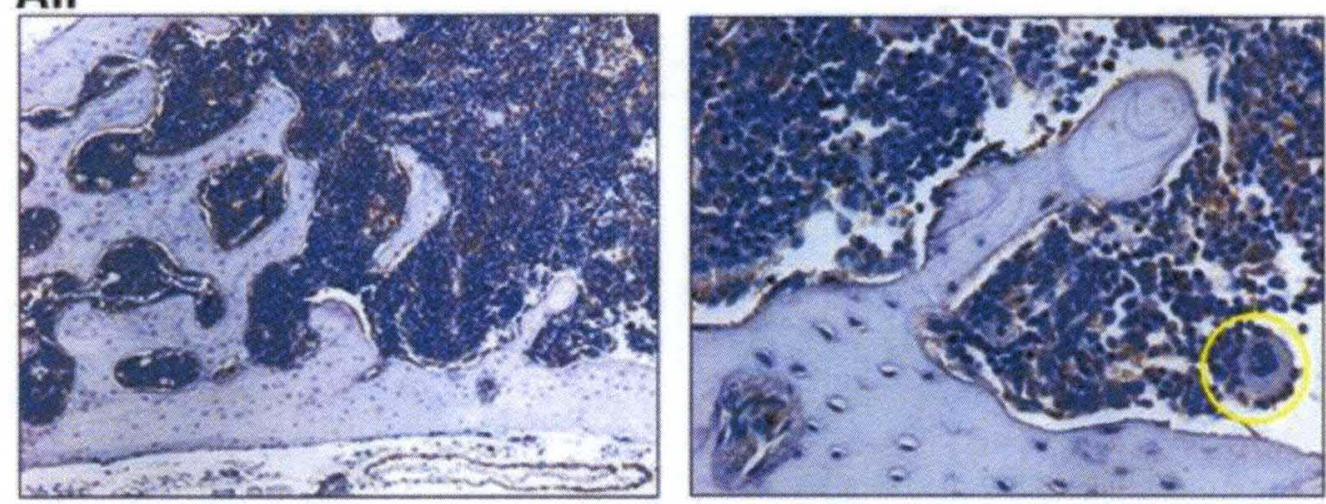

\section{Acrolein}
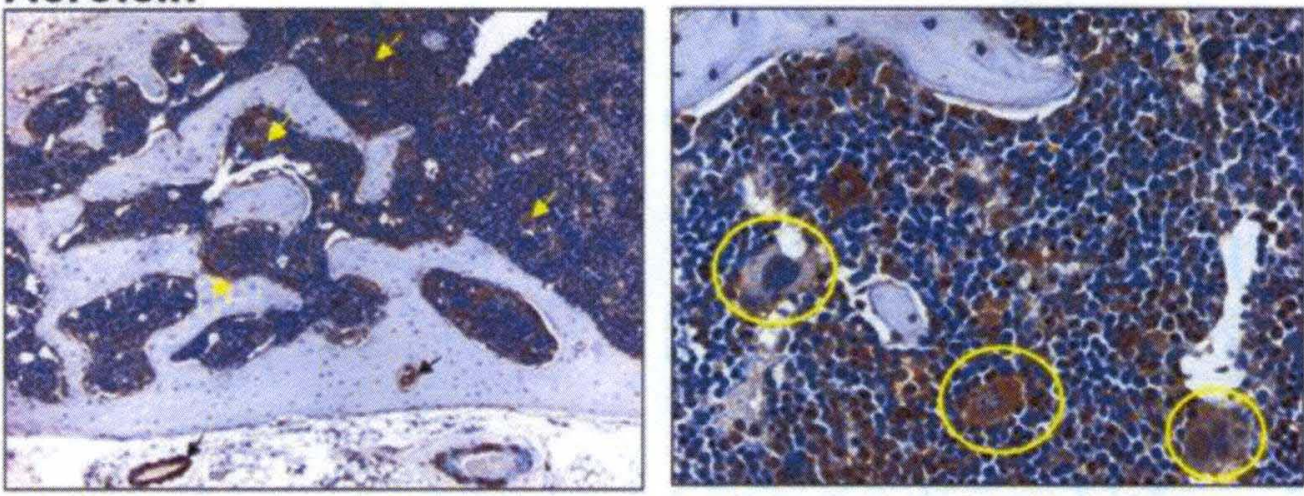

IgG controls:

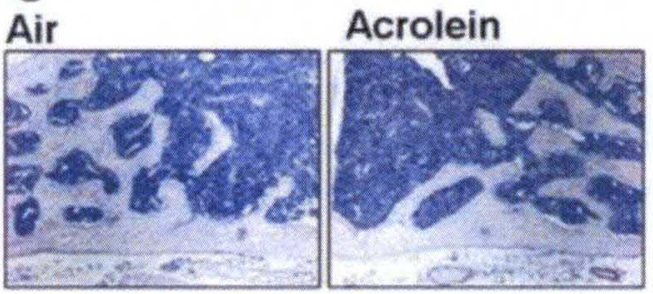


Figure 6: Formation of protein-acrolein adducts. Western blot analyses of protein-acrolein adducts in A, plasma or B, bone marrow extracts obtained from mice breathing air or $1 \mathrm{ppm}$ acrolein for 4 days $(6 \mathrm{~h} / \mathrm{d})$. Amido-black stain (plasma) and actin detection (bone marrow) were used as loading controls. C, Bone marrow immunohistochemistry of acrolein antibody staining, air $v$. acrolein inhalation. Data are presented as fold increase of protein-acrolein adducts after acrolein exposure compared with air-exposed mice ( $\left.{ }^{*} p<0.05 ; n=4-5\right)$. 


\section{Endothelial dysfunction and NO signaling}

The number of circulating Flk $-1^{+} / \mathrm{Sca}-1^{+}$cells is in continuous flux due to the competing processes of mobilization (e.g., bone marrow/spleen) and recruitment to sites of injury (e.g., endothelium). To determine if the acrolein-induced decrease in circulating Flk $-1^{+} / \mathrm{Sca}-1^{+}$cells was due to increased recruitment to vascular sites of injury, endothelium function was measured in isolated aorta following exposures. No evidence of frank vascular smooth muscle or endothelial cell dysfunction was found after $1 \mathrm{ppm}$ acrolein exposure $(6 \mathrm{~h} / \mathrm{d} \times 4 \mathrm{~d}$; Table 9), which is consistent with a previously published study using $1 \mathrm{ppm}$ acrolein exposure in C57BL/6 mice ${ }^{153}$. In contrast, brief exposure of mice to 5 ppm acrolein (6h) induced a modest, yet significant, rightward shift in the acetylcholine-mediated vasorelaxation in phenylephrine-precontracted aorta indicating endothelial dysfunction (Fig. 7A; Table 9). There was no change in total percentage of NO-donor-mediated (sodium nitroprusside, SNP) relaxation, although there was a significant leftward shift in aortic sensitivity to SNP $\left(\mathrm{EC}_{50}\right.$ : air, $16 \pm 3 \mathrm{nM}$; acrolein, $9 \pm 1 \mathrm{nM}, \mathrm{n}=8,8, p<0.05$; Table 9) - further indicating an endothelium-specific dysfunction. 
Table 9

Vascular effects of air or acrolein exposure in mice.

Air Acrolein, 1ppm Air Acrolein, $5 \mathrm{ppm}$

Phenylephrine (PE)

\begin{tabular}{lllll} 
Tension (mg) & $738 \pm 74$ & $659 \pm 62$ & $1037 \pm 156$ & $723 \pm 83$ \\
Active Stress (mN/mm²) & $8.9 \pm 0.9$ & $8.1 \pm 1.2$ & na & na \\
EC 5 (nM) & $149 \pm 15$ & $149 \pm 15$ & $151 \pm 33$ & $160 \pm 26$ \\
pD $_{2}$ & $6.84 \pm 0.05$ & $6.84 \pm 0.05$ & $6.88 \pm 0.09$ & $6.83 \pm 0.07$ \\
Acetylcholine (ACh) & & & & \\
Relaxation (\% PE) & $-63 \pm 5$ & $-64 \pm 7$ & $-66 \pm 8$ & $-66 \pm 3$ \\
EC 5 (nM) & $136 \pm 21$ & $195 \pm 82$ & $113 \pm 20$ & $180 \pm 24^{*}$ \\
pD $_{2}$ & $6.92 \pm 0.09$ & $6.92 \pm 0.15$ & $7.00 \pm 0.10$ & $6.77 \pm 0.06^{\dagger}$ \\
Sodium Nitropnusside (SNP) & & & \\
Relaxation (\% PE) & $-121 \pm 4$ & $-121 \pm 6$ & $-103 \pm 3$ & $-104 \pm 4$ \\
EC 50 (nM) & $15 \pm 3$ & $18 \pm 3$ & $16 \pm 3$ & $9 \pm 1^{*}$ \\
pD2 & $7.91 \pm 0.10$ & $7.80 \pm 0.07$ & $7.84 \pm 0.09$ & $8.08 \pm 0.06^{*}$ \\
\hline
\end{tabular}

Male, 12-14 week old C57BL/6 mice were exposed to air or acrolein (1ppm, 6h/d, 4d or $5 \mathrm{ppm}, 6 \mathrm{~h} / \mathrm{d}, 1 \mathrm{~d}$ ). Values are mean \pm SEM. Abbr. HI K*, $100 \mathrm{mM}$ potassium buffer, na, not available; $E C_{50}=$ effective concentration producing $50 \%$ response: $\mathrm{PD}_{2}$. tog $\left[E C_{50}\right]::$ - $p \leq 0.05$ vs. matched air control $(n=7.8$ mice/group); $0.10>p>0.05$ vs. matched-air control. 
To examine whether acrolein-induced endothelial dysfunction was due to changes in nitric oxide (NO) bioavailability, we examined changes in plasma of the stable end products (nitrate and nitrite) of the I-arginine/nitric oxide biosynthetic pathway otherwise known as $\mathrm{NO}_{\mathrm{x}}$, total eNOS, and the phosphorylation status of eNOS and Akt, which are critical mediators of endothelial signaling and function (Fig. 8). Acrolein exposure at $1 \mathrm{ppm}(6 \mathrm{~h} / \mathrm{d} \mathrm{x}$ $4 \mathrm{~d}$ ) or $5 \mathrm{ppm}\left(6 \mathrm{~h}\right.$ ) significantly decreased plasma $\mathrm{NO}_{\mathrm{x}}$ levels by $15 \%$ (air: $100 \pm 8$ $\%$; acrolein: $85 \pm 4 \% ; n=8,8 ; p<0.05$ ) or $22 \%$ (air: $100 \pm 8 \%$, acrolein; $78 \pm 4 \%$, $\mathrm{n}=8,8 ; p<0.05$ ), respectively (Fig. 7 C). The acrolein-induced suppression of plasma $\mathrm{NO}_{x}$ level after 4-day acrolein exposure was reversed by 7 days of recovery in acrolein-free air (Fig. 7A). Similarly, the recovery of plasma $\mathrm{NO}_{x}$ level coincided with a return of circulating Flk- $1^{+} / \mathrm{Sca}-1^{+}$cell numbers in acroleinexposed mice to the air control level (Fig. 4F).

Because acrolein exposure decreased both plasma $\mathrm{NO}_{x}$ and Flk-1 ${ }^{+} / \mathrm{Sca}-1^{+}$ cell levels, eNOS protein content was measured in lysates of lung, heart and aorta (Fig. 7C) by Western blotting. Additionally, VEGFR-2 abundance was measured by Western blotting in bone marrow lysates. As shown in Figure 7C, acrolein exposure ( $1 \mathrm{ppm} ; 6 \mathrm{~h} / \mathrm{d} \times 4 \mathrm{~d})$ did not alter eNOS protein abundance in lung, heart or aorta, nor did it change VEGFR-2 protein level in the bone marrow. 
Figure 7

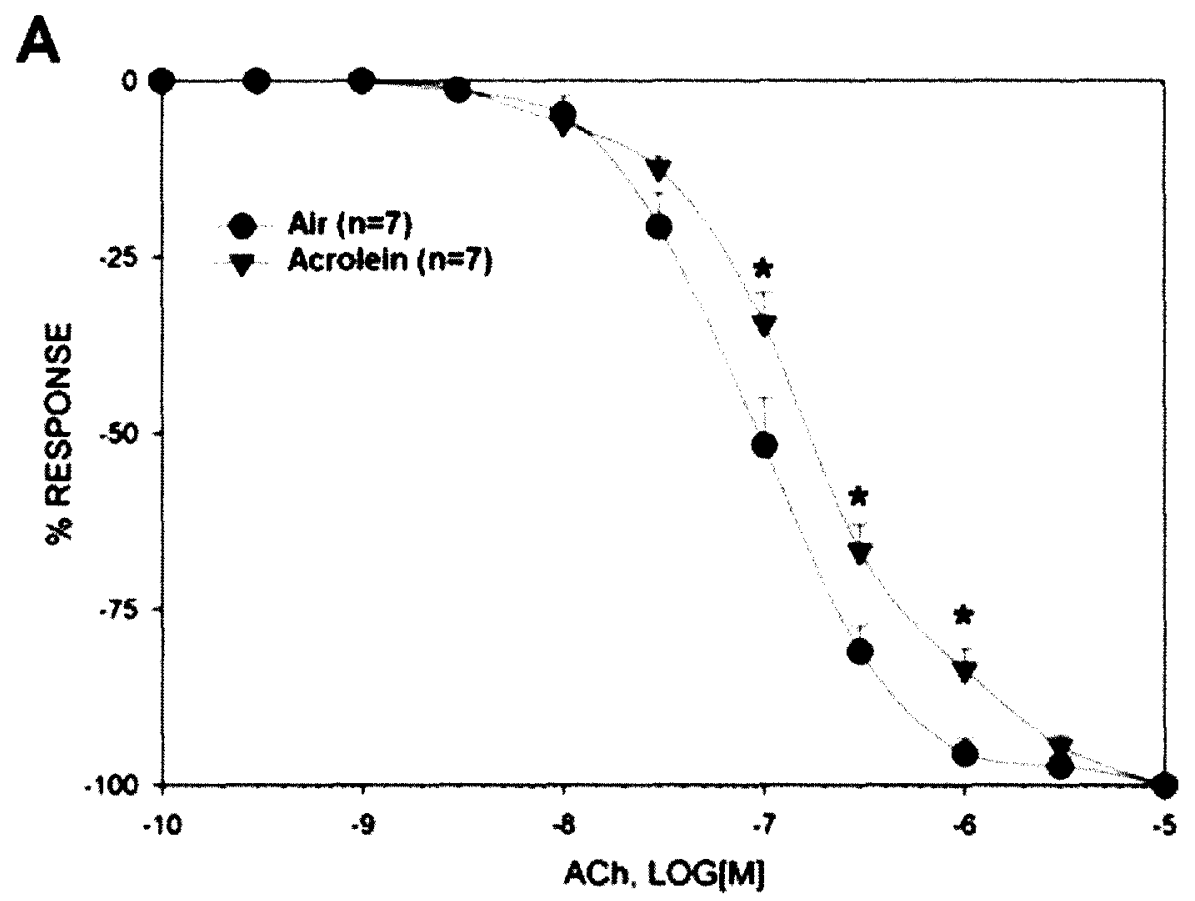

B

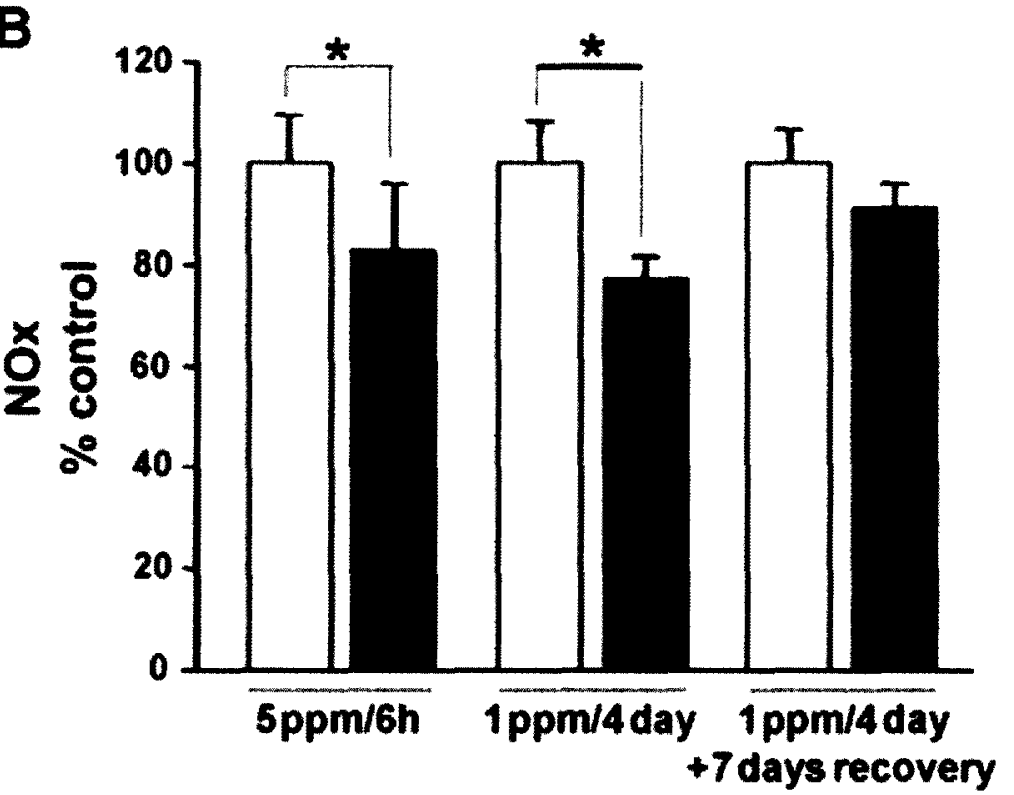



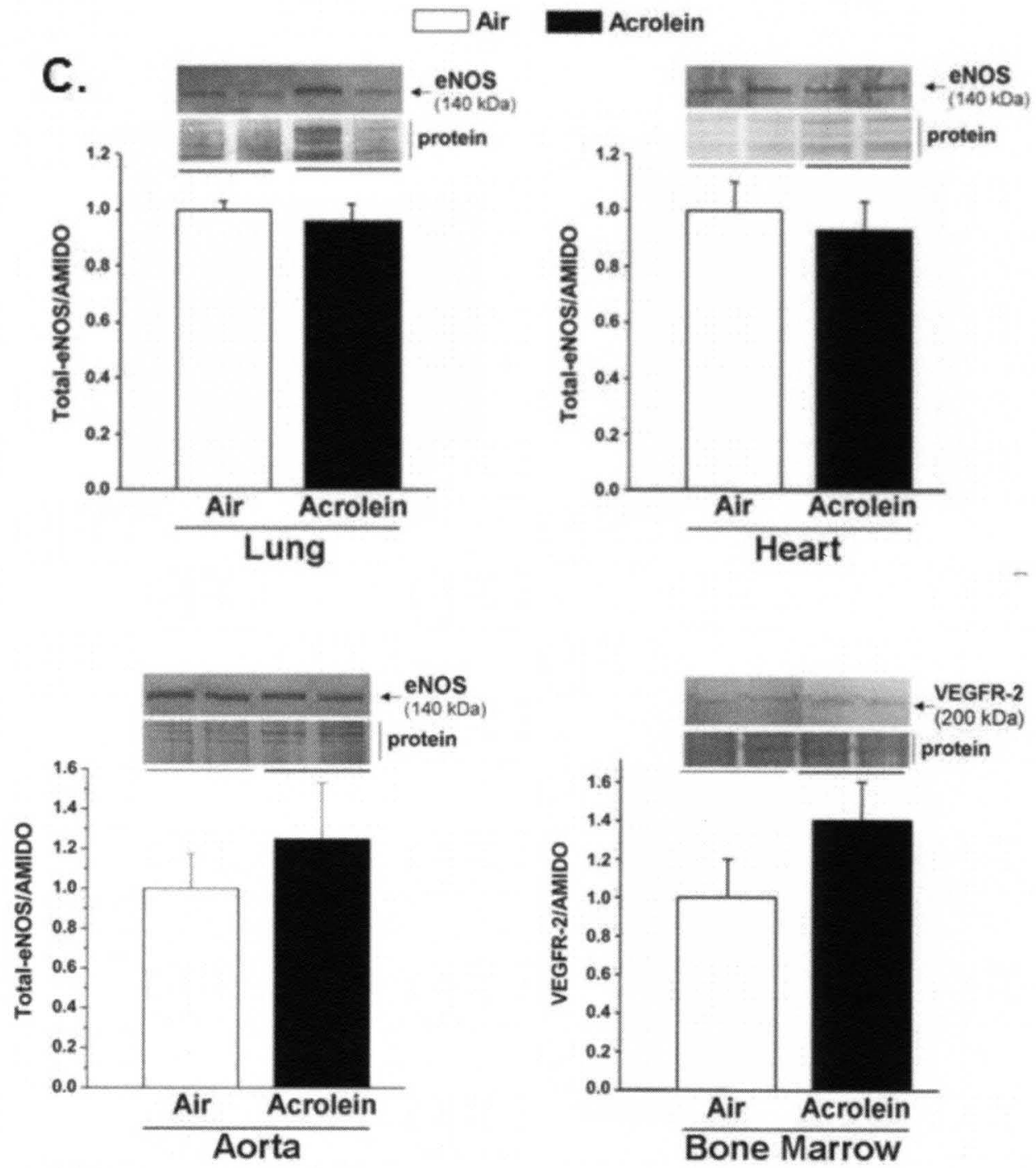
Figure 7: Endothelial response to acrolein exposure. A, Endothelial function assay from aorta of mice exposed to $5 \mathrm{ppm} 6 \mathrm{hr}$ acrolein $\left(n=4,{ }^{*} p<0.05\right) \mathrm{B}$, $\mathrm{NO}_{\mathrm{x}}$ levels in plasma of mice breathing filtered air or acrolein $(n=8$, * $p<0.05)$. C, Western blot analyses of eNOS or VEGFR2 in lysates of lung, heart, aorta or bone marrow of mice breathing filtered air or $1 \mathrm{ppm}$ acrolein $(6 \mathrm{~h} / \mathrm{d}, 4 \mathrm{~d})$. Group densitometry data are presented as mean \pm $\operatorname{SEM}(n=4) .{ }^{*} p<0.05$. 


\section{Figure 8}

A
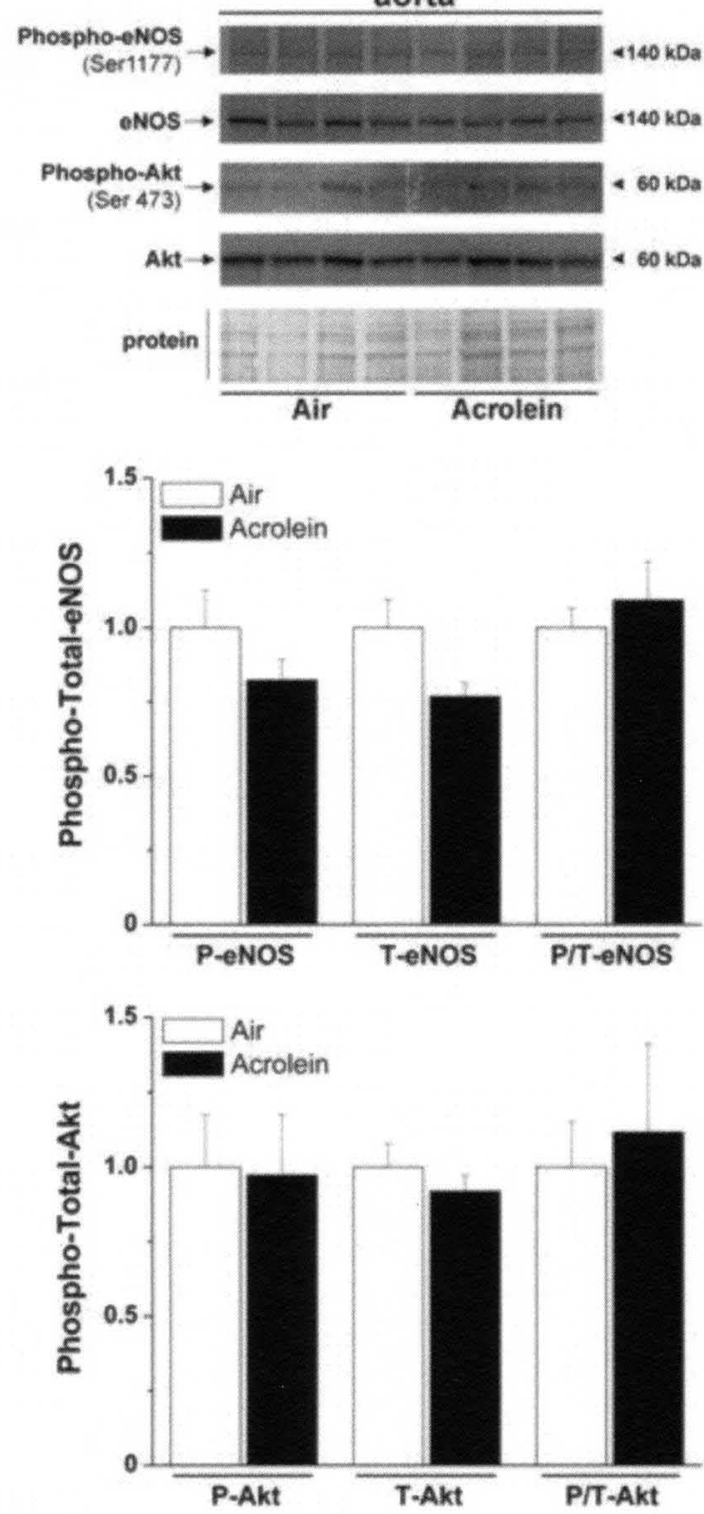

B
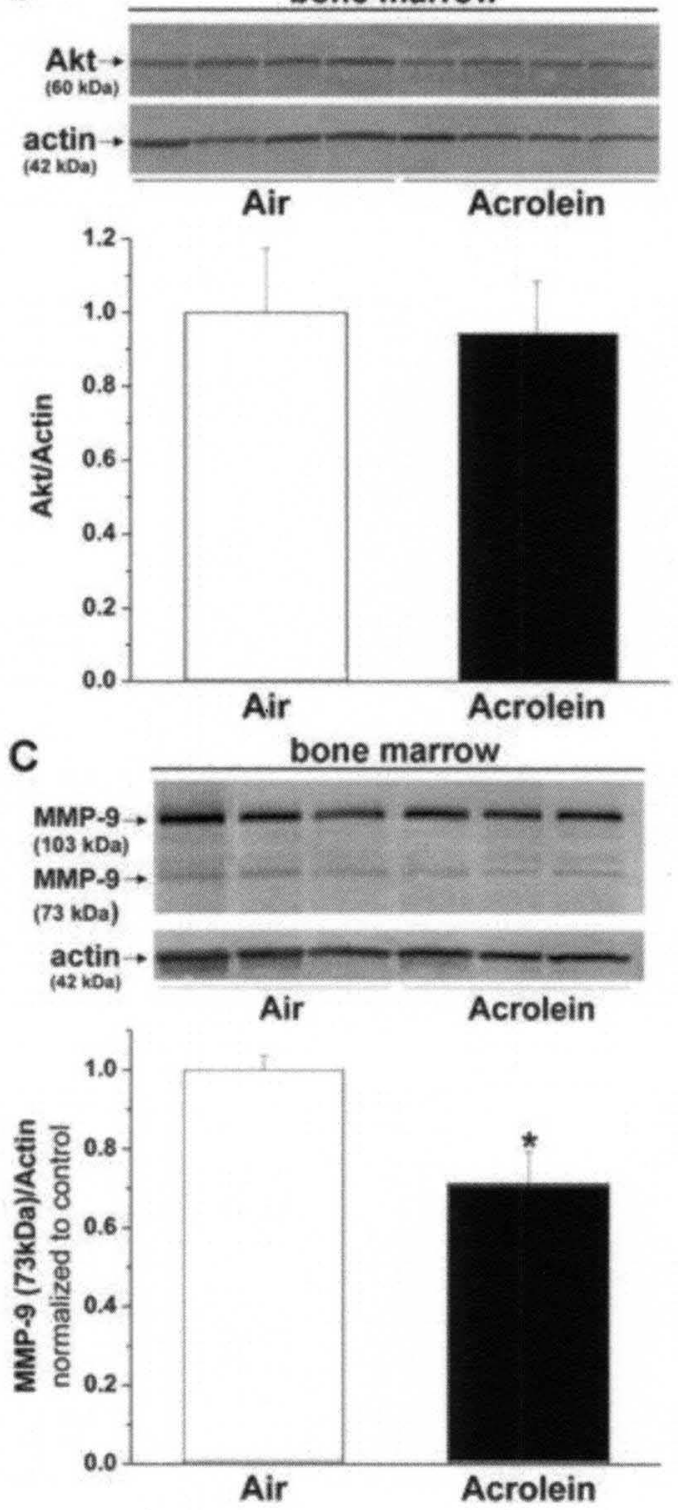
Figure 8: Effects of acrolein on enzymatically important constituents of EPC mobilization. A, Representative Western blots of phospho-eNOS (Ser1177), phospho-Akt (Ser473), eNOS and Akt in lysates of aortas obtained from animals exposed to air or Acrolein (5 ppm/6h) B, Akt and C, MMP-9 in lysates of bone marrow obtained from animals exposed to air or acrolein ( 5 $p p m / 6 h)$. Group data are presented as mean \pm SEM, $n=4$. 


\section{VEGF+AMD3100-induced mobilization of Flk-1 ${ }^{+} / \mathrm{Sca}-1^{+}$cells}

Because acrolein exposure decreased circulating Flk $-1^{+} / \mathrm{Sca}-1^{+}$cells in the absence of frank aortic endothelial dysfunction, we tested if acrolein perturbed progenitor cell mobilization. Acrolein alone (1 ppm, 4d) significantly decreased Flk $-1^{+} /$Sca- $1^{+}$cells compared with air controls (air + saline: $1.5 \pm 0.3$ cells $/ \mu \mathrm{L}$; acrolein + saline: $0.7 \pm 0.1$ cells $/ \mu \mathrm{L} ; n=4,4 ; p<0.05$; Fig. 9A). As shown before, VEGF+AMD3100 treatment led to a 3 -fold increase in circulating $\mathrm{Flk}-1^{+} / \mathrm{Sca}-1^{+}$ cells ${ }^{159}$. Acrolein inhalation significantly and specifically impeded VEGF+AMD3100-induced Flk-1 ${ }^{+} / \mathrm{Sca}-1^{+}$mobilization (normalized to air control: air+VEGF+AMD3100: $3.0 \pm 0.4$ cells/ $\mu$ L; acrolein+VEGF+AMD3100: $0.4 \pm 0.1$ cells/ $\mu \mathrm{L}, \mathrm{n}=8,8 ; p<0.05 ;$ Fig. 9A). Although VEGF+AMD3100 treatment significantly increased Sca- $1^{+}$cells (normalized to air control: air+VEGF+AMD3100: $2.8 \pm 0.4$ cells/ $\mu$ L; acrolein+VEGF+AMD3100: $2.9 \pm 0.4$ cells/ $\mu \mathrm{L}, \mathrm{n}=8,8$ ) and overall white blood cell counts, indicating general mobilization of both stem cells and leukocytes, these effects were unaltered by acrolein exposure (Table 10), indicating that acrolein specifically decreased the endothelial progenitor cell population.

Co-treatment with VEGF+AMD3100 is known to modify mobilization without changing bone marrow cell function ${ }^{159}$. Treatment with VEGF+AMD3100 did not alter aortic eNOS or Akt protein levels as analyzed by Western blotting regardless of exposure (Fig. 9B-C).

Our results indicate that acrolein at $1 \mathrm{ppm}$ inhibits mobilization of Flk-1 $1^{+} / \mathrm{Sca}-$ $1^{+}$cells via diminished NO bioavailability and impaired VEGF/ CXCR4 signaling. 
Henceforth, we studied VEGF signaling in aortas isolated from air- or acrolein- (1 $\mathrm{ppm}, 6 \mathrm{~h} / \mathrm{d} \times 4 \mathrm{~d})$ exposed mice. Aortas were incubated ex vivo with VEGF (20 ng/ $\mathrm{mL}$ ) for $15 \mathrm{~min}$ and phosphorylation status of Akt (Fig. 9D), eNOS (Fig. 9E) and ERK (Fig. 9F) proteins was analyzed. In control aortas, VEGF stimulated phosphorylation of Akt (2-fold) and eNOS (2-fold) - an effect absent in aortas of acrolein-exposed mice (Figs. 9D and 9E). Although VEGF-induced phosphorylation of ERK was not influenced by inhalation exposure, acroleinexposed aortas had a significantly greater level of basal phospho-ERK (p42/44) (Fig. 9F). These findings indicated that acrolein exposure significantly impaired VEGF/ CXCR4 signaling - an effect that could account for the diminished levels of basal and VEGF+AMD3100-mobilized Flk-1 ${ }^{+} / \mathrm{Sca}-1^{+}$progenitor cells, as well as, the decreased plasma $\mathrm{NO}_{x}$ level 
Figure 9

A
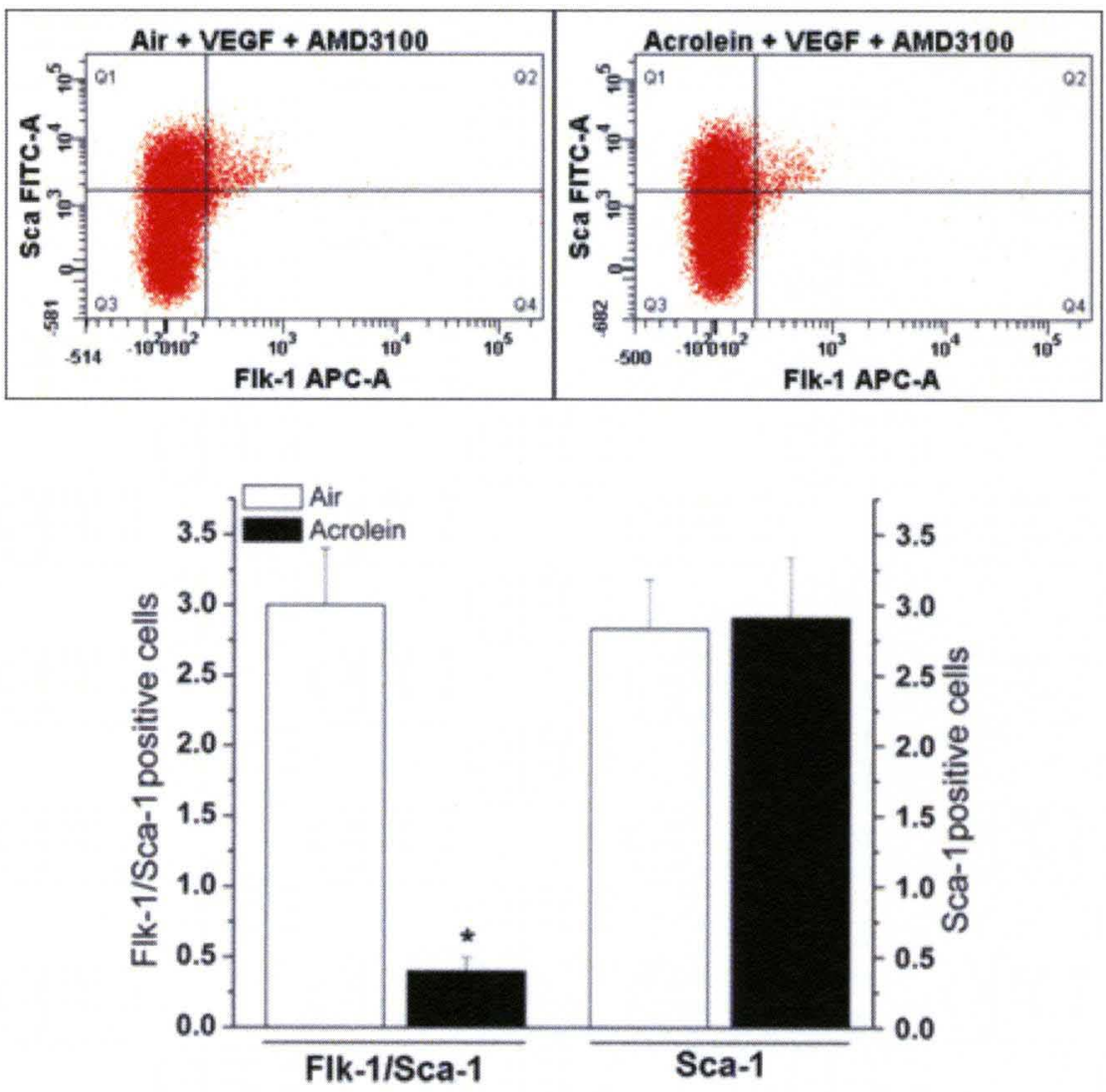
B
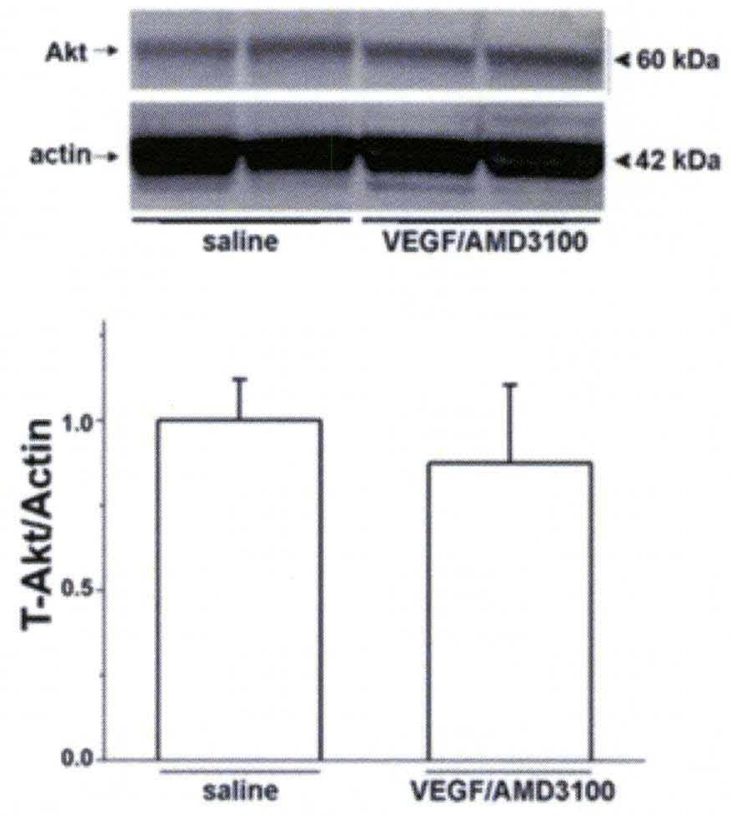

D

E
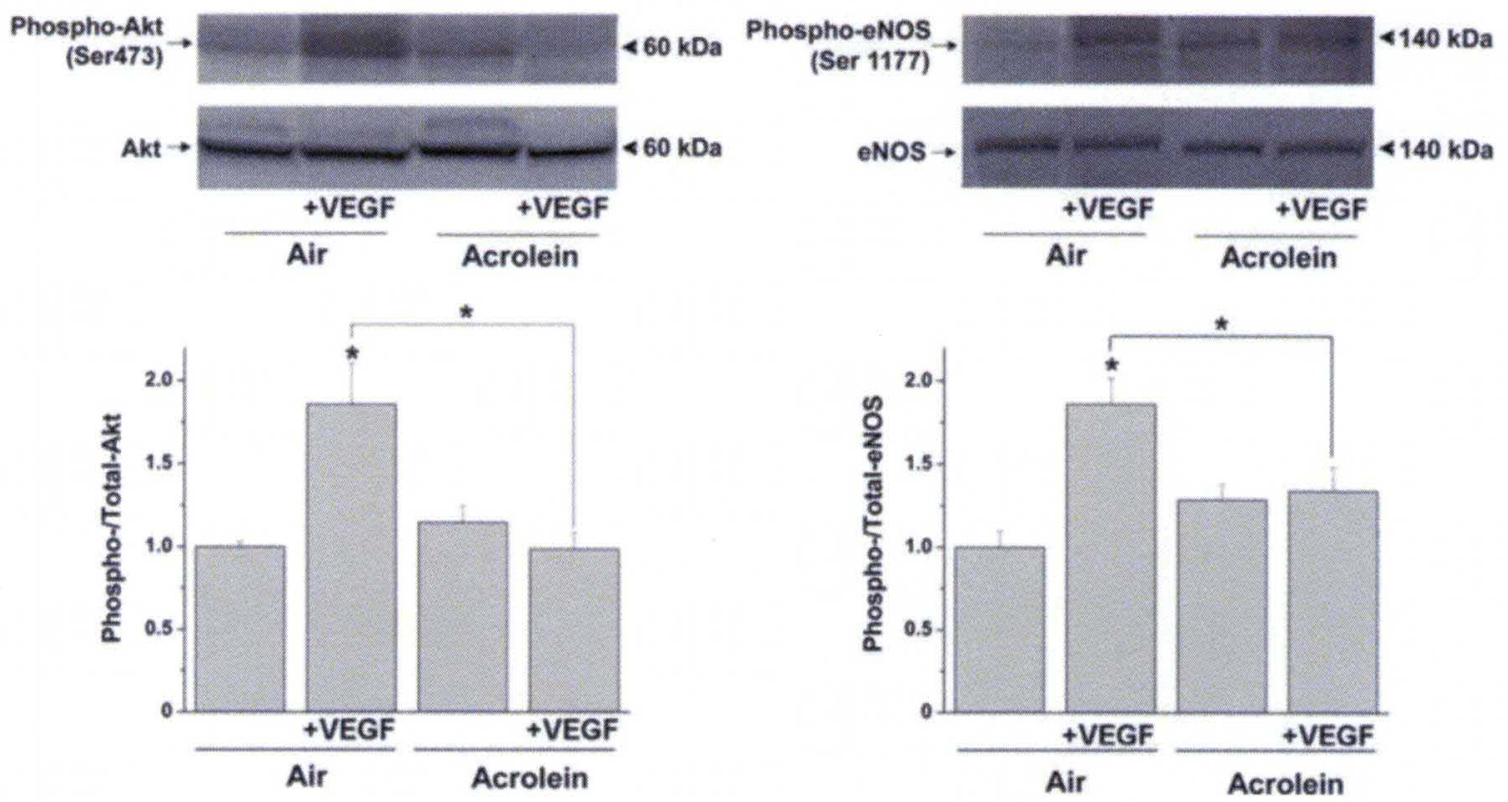
F

Phospho-

(Thr 202/Tyr 204) p44 $\longrightarrow$
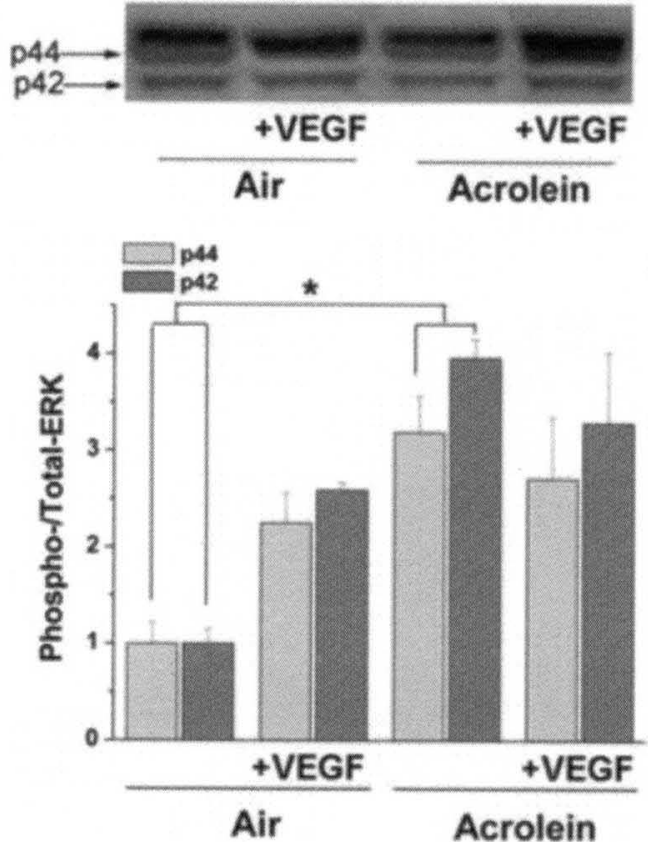


\section{Figure 9: Effect of acrolein on the mobilization of Flk-1 ${ }^{+} / \mathrm{Sca}-1^{+}$cells. A,}

Representative two color (Flk-1 and Sca-1) flow cytometry dot plots (upper panel) of circulating cells in the peripheral blood of mice breathing filtered air or $1 \mathrm{ppm}$ acrolein (6h/d, $4 \mathrm{~d})$ after combination of VEGF/AMD3100 treatment. Levels of Flk $-1^{+} / \mathrm{Sca}-1^{+}$cells per $\mu \mathrm{l} \mathrm{blood} \mathrm{(left} \mathrm{y}$-axis) and Sca$1^{+}$cells (right y-axis; fold-change relative to air control) of mice breathing filtered air or $1 \mathrm{ppm}$ acrolein $(6 \mathrm{~h} / \mathrm{d}, 4 \mathrm{~d})$ after treatment with VEGF/AMD3100 (* $p<0.05, n=8)$. B, Representative Western blots and densitometric analysis of Akt in bone marrow lysates obtained from mice after saline or VEGF/AMD3100 treatment $(n=4)$. C, Representative Western blots and densitometric analysis of eNOS in lysates of aortas obtained from mice breathing air or acrolein (1 ppm, 6h/d, 4d) after saline or VEGF+AMD3100 treatment ( $n=4)$. D-F, Analysis of VEGF signaling in aortas isolated from mice breathing air or acrolein (1 ppm, 6h/d, 4d) and treated with VEGF in autologous plasma for $15 \mathrm{~min}$. Representative Western blots and analysis of membranes probed for $D$, phospho-Akt (Ser473)/total Akt; E, phospho-eNOS (Ser1177)/total eNOS; and F, phospho-ERK (Thr202/Tyr204) /total ERK ( $n=3-7$; * $p<0.05)$. 


\section{Table 10}

Complete blood counts in mice exposed to air or acrolein

\begin{tabular}{|c|c|c|c|c|}
\hline & \multicolumn{2}{|c|}{+ solne } & \multicolumn{2}{|c|}{ +VEGF+ALO3100 } \\
\hline & $\overline{\text { Aur }}$ & Acrolen, $1 \mathrm{ppm}$ & $\overline{\text { Aur }}$ & Acrolein, Ippm \\
\hline WBC & $1365 \pm 210$ & $2137 \pm 368^{*}$ & $7630 \pm 810^{\circ}$ & $8030 \pm 475$ \\
\hline NE• & $422 \pm 79$ & $497 \pm 179^{\prime \prime}$ & $2345 \pm 362$ & $2821 \pm 280^{\prime}$ \\
\hline LY* & $897 \pm 165$ & $1600 \pm 192^{*}$ & $5042 \pm 494^{*}$ & $4981+285^{t}$ \\
\hline $\mathrm{MO}^{*}$ & $35 \pm 11$ & $61 \pm 32^{\circ}$ & $232 \pm 17$ & $220 \pm 16^{t}$ \\
\hline $\mathrm{RBC}^{\mathrm{D}}$ & $672 \pm 080$ & $868 \pm 0.33$ & $7.94 \pm 046$ & $832 \div 0.47$ \\
\hline $\mathrm{HCl}(\%)$ & $32.2 \pm 23$ & $392 \pm 15$ & $349 \pm 19$ & $371 \pm 22$ \\
\hline $\mathrm{Hb}^{4}$ & $91 \pm 12$ & $119 \pm 06$ & $10.8 \pm 0.7$ & $111 \pm 05$ \\
\hline MCV' & $447 \pm 07$ & $451 \pm 02$ & $445 \pm 03$ & $442 \pm 04$ \\
\hline $\mathrm{MCH}^{*}$ & $133 \pm 03$ & $138 \pm 01$ & $13.4 \pm 0.2$ & $135 \pm 0.3$ \\
\hline MCHCe & $29.9 \pm 0.5$ & $30.5 \pm 0.3$ & $30.8 \pm 0.9$ & $30.2 \pm 0.5$ \\
\hline ROW (\%) & $165 \pm 03$ & $173 \pm 02$ & $178 \pm 0.2$ & $173 \pm 03$ \\
\hline PLT: & $799 \pm 122$ & $858 \pm 76$ & $917 \pm 91$ & $809 \pm 78$ \\
\hline MPV & $44 \pm 01$ & $42 \pm 0.1$ & $44 \pm 01$ & $4.2 \pm 0.1$ \\
\hline
\end{tabular}

Male, 12-14 week old mice were exposed to arr or $1 \mathrm{ppm}$ acrolein (6hd, $4 \mathrm{~d}, \mathrm{n}=8$ miceigroup) Velues are mean \pm SEM Abbr WBC, white blood cells. NE, neutrophils. LY, lymphocytes, MO, monocytes, $\mathrm{RBC}$, red blood cells, $\mathrm{HCl}$, hematocrit, $\mathrm{Hb}$, hemoglobin, MCV, mean corpuscular volume, $\mathrm{MCH}$, mean corpuscular hemoglobin, MCHC, mean corpuscular hemoglobin concentration, RDW, red cell distribution with; PLT, platelets, MPV, mean platelet volume Unts $=\left[\times 10^{3} / \mu \mathrm{L}\right]^{\circ}=\left[\times 10^{6} / \mu \mathrm{L}\right]^{c}=[\mathrm{g} / \mathrm{dL}]^{\circ}$ $=[\mathrm{fl}]]^{*}=[\mathrm{pg}]{ }^{*}, \rho<005$ vs air-matched group ${ }^{\dagger}, p<005$ vs Aur+VEGF/AMO3100 matched group 


\section{Discussion}

Results of the current study showed that inhalation of acrolein suppressed the level of Flk $-1^{+} / \mathrm{Sca}-1^{+}$cells in the peripheral blood and prevented their mobilization by VEGF/SDF-1. The effects of acrolein were specific because acrolein decreased Flk- $1^{+} / \mathrm{Sca}-1^{+}$cells without affecting the level of Sca- $1^{+}$cells, indicating a unique sensitivity of this heterogeneous cell population to acrolein. Effects of acrolein inhalation were, however, transient, and recovery in an acrolein-free environment for 7 days led to complete restoration of the level of these cells in the peripheral blood. Moreover, the decrease in Flk $-1^{+} / \mathrm{Sca}-1^{+}$cells was associated with decreased plasma $\mathrm{NO}_{x}$ level, prevention of VEGF/CXCR4induced mobilization of Flk-1 ${ }^{+} / \mathrm{Sca}-1^{+}$cells and inhibition of VEGF-induced Akt and eNOS phosphorylation - a constellation of changes impinging on vascular function and repair.

Our results also indicated that the bone marrow could be a specific locus of acrolein action. We found that acrolein inhalation increases accumulation of protein-acrolein adducts in the plasma and the bone marrow, suggesting that despite its high reactivity and rapid metabolism, acrolein was delivered from the lung into the systemic circulation and to distal vascular sites. Our previous studies have shown that exposure to tobacco smoke or acrolein resulted in the formation of protein-acrolein adducts in non-pulmonary sites ${ }^{153,160}$. Thus, acrolein appeared to cross from the lungs and directly induce bone marrow toxicity. 
Although acrolein inhalation decreased levels of circulating Flk-1 $1^{+} / \mathrm{Sca}-1^{+}$ cells, it increased the number of bone marrow-derived Flk- $1^{+} / \mathrm{Sca}-1^{+}$cells that accumulated acLDL and were positive for Ulex lectin binding in culture. Because the number of cells that grow out of the bone marrow on fibronectin-coated dishes is indicative of their population in the bone marrow ${ }^{159}$, it appeared likely that exposure to acrolein increased proliferation of $\mathrm{Flk}-1^{+} / \mathrm{Sca}-1^{+}$cells in the bone marrow, while preventing their egress into the circulation. Alternatively, decreased mobilization by acrolein could indirectly result in the expansion of the bone marrow population of these cells. Nevertheless, this increase in levels of Flk $-1^{+} / \mathrm{Sca}-1^{+}$cells in the bone marrow indicated that acute acrolein exposure did not permanently impair the growth or viability of these cells but that it prevented their mobilization from the bone marrow. We suggest that this defect could be due to alterations in VEGF/SDF-1 signaling, but it also may be related to other specific processes such as cell release from the bone marrow stroma by matrix metalloproteases (MMPs), which is a NO-dependent process. Indeed, our measurements showed that exposure to acrolein is associated with a decreased level of active MMP-9 (73 kDa) in bone marrow lysate (Fig. 8C).

Depletion of Flk- $1^{+} / \mathrm{Sca}-1^{+}$cells in the peripheral blood in acrolein-exposed mice could also be due induction of cell death. Our measurements showed that even brief exposure (2h) to acrolein resulted in a significant increase in the markers of cell death within the circulating Flk-1 $1^{+} / \mathrm{Sca}-1^{+}$but not the Sca- $1^{+}$cell population (Fig. 4). These observations reinforce the view that the $\mathrm{Flk}-1^{+} / \mathrm{Sca}-1^{+}$ population is uniquely sensitive to acrolein; however, persistent suppression of 
the steady-state levels of circulating Flk- $1^{+} / \mathrm{Sca}-1^{+}$cells (Fig. 4) implies that the primary defect was in the bone marrow because the depletion of these cells, due to increased cell death or increased recruitment to sites of injury, was not adequately compensated via mobilization from the bone marrow.

Because acrolein is one of the most reactive and toxic components of tobacco smoke, it is not surprising that many effects we observed with acrolein inhalation are consistent with findings of tobacco smoke exposure. Our observation that acrolein induced endothelial injury was consistent with evidence showing that exposure to combustion products generated by automobile exhaust $^{148}$ or tobacco smoke ${ }^{146,147}$ impairs endothelial function. Previous studies show that chronic smoking decreases the number of endothelial progenitor cells (EPCs) and that smoking cessation restores EPC levels in human subjects ${ }^{161}$. The reversible effects of smoking are similar to the reversible effects of acrolein inhalation (see Fig. 4F), as well as particulate matter $\left(\mathrm{PM}_{2.5}\right)$ exposure ${ }^{31}$. In contrast to chronic smoking, brief exposure to secondhand smoke increases EPC levels ${ }^{162}$. Although we studied low-dose $(0.5 \mathrm{ppm})$ and brief $(2 \mathrm{~h})$ exposures, we did not observe an increase in Flk $-1^{+} / \mathrm{Sca}-1^{+}$cells in acrolein-exposed mice. We speculate that the increase in EPCs upon brief exposure to secondhand smoke may be related to other combustion products such as $\mathrm{CO}^{163}$, which by inducing transient or pseudo-hypoxia could increase EPC mobilization. Yet, inhibition of VEGF signaling by secondhand smoke exposure ${ }^{164}$ is similar to the effect of acrolein (Fig. 9) indicating that some of the pathological effects of secondhand smoke could be mediated by acrolein. 
The levels of acrolein used in the current mouse exposure studies are relevant to those encountered by passive and active smokers as well as humans with occupations that include high level or chronic exposure to vehicle exhaust or smoke (e.g., bus drivers, bartenders, firefighters). Given the obvious lack of systemic toxicity (Tables $\mathbf{5}$ and $\mathbf{7}$ ) in mice, our observations suggested that acrolein at environmentally relevant levels could suppress circulating $\mathrm{Flk}-1^{+} / \mathrm{Sca}-$ $1^{+}$cell numbers without inducing overt toxicity. Moreover, it is important to point out that humans are exposed to acrolein not only from combustion, but also from foods and beverages, which contain high levels of acrolein ${ }^{165}$. In addition, acrolein is generated endogenously during lipid peroxidation and via myeloperoxidase activity at sites of inflammation ${ }^{166}$. Hence acrolein generated endogenously from distal inflamed tissues could also suppress $\mathrm{Flk}-1^{+} / \mathrm{Sca}-1^{+}$cell mobilization from bone marrow (and other sites) and decrease the circulating levels of these cells. Nevertheless, the pathophysiological significance of acrolein-induced changes in Flk $-1^{+} / \mathrm{Sca}-1^{+}$cells remains unclear and deserves additional assessment. Previous studies show that the circulating levels of these cells are increased acutely in response to injury and that chronic suppression of similar progenitor cells is associated with an elevated CVD risk in humans ${ }^{17}$. In our analyses, we measured considerable antigenic diversity within the Flk$1^{+} /$Sca- $1^{+}$population, which has characteristics of monocytes, T- and B-cells. However, most of these cells were $\mathrm{CXCR} 4^{+}$(Fig. $3 \mathrm{C}$ ) and they were mobilized by VEGF/AMD3100 which indicated that this population was likely to be recruited to the site of hypoxic or traumatic tissue injury. Moreover, the cells were also Id $1^{+}$ 
(Fig. 2E). Recent work suggests that Id1 is a selective marker of EPCs because ablation of 1d1 in bone marrow-derived cells reduces circulating EPC levels and induces significant defects in angiogenesis as $\mathrm{Id} 1^{+}$cells are incorporated in tumor neo-vessels ${ }^{167}$. Thus, the Flk-1/Sca-1 population affected by acrolein could be important for wound healing and angiogenesis.

Wound healing is a complex process. It involves the clearance of cell debris, regeneration of injured tissue, and the growth of new blood vessels. This process requires the recruitment of a diverse set of progenitor cells containing both monocytic ${ }^{168}$ and endothelial ${ }^{167}$ characteristics, which ultimately turn into macrophages and vascular cells to secrete proteases, cytokines and growth factors that promote growth of tissue-resident cells. Therefore, we speculate that suppression of this recruitable and pro-angiogenic cell population by acrolein could lead to deficits in wound healing capacity. Future work is required to identify the effects of acrolein on specific cell populations and how these interfere with individual steps in the wound healing response. 


\section{CHAPTER III}

\section{EFFECTS OF ACROLEIN ON ANGIOGENESIS}

\section{Introduction}

Angiogenesis and vasculogenesis are two processes responsible for vascular development in both adults and fetal gestation ${ }^{169}$. The process of angiogenesis is the development of new vessels from preexisting vessels, while vasculogenesis refers to the development of a primitive vessel frame work by stem and progenitor cells ${ }^{170}$. Angiogenesis is highly regulated and controlled by a balance of stimulators (e.g. vascular endothelial growth factor, angiopoetin-1, and erythropoietin) and inhibitors (e.g. angiostatin, platelet factor 4 , interferon- $\beta$ ) of vascular formation ${ }^{171}$. In ischemic diseases, both hypoxia and inflammation are fundamental for the stimulation of angiogenesis ${ }^{172}$. Several disease states such as Alzheimer's ${ }^{173}$, coronary artery disease ${ }^{174}$, arthrosclerosis ${ }^{175}$, and diabetes ${ }^{176}$ have decreased angiogenesis and wound healing ability. Diabetics often suffer from a plethora of angiogenic-related health issues retinopathy ${ }^{177}$, neuropathy ${ }^{178}$, nephropathy ${ }^{179}$, which can lead to ischemic ulcers and gangrene. Aside from diabetes, active and passive smokers are subject to increased cardiovascular health risks brought on by decreased angiogenesis ${ }^{180}$. Studies have shown smokers do not respond to ischemic injury or stimuli as do healthy 
non-smokers $^{181}$. Cigarette smoke exposure has been shown to decrease angiogenesis, both in vivo and in vitro ${ }^{182}$. The chemical(s) found in cigarettesmoke that affect angiogenesis in active smokers and those exposed to second hand smoke are yet to be identified. Angiogenesis was thought to develop solely from the sprouting of local endothelial cells, however, the discovery of endothelial progenitor cells (EPCs) revolutionized this dogma ${ }^{78}$. EPCs are vital for ongoing endothelial repair of damaged vessels ${ }^{136}$. Circulating EPCs incorporate into the sites of neovascularization and injury, improving endothelial function ${ }^{183}$. Previous studies have also shown active smokers have decreased numbers of circulating EPCs $^{184,185}$, which can account for decreased angiogenesis and cardiovascular health seen in smokers ${ }^{185}$. EPCs are positively correlated with wound healing and angiogenic ability ${ }^{186}$. Studies from our lab, presented in chapter II of this thesis show EPCs $\left(\mathrm{Flk}-1^{+} / \mathrm{Sca}-1^{+}\right)$are decreased in a time and dose dependent manner when mice were exposed to acrolein, much like the phenomenon seen in chronic smokers $^{187}$.

In this study we hypothesized that exposure to acrolein could prevent angiogenesis by preventing ischemic injury-induced mobilization of EPCs.

\section{Methods}

All Experimental procedures and protocols were reviewed and approved by the Institutional Animal Care and Use Committee of the University of Louisville, and conform to the NIH "Guide for the Care and Use of Laboratory Animals". 


\section{Tube forming assay}

Human Umbilical Vein Endothelial Cells (HUVECs) were cultured in endothelial basal media (Clonetics/Lonza) supplemented with $20 \%$ FBS (Invitrogen), human endothelial growth factor (hEGF), hydrocortisone, gentamycin/amphotericin B (GA) and bovine brain extract (BBE; SingleQuot $($, Clonetics/Lonza) under standard cell culture conditions $\left(37^{\circ} \mathrm{C}, 5 \% \mathrm{CO}_{2}\right)$. Cells were grown in $10 \mathrm{~cm}$ dishes until $80 \%$ confluent. Cells were treated with $0,2.5$, or $5 \mathrm{mM}$ acrolein in $5 \mathrm{~mL}$ of Hanks Buffering solution $\left(\mathrm{HBSS}^{+}\right.$) supplemented with $5 \mu \mathrm{M}$ glucose for $30 \mathrm{~min}\left(37^{\circ} \mathrm{C}, 5 \% \mathrm{CO}_{2}\right)$, while controls were incubated in $5 \mathrm{~mL}$ of $\mathrm{HBSS}^{+}$alone. Cells were washed with warm $\mathrm{HBSS}^{+}$and allowed to recover for $4 \mathrm{~h}$ in fresh media $\left(37^{\circ} \mathrm{C}, 5 \% \mathrm{CO}_{2}\right)$. Cell were then trypsinized and seeded in a 96 well plate $\left(1 \times 10^{4}\right.$ cell/well) coated with Matrigel $\otimes$ (BD Biosciences). Pictures were taken every $30 \mathrm{~min}$ of tube formation and counted for $6 \mathrm{~h}$ using Evos $®$ microscope.

\section{Acrolein inhalation}

Acrolein atmospheres were generated from a liquid refillable humidification tube (LFH, Kin Tek Laboratories, La Marque, TX, USA). Acrolein emission rate of the permeability tube was controlled by temperature, $1 \mathrm{ppm}$ acrolein levels were produced by placing tube in a hot water bath at a set temperature of $50^{\circ} \mathrm{C}$. Immersion of the permeability tube in the inert gas Nitrogen allowed for trace element of the acrolein to be emitted with high dosage accuracy. During exposure, acrolein concentration was continuously monitored using an in-line 
photo ionization detector (ppb RAE+, Rae Industries, Sunnyvale, CA, USA) upstream of the cage insert vapor delivery unit (Teague Enterprises, Inc.) mounted on a standard polycarbonate rat cage $(41 \mathrm{~cm} \times 34 \mathrm{~cm} \times 21 \mathrm{~cm} ; \approx 31 \mathrm{~L})$. Air or acrolein was distributed through a fine mesh screen at $3 \mathrm{lpm}$ by delivery units with a cyclone-type top that distributed air within $10 \%$ of the mean concentration at six locations in the cage (Scheme 6). Exposure cages were placed partially over heating pads $\left(\approx 22^{\circ} \mathrm{C}\right)$ to allow mice to select preferable temperature. Mice were exposed to $1 \mathrm{ppm}$ acrolein for 4 days $6 \mathrm{~h} / \mathrm{d}$ (995.7 $\pm 1.4 \mathrm{ppb}$ of) prior to induction of hindlimb ischemia (HLI) or to $2 \mathrm{ppm}$ acrolein for 4 days $(2138 \pm 5.4 \mathrm{ppb})$ prior to HLI. Acrolein inhalation was continued the day after induction of $\mathrm{HLI}$ in all study groups and perfusion recovery was followed by laser Doppler imaging. 
Scheme 6

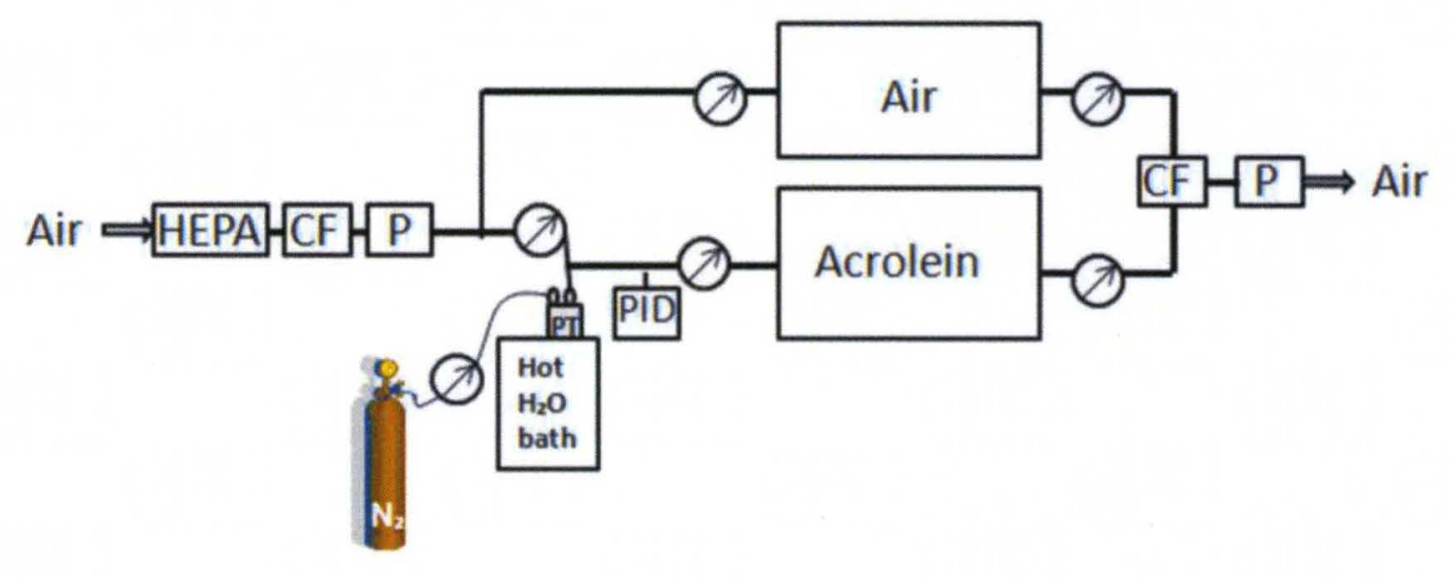




\section{Punch wound}

Male C57/BL6 mice at 12 weeks of age (Jackson Laboratories) were anesthetized with Isoflurane $1-3 \%$ in $100 \%$ oxygen at $1 \mathrm{~mL} /$ minute. Mice were shaved $24 \mathrm{~h}$ before punch wounds were induced dorsally. A double punch wound was made on the back between the shoulder blades using a $5 \mathrm{~mm}$ punch skin biopsy pin (Integra Miltex Inc, York, PA, USA). (Fig. 10A) 


\section{Figure 10}

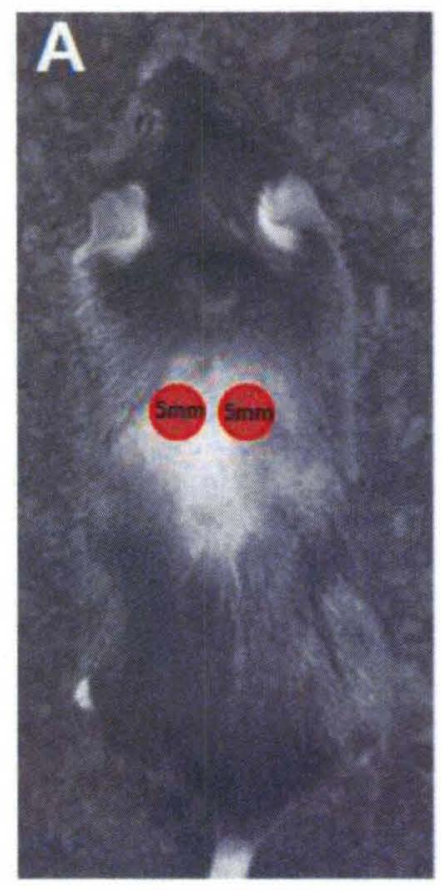

Figure. 10 punch wound model representative picture of $5 \mathrm{~mm}$ punch wound location 


\section{Hind limb ischemia}

Male C57/BL6 mice at 12 weeks of age (Jackson Laboratories) were anesthetized with isoflurane $1-3 \%$ in $100 \%$ oxygen at $1 \mathrm{~mL} /$ minute. Mice were shaved and then sensitive skin Nair (Church \& Dwight Co.,Princton, NJ, USA) applied to remove all hair on the lower limbs $24 \mathrm{~h}$ before surgery (Fig. 11A). Mice were anesthetized with isoflurane $1-3 \%$ in $100 \%$ oxygen at $1 \mathrm{~mL} /$ minute, the femoral artery was ligated distal of the femoral bifurcation and proximal to the ankle joint using 7-0 silk suture (Johnson \& Johnson Co., Ethicon, Cornelia, GA, USA), approximately $1 \mathrm{~cm}$ of femoral artery was excised between the ligation points (Fig.12B). Skin was closed using 5-0 polyethyl (Ethicon) discontinuous suture. Mice were given $0.05 \mathrm{mg} / \mathrm{kg}$ of buprenorphine for pain management 1 hour before surgery. Mice were allowed to recover for $24 \mathrm{~h}$ before starting acrolein inhalation. Mice were euthanized and changes in EPC levels were measured after surgery by flow cytometry (see Chapter 2). Perfusion recovery was measured on days $2,4,8,12$ or 18 after HLI surgery independent of inhalation exposures. 


\section{Figure 11}
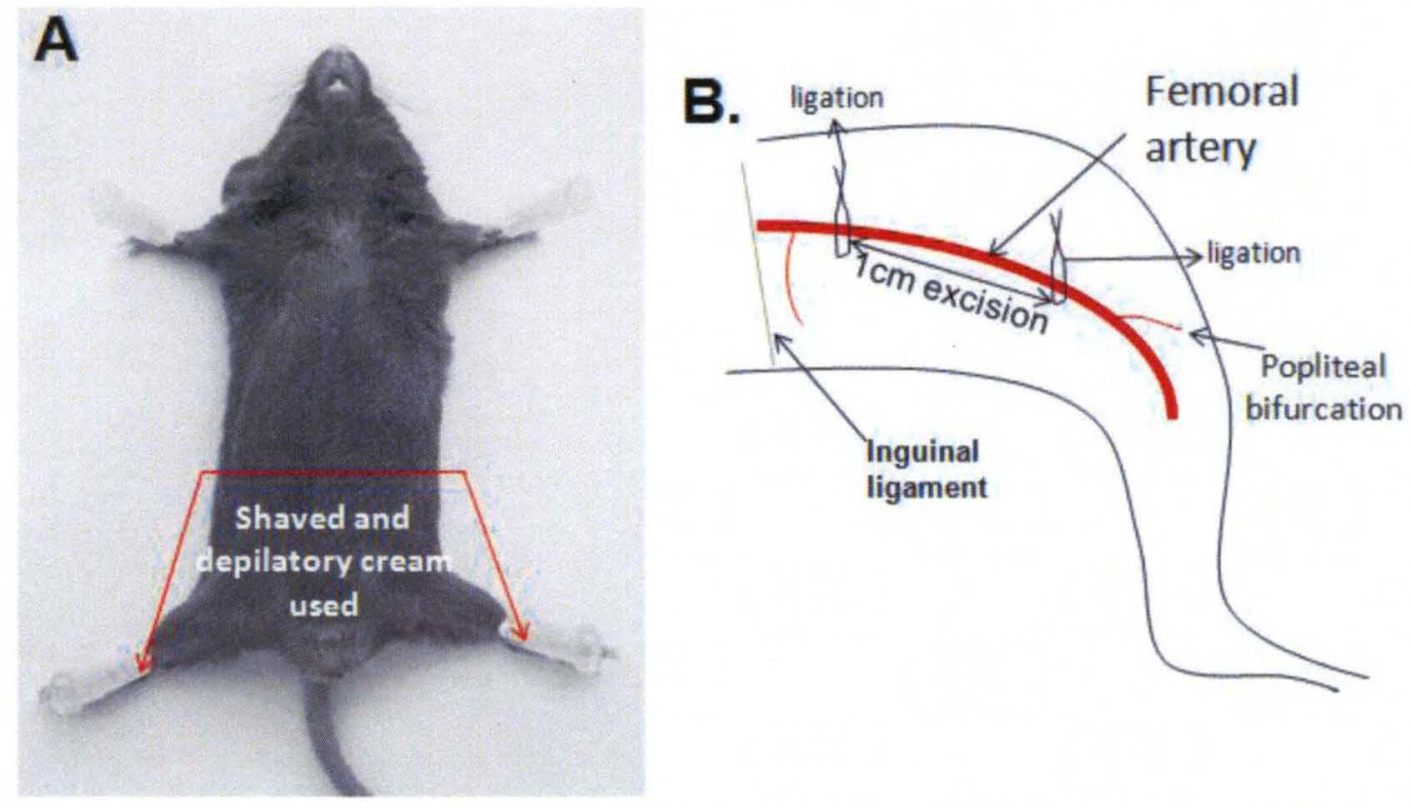

Figure 11. Representative pictures $\mathbf{A}$, shows transverse abdominal line and area shaved then depilatory cream used for hair removal before HLI surgery, B, shows a representation of the HLI surgery and excision of the femoral artery and ligation points. 


\section{Laser Doppler perfusion imaging}

Blood perfusion in the ischemic (right) and normal (left) hind limb was measured with laser Doppler perfusion imaging (LDPI) system (PIMII, Perimed Instruments, North Royalton, $\mathrm{OH}$ ). Low or no blood perfusions were displayed in dark blue, and the highest perfusion intervals were displayed in red. When laser light penetrates the tissue under study it is scattered or partly absorbed. Some of the scattered light returns to the tissue surface, where it is registered by a photo detector inside the instrument head. Information sent back to the instrument head which is read by the machine and provides information about the microcirulatory blood flow. According to the Doppler principle, light particles which hit moving blood cells undergo a change in wavelength/frequency otherwise known as Doppler shift. The perfusion can be calculated because the magnitude and frequency distribution of the Doppler shifted light are directly related to the number and velocity of blood cells but unrelated to their direction of movement. Perfusion data was shown as mean perfusion in volts. Mice were placed at a depth of $12 \mathrm{~cm}$ from the head of the PIM II on a black non-reflectant surface. The laser was allowed to warm up for $15-20 \mathrm{~min}$ before use. The machine was set on high resolution, with a set threshold voltage of 6 . Analysis of hind limb ischemia data compared ischemic to non-ischemic limbs and subtraction of average background voltage from each captured image. Data was presented as the perfusion ratio ischemic to non-ischemic limb. 


\section{Complete blood count}

After select exposures, $100 \mu \mathrm{l}$ of blood were used for complete blood count analysis (CBC; Hemavet 500, Coulter Counter, Oxford, CT).

\section{Histology}

Animals were anesthesized (pentobarbital; $40 \mathrm{mg} / \mathrm{kg}$ ). Whole thigh muscle including adductor longus, gracilis, adductor magnus and biceps femoris of both legs were harvested (Fig 12A-I). The gastronemius muscles were also harvested from both ischemic and non-ischemic limbs and fixed in $10 \%$ neutral buffered formalin (NBF) for $24 \mathrm{~h}$. Fixed tissue was paraffin-embedded and cut into $5 \mu \mathrm{M}$ thick sections and placed on slides. Sections were stained with UE-Lectin-FITC (1:50; Vector Laboratories, Burlingame, CA, USA) and anti- $\alpha-S m o o t h$ Muscle Actin-FITC (1:250; Sigma) antibody for $1 \mathrm{~h}$ at $37^{\circ} \mathrm{C}$. Slides were washed and nuclei were stained with DAPI (Molecular Probes, Invitrogen, Carlsbad, CA, USA). Auto-fluorescence was quenched with $0.1 \%$ Sudan black solution for 30 min at RT. Slides were again washed under running distilled water and cover slipped using Slow Fade ${ }^{\circledR}$ Gold anti-fade mounting reagent (Invitrogen). Capillary densities were calculated as the area of vessels positive for FITC-Lectin within each field. Arteriogenesis was calculated by counting the total number of $\alpha$-SMA positive vessels within each field. Slides were examined by fluorescent microscopy (Evos microscope 20X) in four different random fields for capillary area calculations, while seven random fields were taken for $\alpha$-SMA positive vessels. Pictures were analyzed using Nikon Elements software. 


\section{Figure 12}
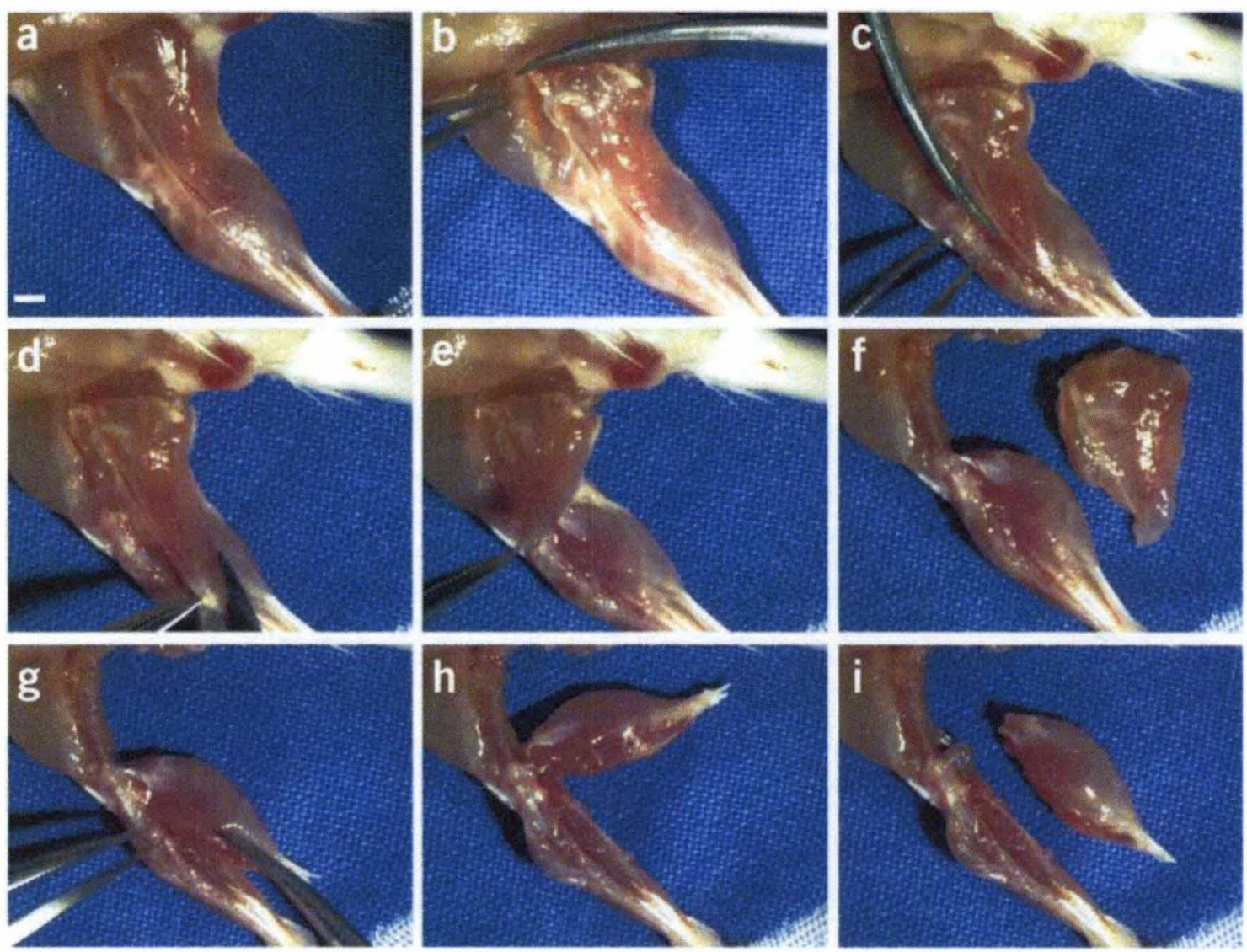

Figure 12. Representative pictures of A-I, removal of ischemic and non-ischemic muscle that is to be fixed, processed and stained for immunohistochemistry after HLI surgery. 


\section{Results}

\section{Tube forming assay}

To examine the effects acrolein has on angiogenesis, we first studied its effects on the spontaneous tube formation by endothelial cells. For this, HUVECs were cultured to $80 \%$ confluency, then treated with $\mathrm{HBSS}^{+}, 2.5$ or $5 \mu \mathrm{M}$ of acrolein in HBSS + for 30min. Acrolein decreased tube formation at both 2.5 and $5 \mu \mathrm{M}$ concentrations (Fig.13A-B). However, $2.5 \mu \mathrm{M}$ acrolein treated HUVECs recovered to that of control by the $6 \mathrm{~h}$ time point, while the tube formation plateaued at $3 \mathrm{~h}$ and never recovered after $5 \mu \mathrm{M}$ acrolein treatment (Fig.13A-B), showing that acrolein can affect the angiogenic ability of endothelial cells. 
Figure 13

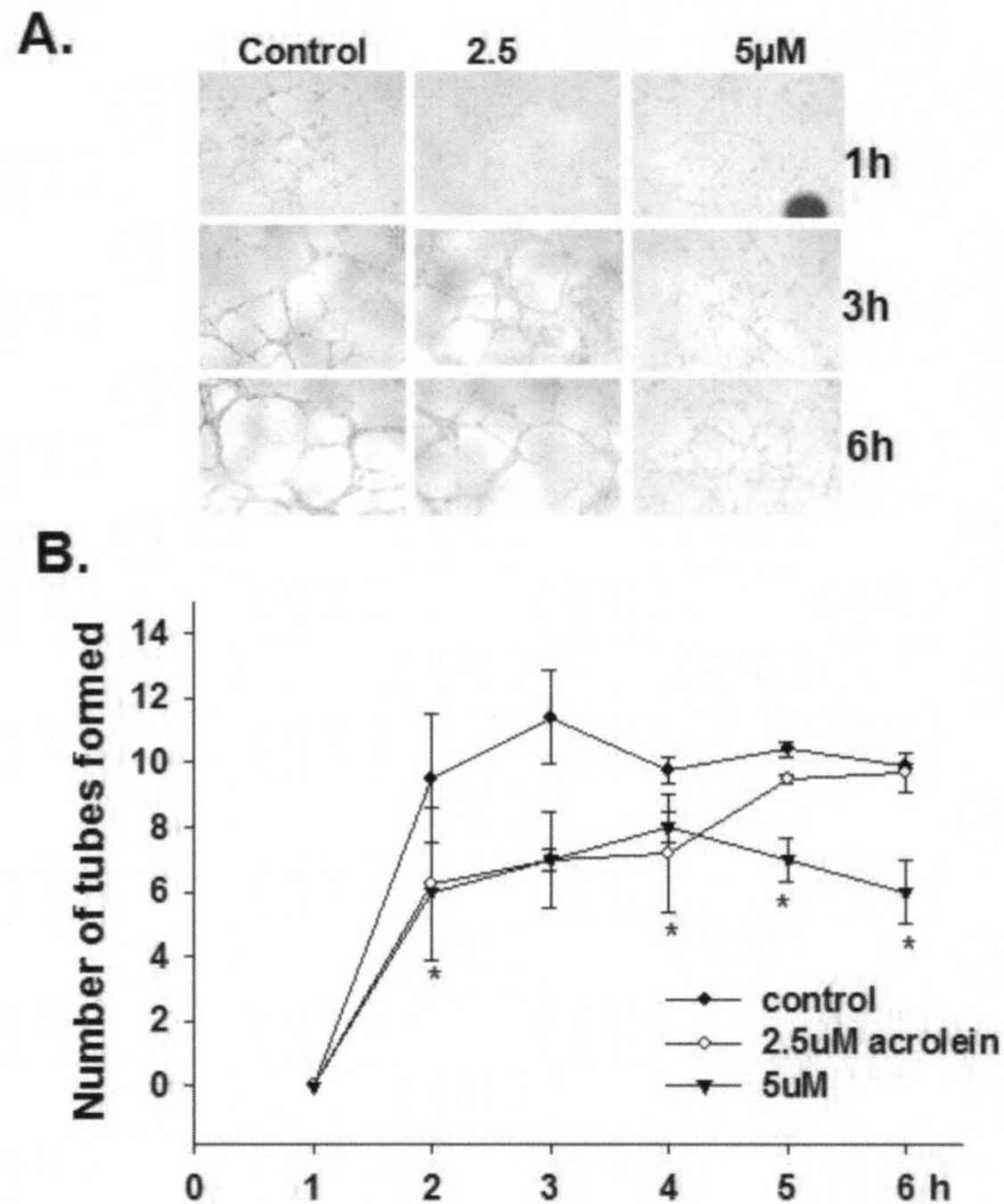


Figure 13. Model of in vitro angiogenesis. A, Representative images of in vitro tube formation after treatment with acrolein $0,2.5$, or $5 \mu \mathrm{M}$ for $30 \mathrm{~min}$. B, Quantification of tube formation following acrolein incubations. Data are mean $\pm \operatorname{SEM}(n=3 /$ group). * $p<0.05$ vs. control. 


\section{Ischemic injury recovery}

Ischemic injury has been shown to mobilize EPCs and play an intricate part in wound healing and neovascularization of injured tissue ${ }^{136}$. Our studies have shown that acrolein decreases circulating EPCs but increases proliferation within the bone marrow ${ }^{187}$. Any changes in mobilization of EPCs due to acrolein inhalation will be more apparent when EPC levels peak within the circulation after induction of $\mathrm{HLI}$. To determine peak EPC mobilization after ischemic injury, we performed a time course study. EPCs were measured in mice without $\mathrm{HLI}$, and at $2,4,8$, and $12(n=4)$ days after the induction of HLI. EPC levels in circulation peaked 2 days after hindlimb ischemia, then returned baseline levels by day 12 (Fig.14B). To determine the effect acrolein has on mobilization of EPCs in response to ischemic injury, mice were exposed to $1 \mathrm{ppm}$ acrolein inhalation 4 days pre-surgery and continued acrolein inhalation 2 days post-surgery (Scheme 7). Peripheral blood was drawn and flow cytometry analysis performed to determine circulating EPC levels. EPCs were gated as previously described, Flk$1^{+} /$Sca- $1^{+}$cells were gated out and plotted for CXCR4 positivity (Fig.14A). Acrolein did not affect circulating Sca- $1^{+} / \mathrm{CXCR} 4^{+}$cell number (Fig. 14C). However, acrolein did decrease Flk $-1^{+} / \mathrm{Sca}-1^{+} / \mathrm{CXCR} 4+$ cells within the circulation ( $n=6,6 ;$ air $4.7 \pm 0.8$ cells/ $\mu \mathrm{L} ;$ acrolein $2.9 \pm 1$ cells $/ \mu \mathrm{L} ; p<0.05 ; n=6,6 ;$ Fig. 14D). To determine whether EPCs are in an increased proliferative state within the bone marrow, we examined cell cycle of Flk- $1^{+} / \mathrm{Sca}-1^{+}$cells and found no difference between cell cycle or total cell numbers (Fig. 14E). Stem, T-and B-cells that mobilized were measured to determine if any subset of $\mathrm{Flk}-1^{+} / \mathrm{Sca}-1^{+} \mathrm{EPCs}$ were 
affected. A subset within the Flk $-1^{+} / \mathrm{Sca}-1^{+}$cell population, $\mathrm{CD} 31^{+} / \mathrm{B} 220 /^{+} \mathrm{CD} 8-$ $/ \mathrm{CD} 19^{+} / \mathrm{CD}^{+}$cells were increased in acrolein-exposed mice compared with air (air $0.05 \% \pm 0.005$; acrolein $0.08 \% \pm 0.005 ; p<0.05 ; n=6,6$; Fig. 14E-G). The stem cell panel showed that two different subsets of Flk+/Sca+ cells were decreased in acrolein-exposed mice compared with air; subset $1 \mathrm{~B} 220^{+} / \mathrm{CD} 31^{+} / \mathrm{CD} 11 \mathrm{~b}-$ ,CD115-/CD19 ${ }^{+}$(air 0.08 $\pm 0.002 \%$; acrolein $0.05 \pm 0.001 \% ; n=6,6 ; p<0.05 ; n=6,6$; Fig. 14H-I) subset 2 B220+/CD31+/CD11b-,CD115-/CD19- (air 0.09 \pm 0.001 ; acrolein $0.04 \pm 0.001 ; n=6 ; p<0.05 ; n=6,6$; Fig. 14H-I).

External wound healing and EPC response to ischemic injury is hampered in smokers but is reversible with cessation of smoking ${ }^{188}$. To further elucidate if acrolein had any effect on superficial wound healing like what is seen in smokers, double $5 \mathrm{~mm}$ punch wound technique was employed. A short 2 day punch model was used to test if acrolein inhalation affected mobilization of EPC in response to the injury (Scheme 7). Circulating EPC levels in the punch wound model was not significant between air-exposed and acrolein-exposed mice (Fig.15A-D). 
Scheme 7 Two day hindlimb ischemia treatment protocol

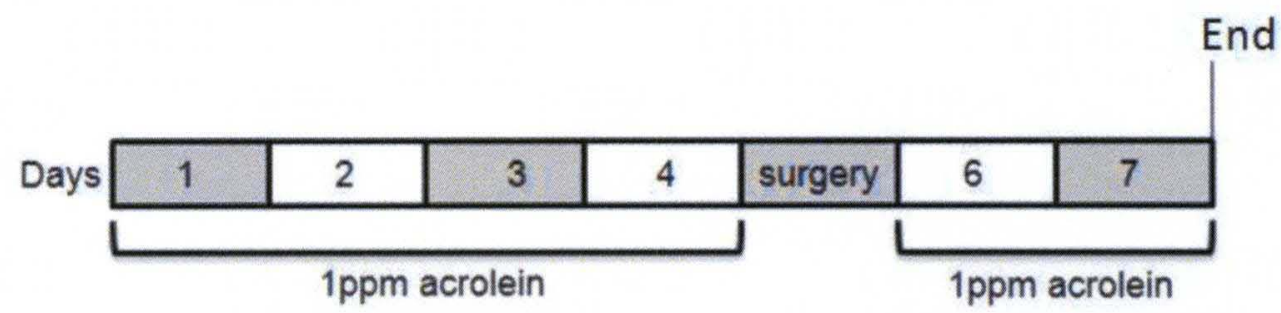


Figure 14

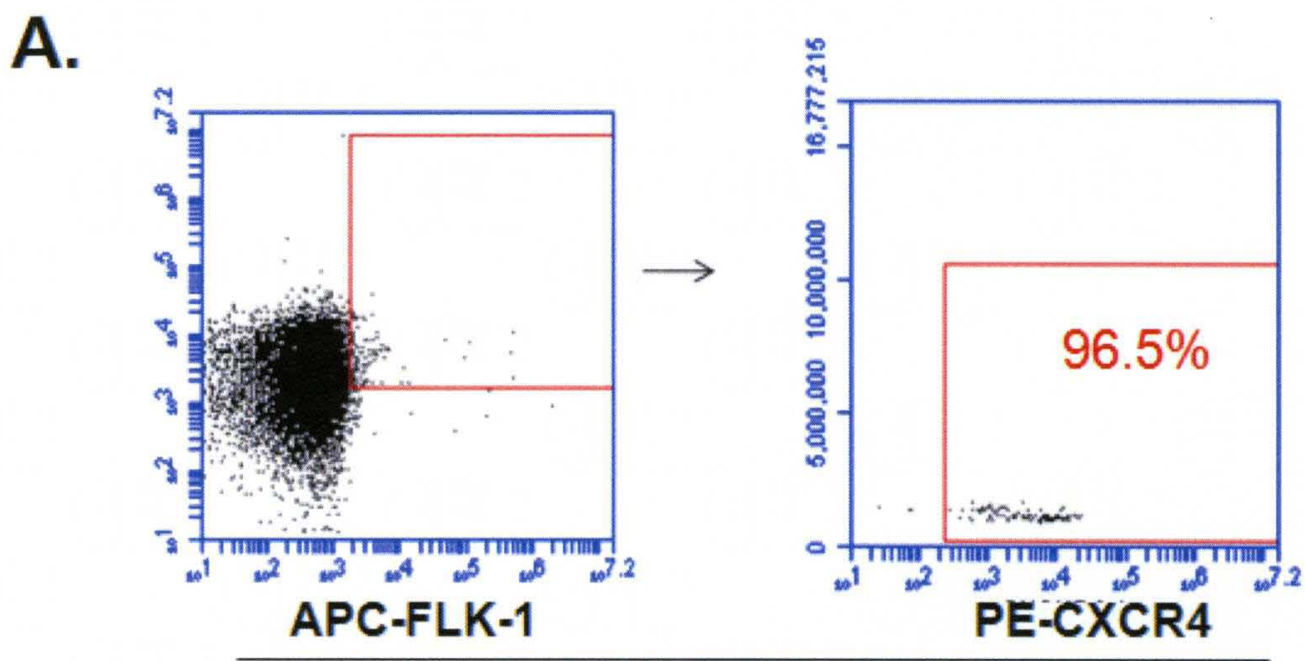

Air
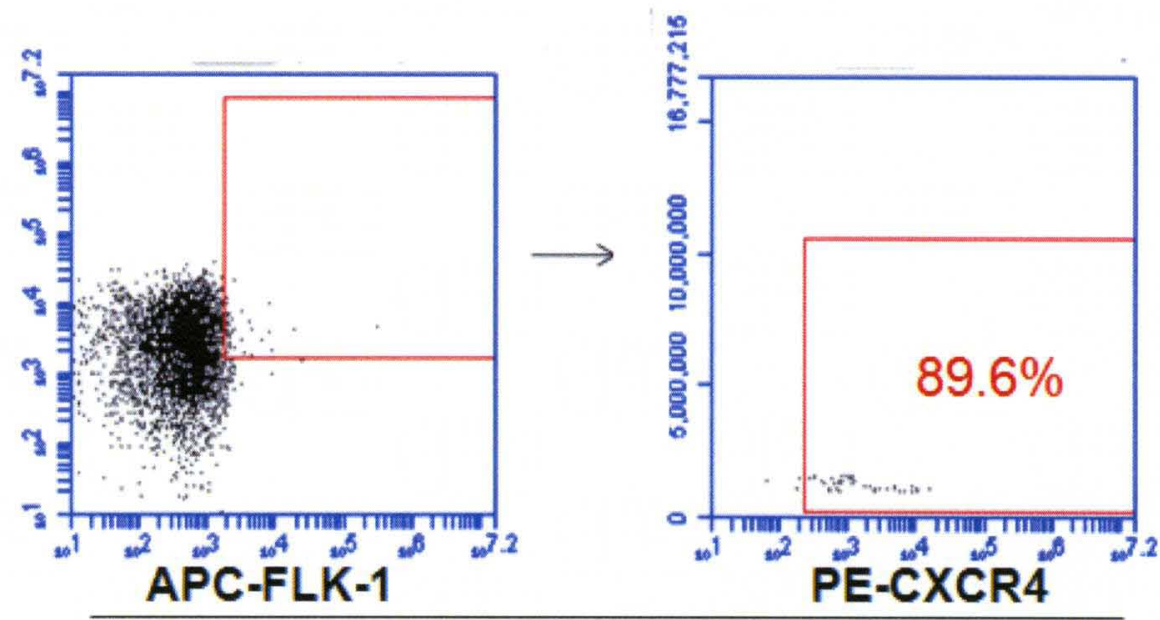

Acrolein 
B.
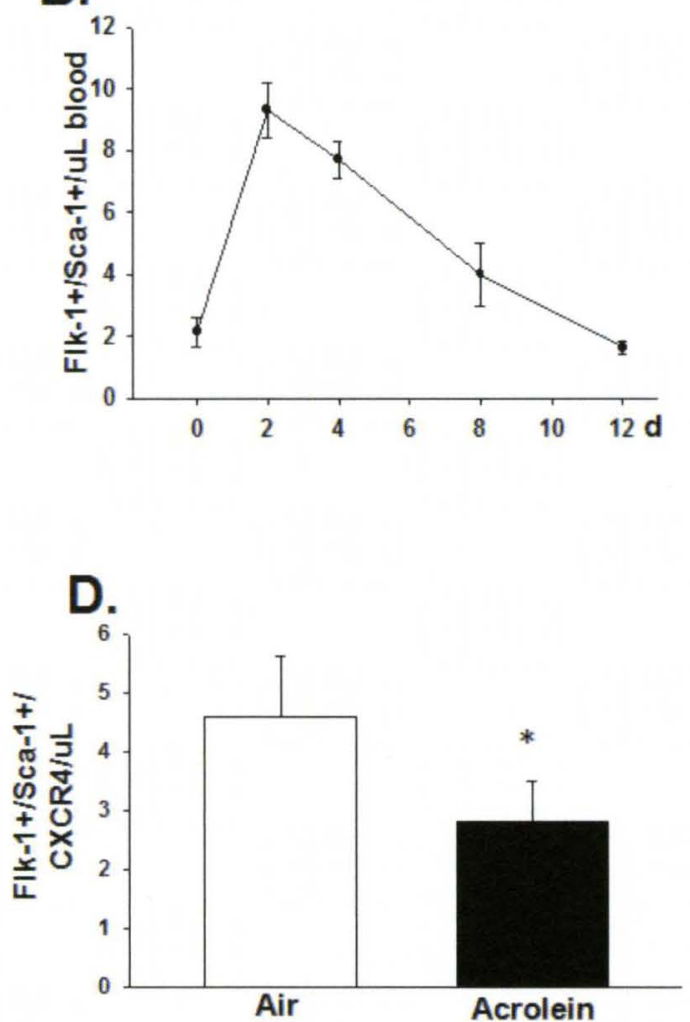

c.
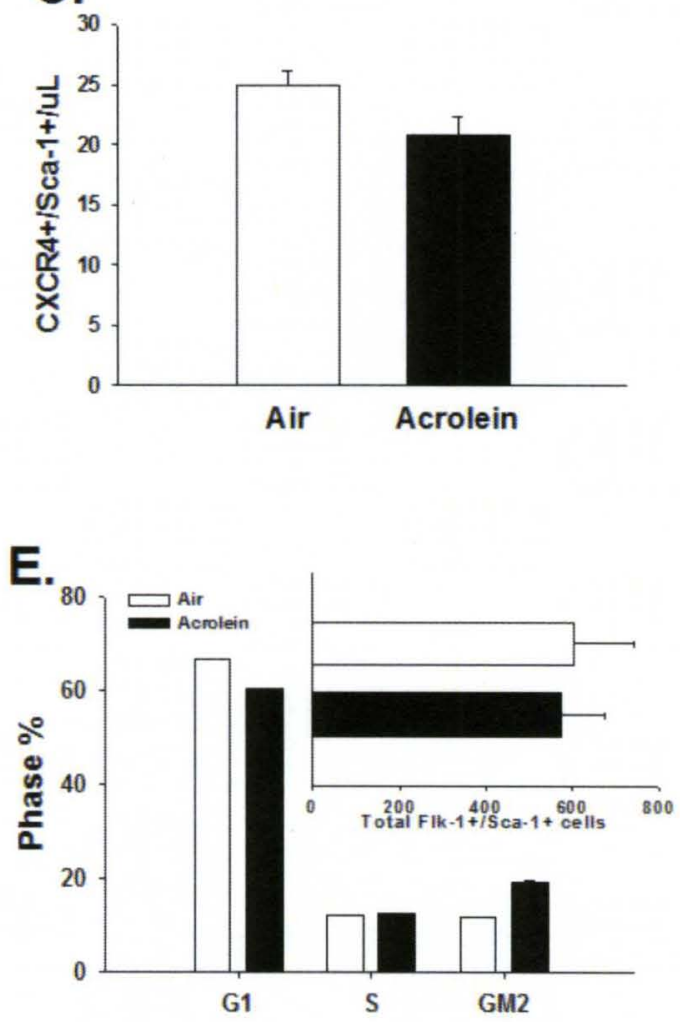
F.
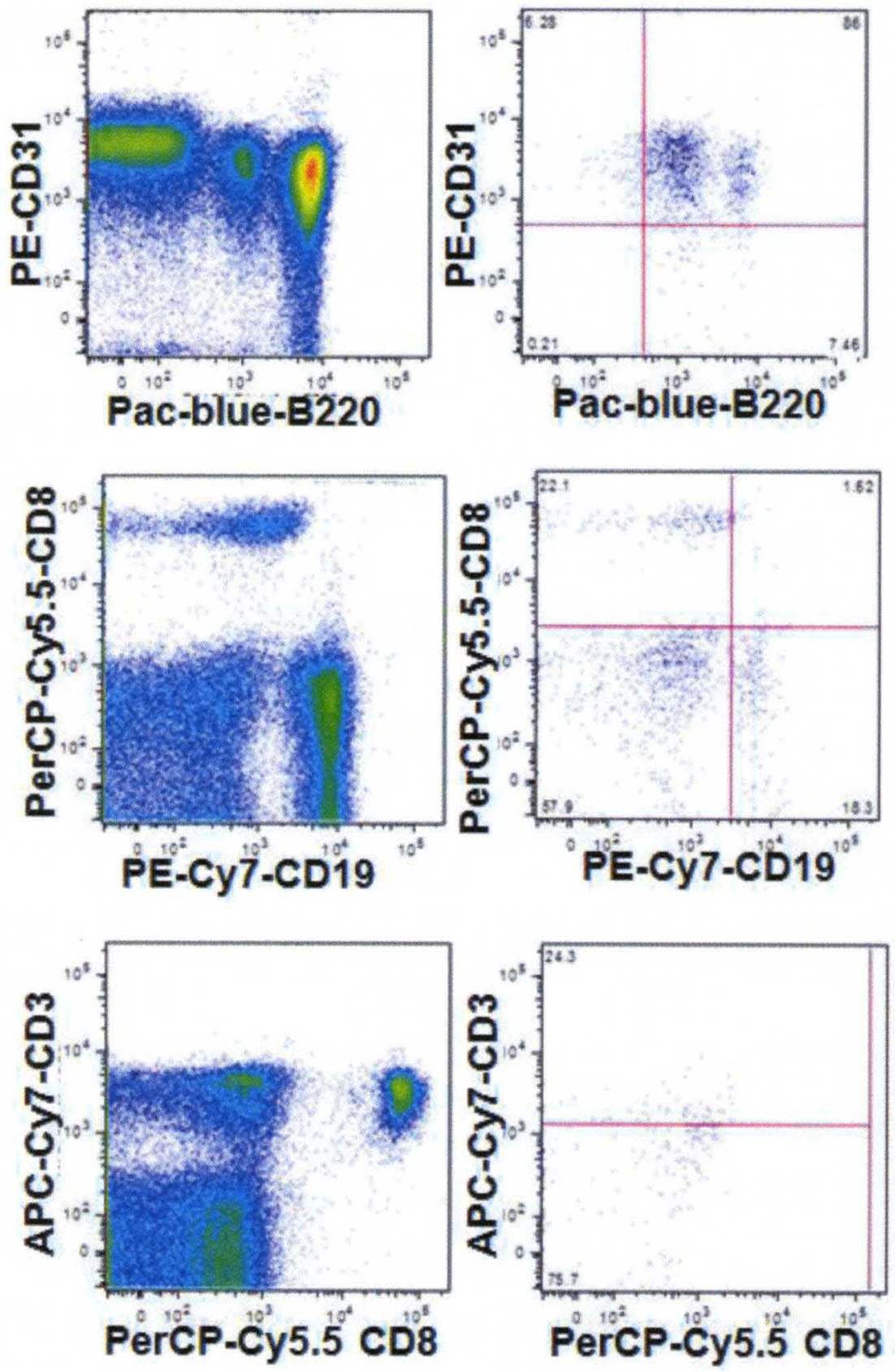


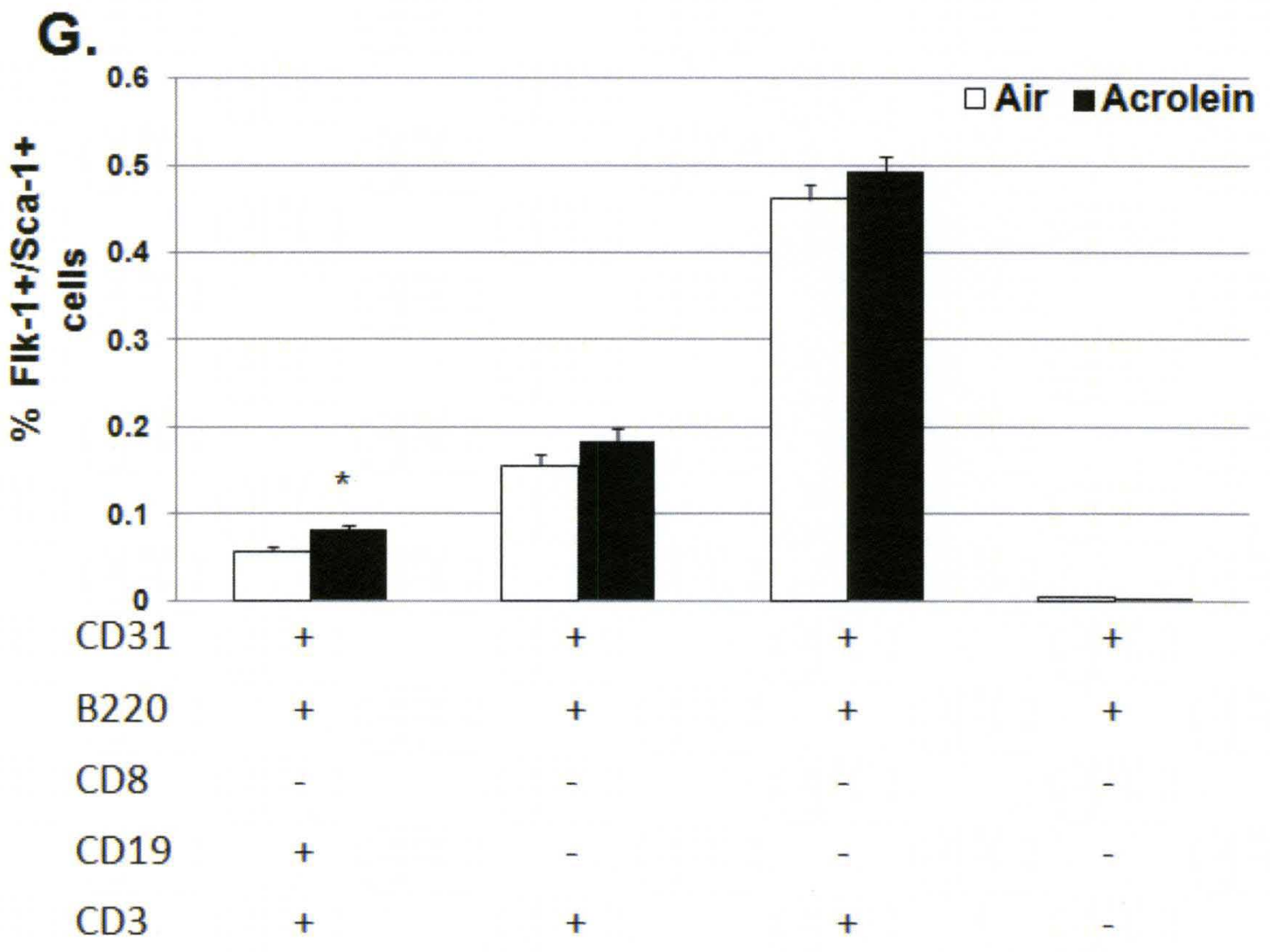


H.

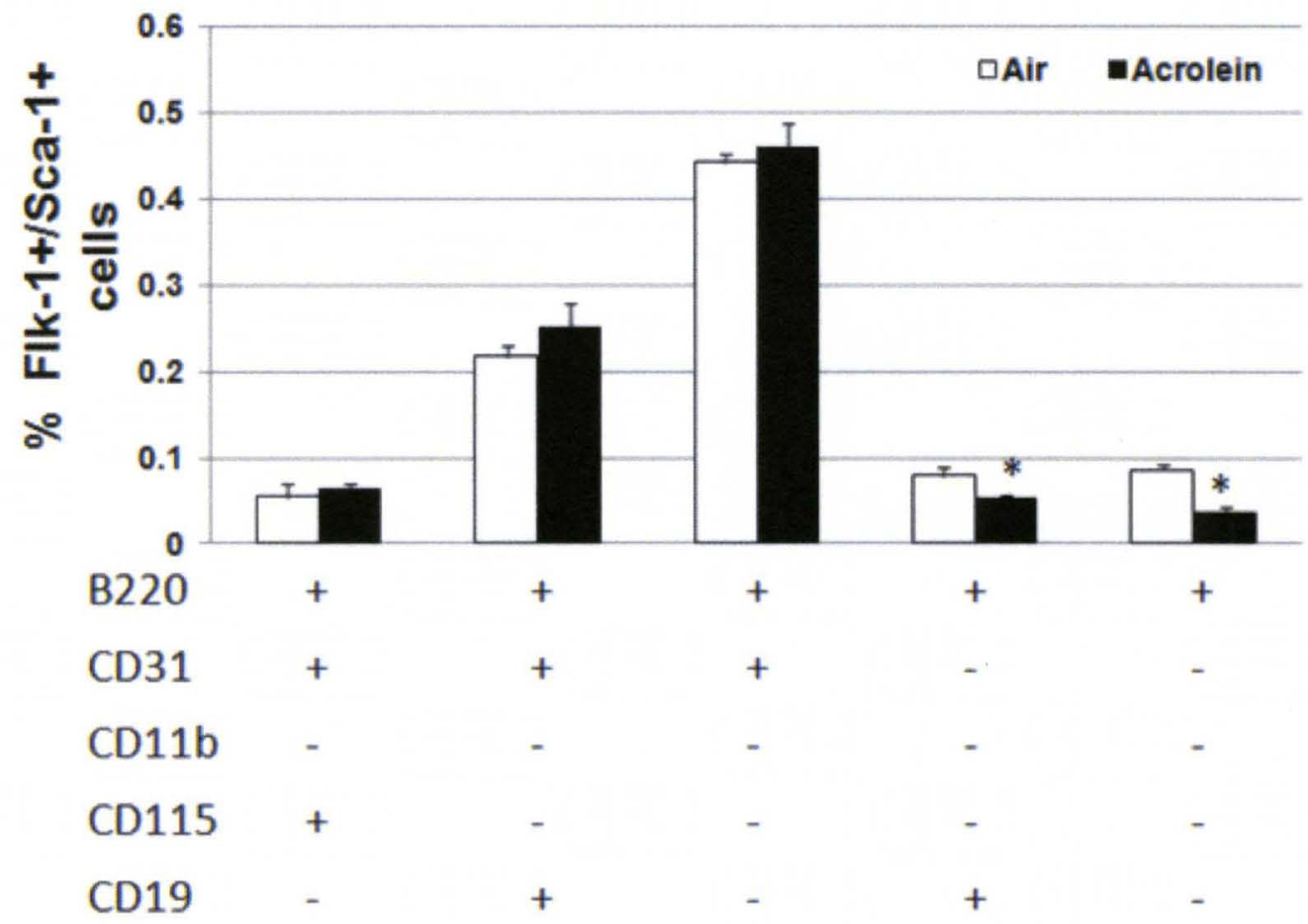


Figure 14. Two day mouse model of hindlimb ischemia and characterization and $A$, representative dot plots of gated FSC and PE-CXCR4 fluorescence of Flk $-1^{+} / \mathrm{Sca}-1^{+}$cells that are also CXCR4 positive from air- and acrolein- treated mice. B, Quantification of time course EPC levels per $\mu \mathrm{L}$ after the induction of hindlimb ischemia, measurements taken from baseline, days 2, 4, 8 and 12 from whole blood. C, Quantification of CXCR4 $4^{+} / \mathrm{Sca}-1^{+}$cells from 2 day hindlimb ischemia after $1 \mathrm{ppm}$ acrolein inhalation from whole peripherial blood. $\mathbf{D}$, Quantification of Flk $-1^{+} / \mathrm{Sca}-1^{+} / \mathrm{CXCR} 4^{+}$cells 2 days after hindlimb ischemia and $1 \mathrm{ppm}$ acrolein inhalation from whole blood. E, Quantification of cell cycle from bone marrow Flk- $1^{+} / \mathrm{Sca}-1^{+}$cells of 2 day $1 \mathrm{ppm}$ acrolein hindlimb ischemia mice. F, representative dot plots of gated FSC and gated T-cell and B-cell markers. G, Characterization of $\mathrm{Flk}-1^{+} / \mathrm{Sca}-1^{+}$cell using T and B-cell markers after 2 days of hindlimb ischemia and $1 \mathrm{ppm}$ acrolein exposure. $\mathbf{H}$, representative dot plots of gated FSC and Stem cell markers I, Characterization of $\mathrm{Flk}-1^{+} / \mathrm{Sca}-1^{+}$cell using stem cell markers after 2 days of hindlimb ischemia and $1 \mathrm{ppm}$ acrolein exposure. Data are mean \pm SEM ( $n=4-6 /$ group). * $p<0.05$ vs. control. 
In order to determine if acrolein could affect wound closure we examined the progression of wound healing. Double $5 \mathrm{~mm}$ punch wounds were induced dorsally and followed until $90 \%$ closure (Scheme 8 ). Wound closure of acroleinexposed mice was not significantly different when compared to air controls, in both groups there was $90 \%$ wound closure within 10 days (Fig.15E-G).

To further determine acroleins effect on ischemia induced EPC mobilization, a more severe model of hindlimb ischemia was employed. Mice were exposed to $1 \mathrm{ppm}$ acrolein for 4 days prior to HLI surgery. After surgery profusion recovery was followed and laser Doppler profusion images were taken of ischemic and non-ischemic limbs on days $0,8,12$, and 18 (Scheme 9). There was no significance between profusion recovery of acrolein-exposed mice when compared to air-exposed mice (Fig. 16A-B). Circulating EPC levels were compared on day 20 of $\mathrm{HLI}, \mathrm{Sca}-1^{+} / \mathrm{CXCR} 4^{+}$cells and $\mathrm{Flk}-1^{+} / \mathrm{Sca}-1^{+} / \mathrm{CXCR} 4^{+}$ cells were not significant when compared with air-exposed mice (Fig. 16C-D). For further confirmation and analysis of angiogenesis thigh and Gastronemius muscles of both ischemic and non-ischemic legs were harvested and stained for immunofluorescence. Tissue sections were stained for UE-Lectin to detect capillary density and $\alpha-s m o o t h$ muscle actin ( $\alpha-S M A)$ in order to detect arterioles (Fig. 16E). Quantification of capillary density and total number of a-SMA positive vessels showed there were no changes in angiogenesis after hindlimb ischemia between acrolein- and air-exposed mice (Fig. 16F-G). 
Scheme 8 Two day punch wound model treatment protocol

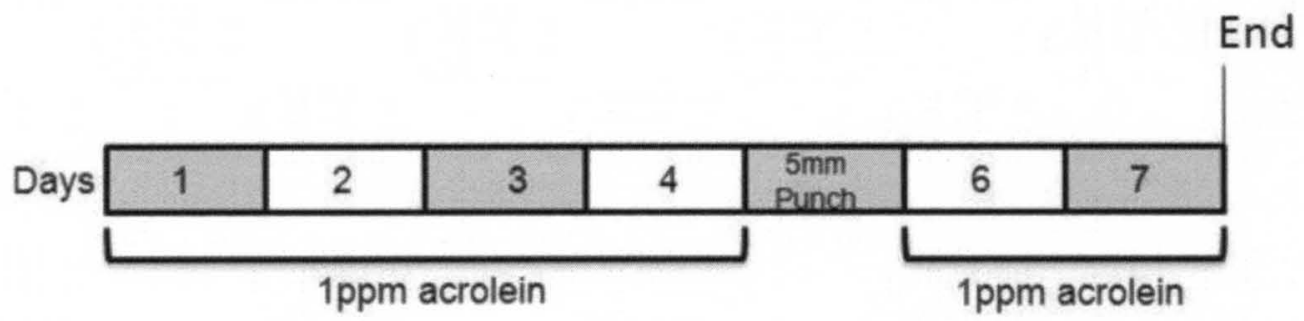

Scheme 9 Ten day punch wound treatment protocol

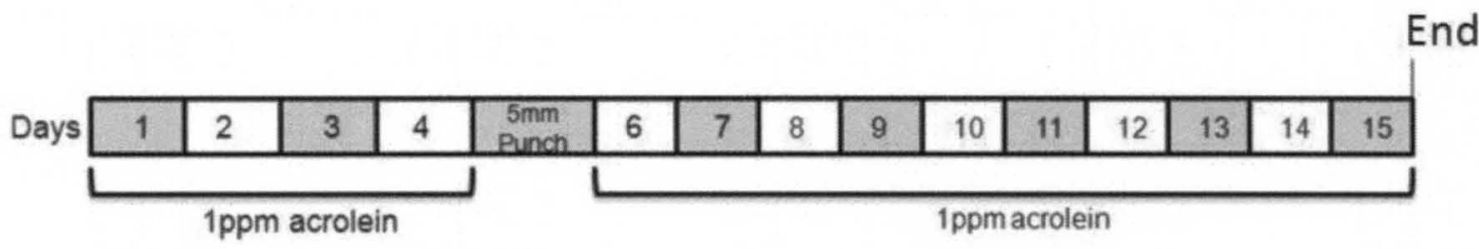


Figure 15
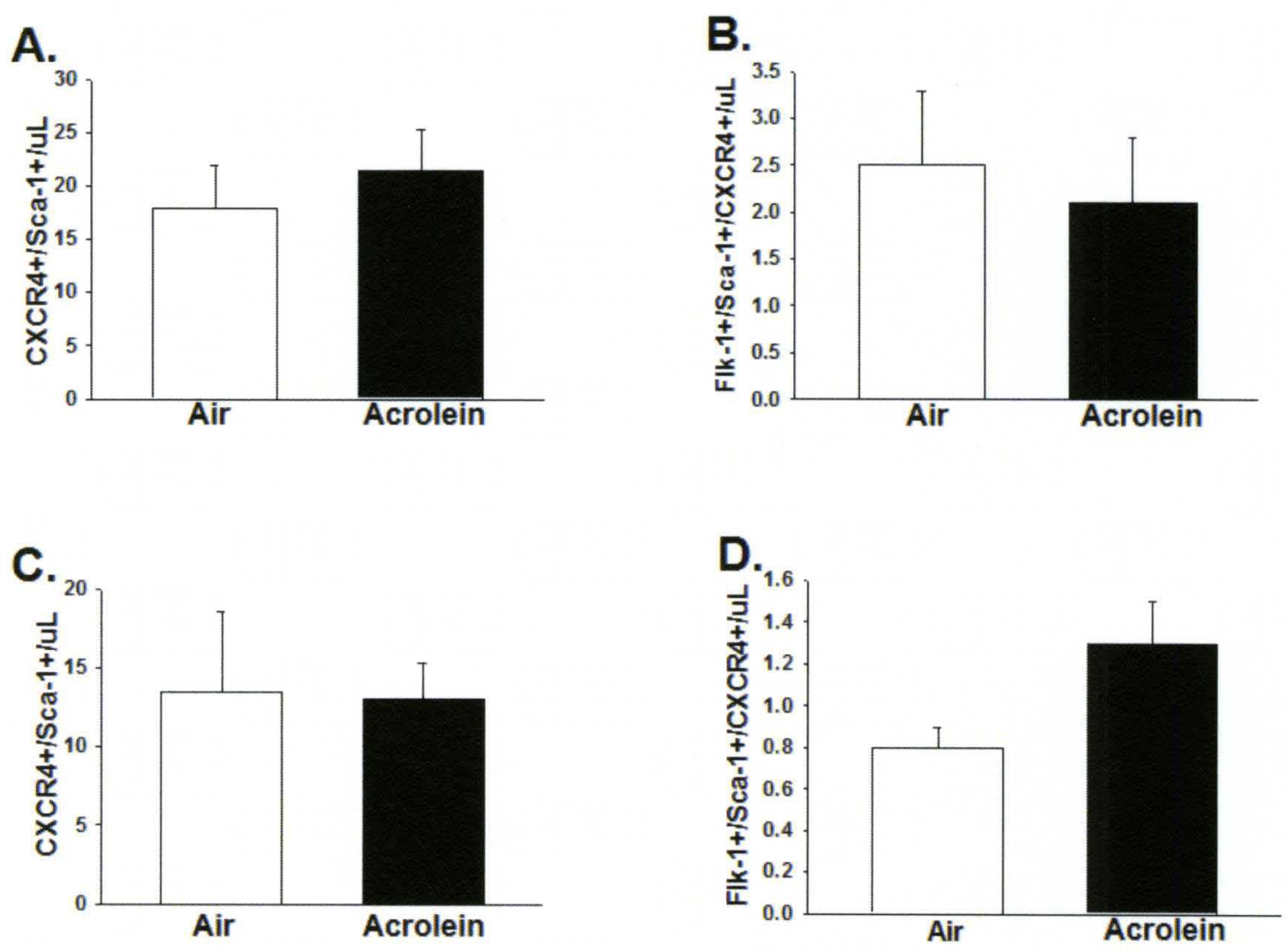

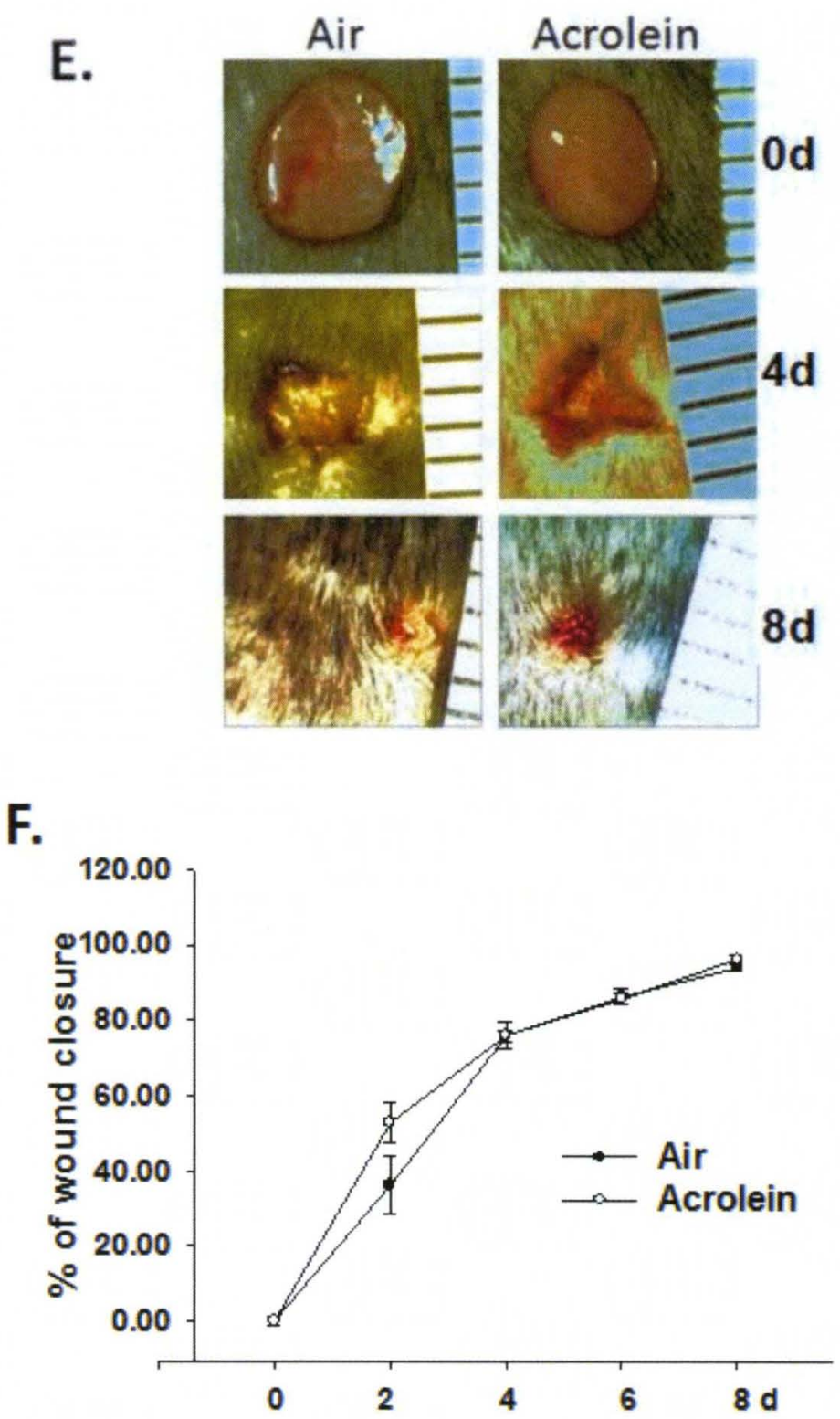
Figure 15. Punch wound mouse model. A, Quantification of CXCR4+/Sca-1+ cells from 2 day punch wound model after $1 \mathrm{ppm}$ acrolein inhalation from whole peripheral blood. B, Quantification of Flk-1+/Sca-1+/CXCR4 $4^{+}$cells after 2 days punch wound model after $1 \mathrm{ppm}$ acrolein inhalation from whole blood. $\mathbf{C}$, Quantification of $\mathrm{CXCR} 4^{+} / \mathrm{Sca}-1^{+}$cells from 10 day punch wound model after $1 \mathrm{ppm}$ acrolein inhalation from whole peripheral blood $\mathrm{D}$, Quantification of CXCR4 $4^{+} / \mathrm{Sca}-1^{+}$cells from 10 day punch wound model after $1 \mathrm{ppm}$ acrolein inhalation from whole peripheral blood $\mathbf{E}$, Representative images of $5 \mathrm{~mm}$ punch wound on day 0 and $8 \mathbf{F}$, Quantification of punch wound healing every 2 days until day 8. Data are mean $\pm S E M$ ( $n=6 /$ group). * $p<0.05$ vs. control. 
Scheme10 Twenty day hindlimb ischemia treatment protocol

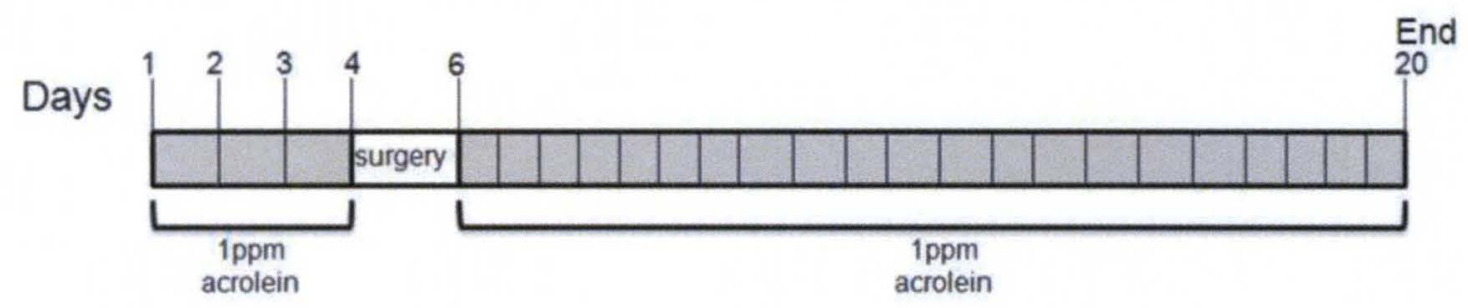


Figure 16

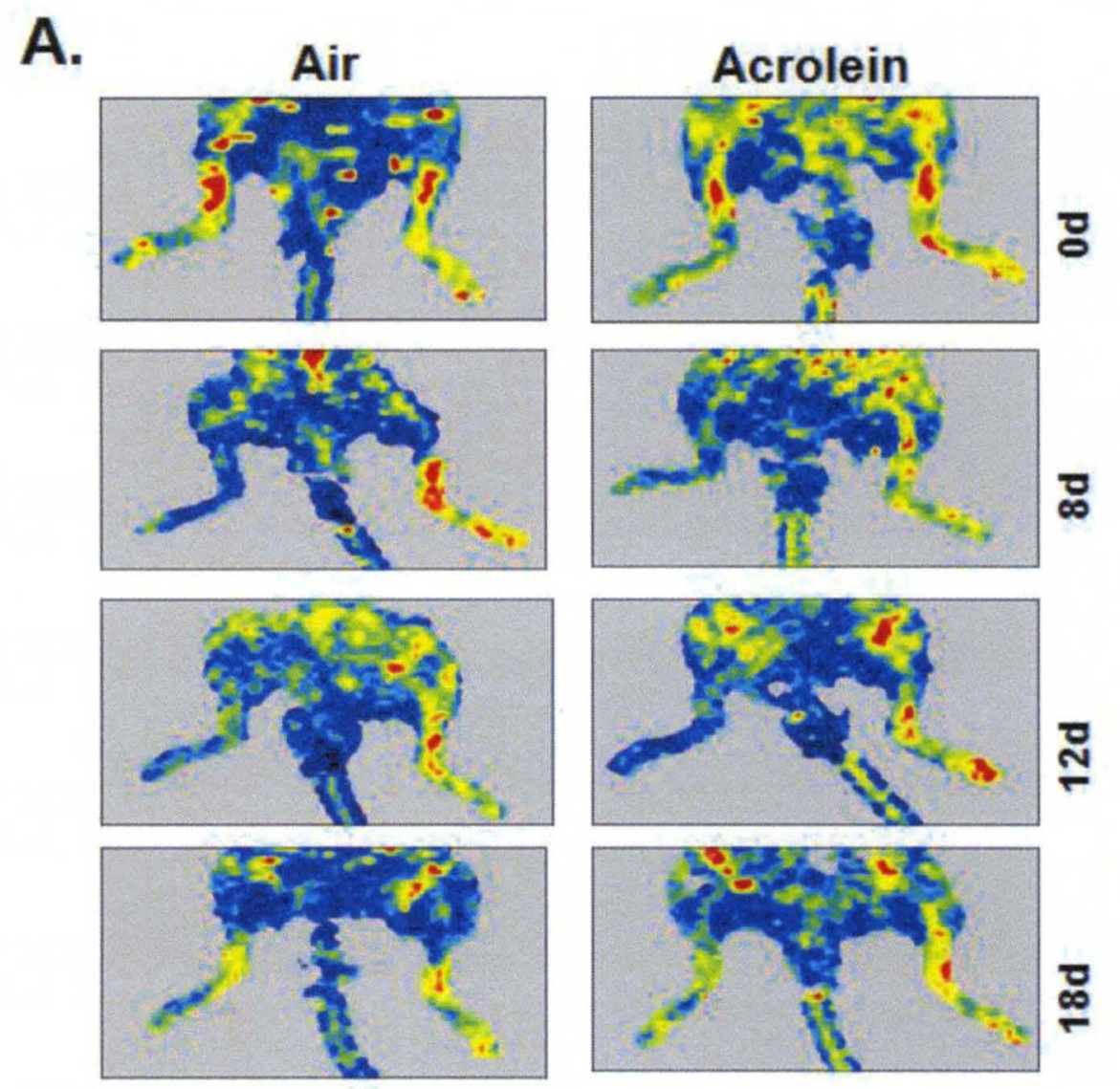


B.

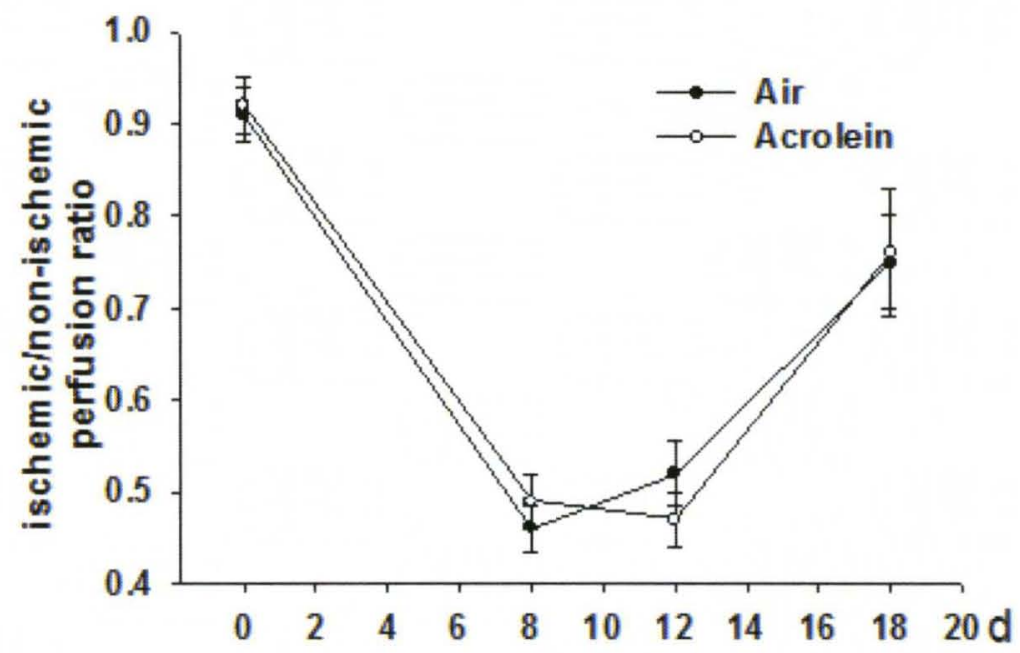

E.

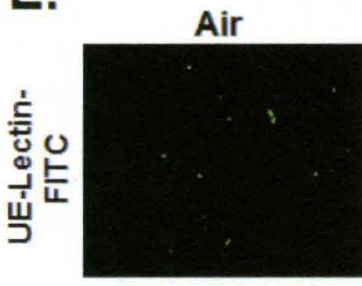

2

案
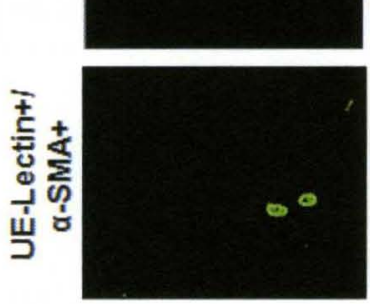

F.
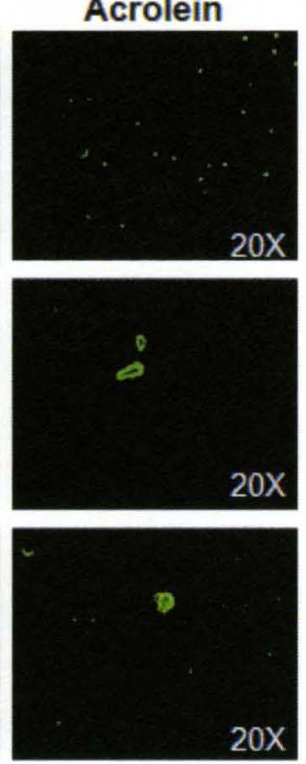

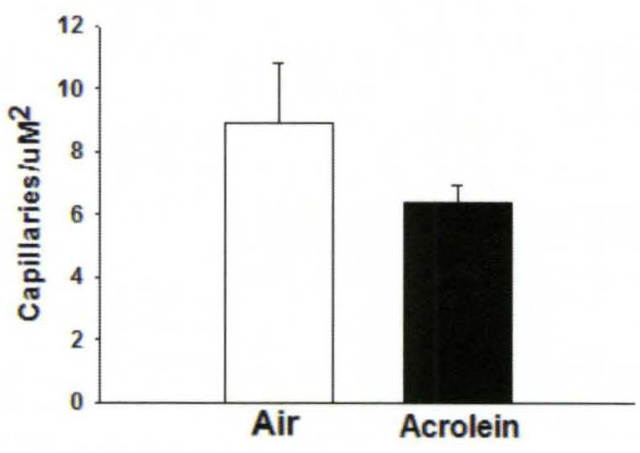

G.

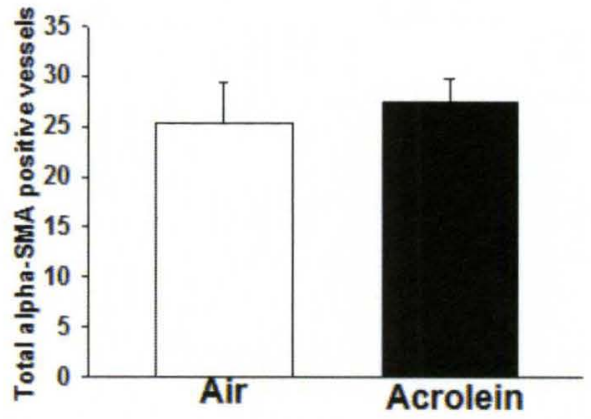


Figure 16. Hindlimb ischemia perfusion recovery and acrolein 1ppm inhalation. A, Representative laser Doppler measurements at days 0, 8, 12 and 18. B, Quantification of laser Doppler perfusion ratios following hindlimb ischemia in control mice, or mice exposed to $1 \mathrm{ppm}$ acrolein inhalation. C, Quantification of Sca+ cells from 20 day hindlimb ischemia model after $1 \mathrm{ppm}$ acrolein inhalation from whole peripheral blood D, Quantification of Flk-1+/Sca-1+ cells from 20 days of hindlimb ischemia and $1 \mathrm{ppm}$ acrolein inhalation from whole peripherial blood. E, Representative photographs of thigh muscle from 20 day hindlimb ischemia mice and 1ppm acrolein exposure, stained for UE-Lectin and arterioles. F, Quantification of capillary and, G, total $\alpha$-SMA positive vessels. Data are mean $\pm S E M\left(n=6 /\right.$ group). ${ }^{*} p<0.05$ vs. control. 
$\mathrm{HLI}$ perfusion was followed for an extended time to determine the affect acrolein potentially has on angiogenesis in vivo. Higher concentrations of acrolein $(2 \mathrm{ppm})$ were used to determine if the effect is dose dependant (Scheme 11). Acrolein mice did not have hampered leg reperfusion, both air- and acroleinexposed mice had $74-76 \%$ recovery of blood flow by day 10 post-surgery (Fig.17 A-B). Circulating Sca- $1^{+} / \mathrm{CXCR} 4^{+}$cells remained insignificant at this time point as well. Acrolein-exposed mice had significantly decreased levels of EPCs (Flk$1^{+} / \mathrm{Sca}-1^{+} / \mathrm{CXCR} 4^{+}$) compared with air-exposed mice (air 4.4 \pm 0.5 ; acrolein 1.4 $\pm 0.3 ; n=6,6 ; p<0.05$; Fig. 17 C-D). Complete blood counts of acrolein-exposed mice were decreased after induction of $\mathrm{HLI}$ in both $1 \mathrm{ppm} / 2 \mathrm{~d}$ acrolein inhalations and 2ppm/10d acrolein inhalations (Table 11). 
Scheme 11 Ten day hindlimb ischemia treatment protocol

Days \begin{tabular}{|l|l|l|l|l|l|l|l|l|l|l|l|l|l|l|}
\hline 1 & 2 & 3 & 4 & surgery & 6 & 7 & 8 & 9 & 10 & 11 & 12 & 13 & 14 & 15 \\
\hline
\end{tabular}


Figure 17

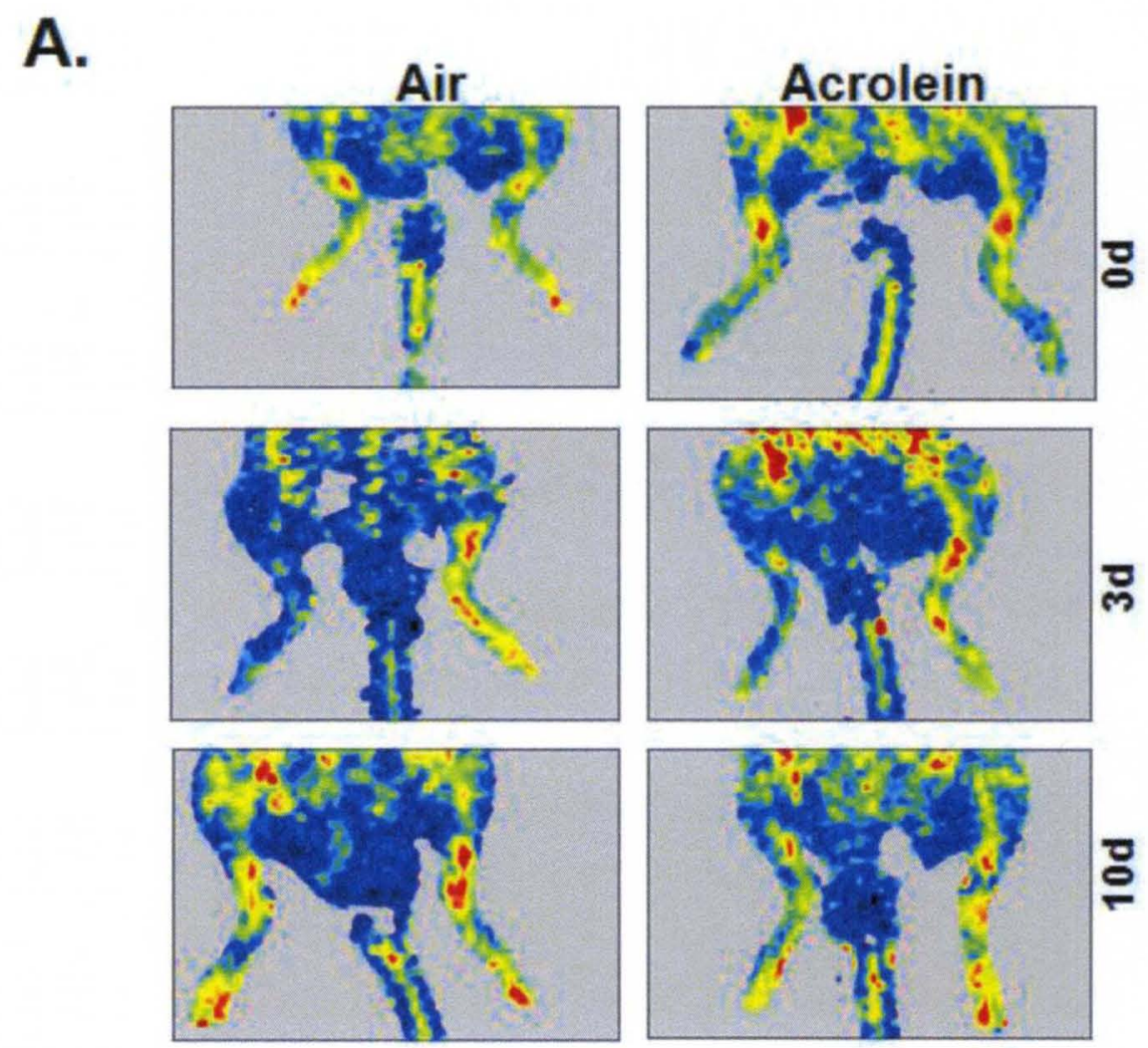


B.

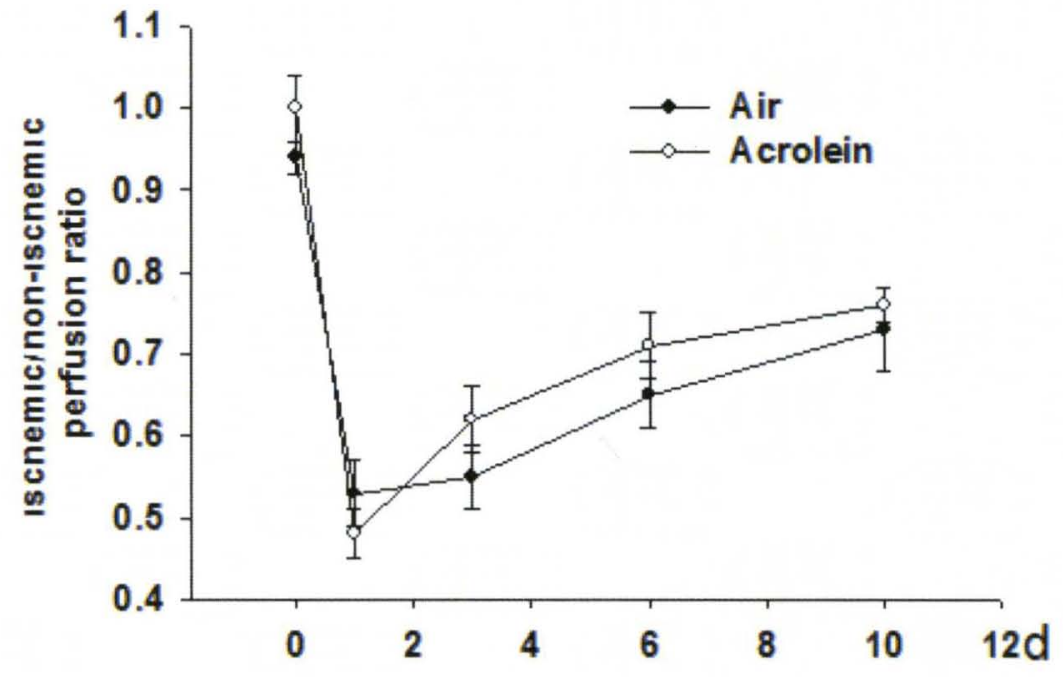

C.

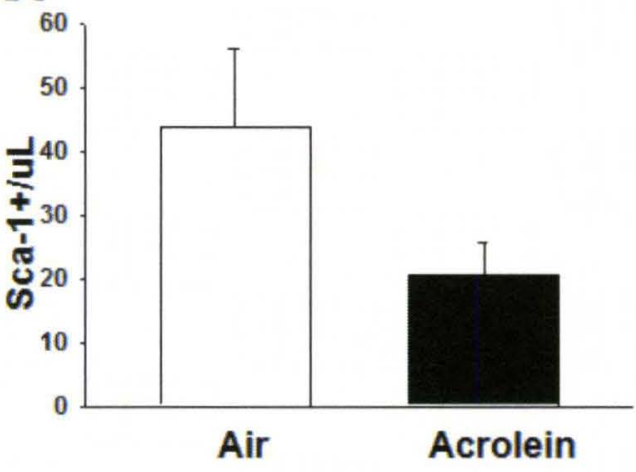

D.

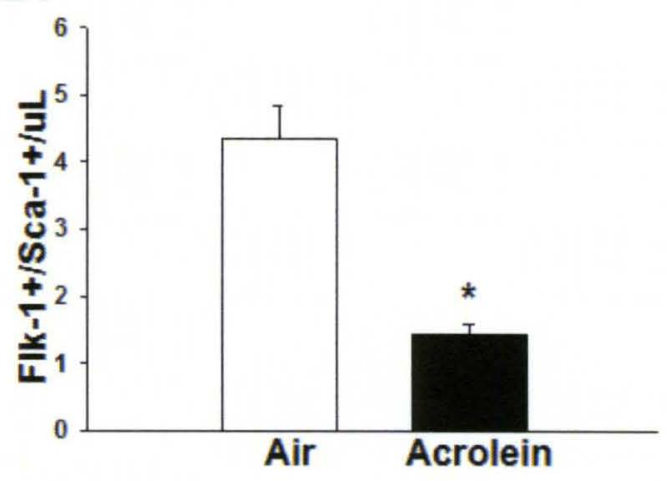


Figure 17. Hindlimb ischemia perfusion recovery of acrolein $2 \mathrm{ppm}$ inhalation mice. A, Representative laser Doppler measurements at days $0,1,3$, 6, 10. B, Quantification of laser Doppler perfusion ratios following hindlimb ischemia in control mice, or mice exposed to $2 \mathrm{ppm}$ acrolein inhalation. C, Quantification of Sca- $1^{+}$cells from 10 day hindlimb ischemia model after $2 \mathrm{ppm}$ acrolein inhalation from whole peripheral blood D, Quantification of Flk-1 ${ }^{+} / \mathrm{Sca}-1^{+}$ cells from 10 days of hindlimb ischemia and $2 \mathrm{ppm}$ acrolein inhalation from whole peripheral blood. 
Blood parameters in C57BL6 mice exposed to air or acrolein with $\mathrm{HLI}$

\begin{tabular}{|c|c|c|c|c|c|c|c|}
\hline & \multirow{2}{*}{$\begin{array}{c}\text { Control no HLI } \\
\text { Air }\end{array}$} & \multicolumn{2}{|c|}{$20 \mathrm{HLI}$} & \multicolumn{2}{|c|}{ 200HLI } & \multicolumn{2}{|c|}{ 100HLI } \\
\hline & & Air & Acrolein $1 \mathrm{ppm}$ & Air & Acrolein, 1ppm & Air & Acrolein, 2ppm \\
\hline WBC & $2370 \pm 585$ & $3832 \pm 399$ & $2173 \pm 178^{\circ}$ & $2100 \pm 320$ & $1663 \pm 172$ & $3363 \pm 376$ & $1676 \pm 334^{\circ}$ \\
\hline$N E^{s}$ & $362 \pm 64$ & $744 \pm 93$ & $400 \pm 34^{*}$ & $334+80$ & $183+23$ & $686 \pm 55$ & $313 \pm 42^{*}$ \\
\hline LY: & $1942 \pm 518$ & $2098 \pm 391$ & $1708 \pm 173^{+}$ & $1668 \pm 246$ & $1397 \pm 146$ & $2528 \pm 330$ & $1286 \pm 283^{\circ}$ \\
\hline MO: & $57 \pm 15$ & $82 \pm 17$ & $45 \pm 32^{*}$ & $74 \pm 17$ & $78 \pm 11$ & $141 \pm 24$ & $73 \pm 17^{\circ}$ \\
\hline $\mathrm{RBC}^{\mathrm{b}}$ & $9035 \pm 298$ & $7796 \pm 283$ & $7915 \pm 199$ & $7750 \pm 274$ & $7996 \pm 274$ & $8716 \pm 227$ & $8418+224$ \\
\hline HCT $(\%)$ & $42.2+1.2$ & $33.9 \pm 13$ & $34.3 \pm 0.9$ & $34.8 \pm 0.4$ & $35.9 \pm 11$ & $37.38 \pm 1.0$ & $36.5 \pm 11$ \\
\hline$H b c$ & $11.1 \pm 0.3$ & $114 \pm 0.5$ & $118 \pm 03$ & $116 \pm 0.2$ & $117 \pm 0.4$ & $12.15 \pm 0.3$ & $12.0 \pm 0.3$ \\
\hline PLT• & $835 \pm 50$ & $579 \pm 35$ & $509 \pm 25$ & $565 \pm 17$ & $569 \pm 21$ & $783 \pm 53$ & $652 \pm 32$ \\
\hline MCV & $46.9 \pm 0.3$ & $43.8 \pm 0.2$ & $43.7 \pm 0.2$ & $449 \pm 0.4$ & $44.8 \pm 0.3$ & $42.9 \pm 0.6$ & $43.4 \pm 0.2$ \\
\hline $\mathrm{MCH}=$ & $12.2 \pm 0.1$ & $14.7 \pm 0.2$ & $14.9 \pm 02$ & $14.9 \pm 02$ & $14.6 \pm 0.1$ & $13.9 \pm 0.2$ & $142 \pm 0.1$ \\
\hline $\mathrm{MCHC}^{\mathrm{c}}$ & $26.1 \pm 0.1$ & $33.4 \pm 0.3$ & $34.1 \pm 0.4$ & $33.2 \pm 0.2$ & $32.6 \pm 0.3$ & $32.5 \pm 0.3$ & $32.8 \pm 32.3$ \\
\hline RDW $(\%)$ & $17.3 \pm 0.5$ & $16.8 \pm 0.2$ & $16.1 \pm 0.3$ & $17.1 \pm 0.3$ & $17.0 \pm 0.2$ & $17.5 \pm 0.3$ & $17.3 \pm 0.2$ \\
\hline MPVa & $38+01$ & $41+0.03$ & $41+0.03$ & $40+003$ & $40+0.03$ & $4.3 \pm 0.06$ & $4.1 \pm 0.1$ \\
\hline
\end{tabular}

Male, 12-14 week old mice were exposed to air or acrolein ( 1 or 6 h/day) for 4 days, with or without HU, $n=6$ per group. Mice were

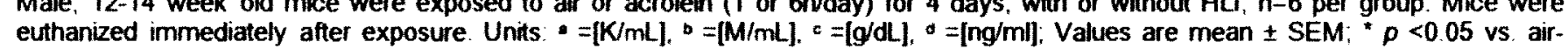
matched group; $n=8$ mice/group. Abbr: WBC, white blood cell; NE, neutrophil; LY, lymphocyte; MO, monocytes, RBC, red blood cell; $\mathrm{HCT}$, hematocrit; $\mathrm{Hb}$ hemoglobin; PLT, platelet, $\mathrm{MCV}$, mean corpuscular volume; $\mathbf{M C H}$ mean corpuscular hemoglobin; $\mathrm{MCHC}$, mean corpuscular hemoglobin concentration; RDW, red cell distribution width, MPV, mean platelet volume. p<0.05, One-Way ANOVA; compared to there prospective air groups 


\section{Discussion}

In the present study, we show that acrolein treatment decreases spontaneous tube formation of HUVECs in vitro and acrolein inhalation decreases mobilization of EPCs in response to ischemic injury.

Previous studies have shown that exposure to cigarette smoke decreases circulating EPCs and decreases angiogenic recovery after induction $\mathrm{HLI}^{189}$. Acrolein inhalations that were performed are pure exposures to acrolein, compared to the plethora of chemicals contained in cigarette smoke, so there cannot be a direct comparison between the results of these two studies. However, acrolein is a highly reactive component found within cigarette smoke and is a likely candidate for the development of vascular pathologies seen in smokers. Indeed, in this present study we report a decrease in tube formation by HUVECs treated with acrolein for $30 \mathrm{~min}$.

Angiogenesis and neovascularization are complex biologic responses and are important processes in ischemic injury and disease ${ }^{190}$. In both post-natal physiological and pathological neovascularization bone marrow-EPCs play an essential role ${ }^{191}$. Studies have shown HLI causes mobilization of EPCs from bone marrow to the site of ischemic injury, mobilization of EPCs is essential for

profusion recovery and limb salvage ${ }^{192}$. Ischemic injury is a strong stimulus for increased release of VEGF, which is a potent EPC mobilizer ${ }^{193}$. In an attempt to elucidate if acrolein affects mobilization of EPCs in response to ischemic injury, mice were exposed to $1 \mathrm{ppm}$ acrolein for 4 days before HLI surgery and euthanized at the peak of EPC mobilization 2 days post-surgery. Circulating 
EPCs were significantly decreased in acrolein-exposed mice, confirming a blunted response to ischemic stimuli. Previous data have shown acroleinexposed mice have a hampered mobilization to VEGF-injections. These results support the conclusion that EPCs are not responding to endogenous VEGF level increases that occur after ischemic injury and thus do not mobilize ${ }^{187}$. However, the precise mechanism responsible for this blunted response and mobilization remains to be elucidated.

Circulating EPC levels have been positively correlated to cardiovascular health and increased angiogenesis with improved ischemic recovery ${ }^{136}$. We further investigated the decrease of circulating EPC levels and if the decrease would affect ischemic recovery of HLI. Serial Doppler imaging showed perfusion recovery was not affected in any $\mathrm{HLI}$ model; at $1 \mathrm{ppm} 20$ day post-HLI nor the 2ppm 10 day post-HLI model.

In conclusion, acrolein does affect EPC mobilization in response to ischemic injury. However, angiogenesis and reperfusion does not seem to be affected by acrolein inhalations. Despite the negative results reported here, acrolein could still affect angiogenic recovery after induction of $\mathrm{HLI}$. The question remains open and further research and technique development is needed to determine the affect acrolein exposure has on angiogenesis and the mechanism(s) involved. 


\section{CHAPTER IV}

\section{CONCLUDING DISCUSSION}

Studies presented here were designed to develop an understanding of how acrolein, a byproduct of environmental pollutants, affects vascular health by altering the recruitment and mobilization of endothelial progenitor cells (EPCs). My thesis is that EPCs are sensitive targets for environmental insults, such as acrolein, thus increasing the risk of developing cardiovascular disease and endothelial dysfunction. Studies described here show that exposure to acrolein by inhalation (Aim 1), prevents mobilization of EPCs by cytokine stimulation (Aim 2). These studies also, evaluated perfusion recovery after hindlimb ischemia in mice exposed to acrolein inhalation (Aim 3).

Results of the first set of experiments (Chapter II), show that inhaled acrolein preferentially suppresses circulating endothelial progenitor cells (EPCs). Acrolein specifically decreases this cell population without affecting the level of Sca- $1^{+}$ cells, indicating a unique sensitivity of the EPC population to acrolein. The effects of acrolein on this population were, however, transient, and recovery in acroleinfree environment for 7 days led to a return of circulating EPCs to baseline levels. 
The decrease in circulating levels of EPCs appears to be the result of a defect in mobilization. Acrolein selectively suppressed basal levels of EPCs but not the Sca- $1^{+}$cell pool indicating that it preferentially affects VEGFR-2-expressing cells. In support of this conclusion, we found that acrolein exposure in vivo blocked VEGF-induced phosphorylation of Akt and eNOS in isolated aorta ex vivo. The prevention of EPC mobilization was also associated with decreased plasma $\mathrm{NO}_{\mathrm{x}}$ levels as well, suggesting that some of the effects of acrolein on EPC mobilization could be attributed in part to a decrease in NO production or bioavailablity.

We also found that acrolein inhalation was associated with the accumulation of protein-acrolein adducts in the plasma and bone marrow. This observation suggests that despite its high reactivity, acrolein is delivered from the lung into the systemic circulation and to distal vascular sites. Thus, acrolein appears to cross from the lungs and directly stimulate bone marrow EPCs. Indeed, our studies showed that bone marrow derived cells (BMDC) from acrolein-exposed mice were more proliferative when cultured on fibronectin-coated plates. Enhanced BMDC proliferation was observed as early as 1-2 days during initial colony formation, which contain clusters that stained for $\mathrm{Flk}-1^{+} / \mathrm{Sca}-1^{+}$as well as positive for acLDL uptake and Ulex lectin binding. The apparent increase in proliferation and a decrease in circulating EPC levels indicate that acrolein does not impair the growth or viability of these cells, but that it prevents their mobilization from the bone marrow. We suggest that this defect may be due to alterations in VEGF/ CXCR4 signaling but could also be related to other 
processes such as cell release from the bone marrow stroma. The specific mechanism by which acrolein enhances BMDC proliferation but inhibits their mobilization remains unknown and needs further investigation.

Because acrolein is one of the most reactive and toxic components of tobacco smoke, it is not surprising that many of the effects we observed with acrolein inhalation are consistent with tobacco smoke exposure. Our observations that acute high level acrolein slightly injures the murine endothelium are similar to reported effects of tobacco smoke on endothelial cells ${ }^{194}$. The acrolein-induced suppression of $\mathrm{NO}_{x}$ could be related to diminished levels of EPCs because both parameters returned to baseline levels following a 7-day recovery period. Moreover, we found that exposure to $1 \mathrm{ppm}$ acrolein for 4 days did not induce frank endothelial dysfunction although the levels of EPCs were decreased, suggesting that decreases in the circulating EPC levels precede endothelial dysfunction.

Humans are exposed to acrolein not only from tobacco smoke and air pollution, but also to acrolein present in foods and beverages ${ }^{165}$. In addition, acrolein is generated endogenously during lipid peroxidation and myeloperoxidase activity at sites of inflammation ${ }^{166}$. Our studies suggest that acrolein generated endogenously within the bone marrow or transported to the bone marrow from distal inflammatory processes could also suppress EPC mobilization and decrease circulating levels of EPCs by triggering mechanisms similar to those seen in animals exposed to inhaled acrolein. 
In this project, we characterized and counted EPCs independent of CD45 status because the majority (>90 \%) of EPCs express CD45 antigen. We reasoned that because of acrolein's propensity for targeting the endothelium, acrolein exposure could result in injury and mobilization of EPCs for repair. Chronic smoking is associated with a decrease in EPC levels in humans similar to the suppression of EPCs in blood that we have reported ${ }^{195}$. Hence, these finding suggest a novel connection between a specific component of cigarette smoke, acrolein, and air pollution generated from the combustion of organic materials and provide new insights into the mechanisms by which exposure to these pollutants can increase the risk of developing cardiovascular disease.

We next wanted to determine the effects acrolein had on vascular regeneration using in vivo and ex vivo approaches. Our cell culture studies showed that acrolein treatment decreased spontaneous tube formation of HUVECs seeding on Mitragel. To further elucidate the effects acrolein on angiogenesis and profusion recovery we studied two models of wound healing, i.e.,the punch model and hindlimb ischemia . However, we found that the progression of wound healing in these models was not affected by acrolein exposure-. We reasoned that the punch wound model is not a severe model of ischemia and does not elicit the hypoxic response necessary to significantly increase plasma VEGF and increase circulating EPC levels to the extent of HLI model ${ }^{196}$. Studies have shown VEGF exerts dominant functions during angiogenesis and is necessary for EPC mobilization from the bone marrow. Hindlimb ischemia is also a potent stimulator of VEGF release and mobilizes 
EPCs into the circulation almost 13 fold over baseline ${ }^{197}$. We found that with the induction of hindlimb ischemia, circulating EPC levels peak on day 2 of ischemic injury. However, after day 2 of HLI mice exposed to $1 \mathrm{ppm}$ acrolein had significantly decreased circulating EPC levels. This data suggests exposure to acrolein prevents EPC mobilization due to hindlimb ischemia perhaps by preventing the stimulatory effects of endogenous VEGF on the mobilization of EPCs from the bone marrow in response to HLI. To develop these observations further, an extended 1ppm acrolein exposure was carried out to determine if decreased circulating EPCs affected angiogenesis and reperfusion recovery after HLI . Our results showed that acrolein exposure did not affect circulating EPC levels or the rate of recovery of tissue perfusion. Hence, no determination could be made if EPCs affected perfusion recovery because EPC levels did not differ between control and inhalation animals. To examine whether the effects of acrolein on angiogenic recovery might be a dose-dependent phenomena, acrolein exposure levels were increased to $2 \mathrm{ppm}$. Our results with the higher dose showed a trend towards decreased perfusion recovery of $2 \mathrm{ppm}$ acroleinexposed mice, however this did not reach statistical significance. Circulating EPCs were also not significantly different in $\mathrm{HLI}$ of 2ppm acrolein-exposed mice when compared with air-exposed mice. Both 1ppm and 2ppm HLI studies produced negative results, however, in chapter III EPC levels were shown to return to baseline by day 12 of HLI. EPCs may become desensitized to mobilization stimuli after a period of time or EPCs mobilization could become exhausted after prolonged ischemic stimulation. Further research is needed to 
determine the possible detrimental effects that acrolein could have on angiogenesis, vascular repair and how this could potentially effect wound healing.

Overall, the data presented here support the global hypothesis that EPCs are a sensitive target for acrolein, thus increasing the risk for developing cardiovascular disease and endothelial dysfunction. 


\section{REFERENCES}

1. Quenel P, Zmirou D, Dab W, Le Tertre A, Medina S. Premature deaths and long-term mortality effects of air pollution. Int J Epidemiol. 1999;28:362

2. Rehfuess E, Corvalan C, Neira M. Indoor air pollution: 4000 deaths a day must no longer be ignored. Bull World Health Organ. 2006;84:508

3. Canada Centre for Remote Sensing., Instituto Nacional de Estadística Geografia e Informática (Mexico), Geological Survey (U.S.), Commission for Environmental Cooperation (Montréal Québec). North american environmental atlas, mapping our shared environment $=$ atlas environnemental de l'amérique du nord, cartographie d'un environnement nord-américain commun = atlas ambiental de américa del norte, cartografia de un medio ambiente compartido. 2010

4. Longo BM, Yang W, Green JB, Crosby FL, Crosby VL. Acute health effects associated with exposure to volcanic air pollution (vog) from increased activity at kilauea volcano in 2008. J Toxicol Environ Health A. 2010;73:1370-1381

5. Steerenberg PA, Dormans JA, van Doorn CC, Middendorp S, Vos JG, van Loveren $\mathrm{H}$. A pollen model in the rat for testing adjuvant activity of air pollution components. Inhal Toxicol. 1999;11:1109-1122 
6. Weinrich $M$, Vissiennon $T$, Kliche R, Schumann M, Bergmann A. [nature and frequency of the existence of mold fungi in garbage cans for biological waste and the resultant airborne spore pollution]. Berl Munch Tierarztl Wochenschr. 1999;112:454-458

7. Henderson SB, Brauer M, Macnab YC, Kennedy SM. Three measures of forest fire smoke exposure and their associations with respiratory and cardiovascular health outcomes in a population-based cohort. Environ Health Perspect. 2011

8. Howard EC, Henriksen JR, Buchan A, Reisch CR, Burgmann H, Welsh R, Ye W, Gonzalez JM, Mace K, Joye SB, Kiene RP, Whitman WB, Moran MA. Bacterial taxa that limit sulfur flux from the ocean. Science. $2006 ; 314: 649-652$

9. Stormer FC, Mysterud I. Cave smoke: Air pollution poisoning involved in neanderthal extinction? Med Hypotheses. 2007;68:723-724

10. Botello AV, Villanueva S, Diaz G. Petroleum pollution in the gulf of mexico and caribbean sea. Rev Environ Contam Toxicol. 1997;153:91-118

11. Conklin DJ, Haberzettl P, Prough RA, Bhatnagar A. Glutathione-stransferase $p$ protects against endothelial dysfunction induced by exposure to tobacco smoke. Am J Physiol Heart Circ Physiol. 2009;296:H1586-1597 
12. Ongley ED, Xiaolan Z, Tao Y. Current status of agricultural and rural nonpoint source pollution assessment in china. Environ Pollut. $2010 ; 158: 1159-1168$

13. Dwivedi AK, Tripathi BD. Pollution tolerance and distribution pattern of plants in surrounding area of coal-fired industries. J Environ Biol. 2007; $28: 257-263$

14. Standring WJ, Dowdall M, Amundsen I, Strand P. Floating nuclear power plants: Potential implications for radioactive pollution of the northern marine environment. Mar Pollut Bull. 2009;58:174-178

15. Leichter J. Decreased birth weight and attainment of postnatal catch-up growth in offspring of rats exposed to cigarette smoke during gestation. Growth Dev Aging. 1995;59:63-66

16. Kutlu T, Gelboin HV, Gozukara EM. Cigarette smoking and secondary smoke in turkey: Effect on placental aryl hydrocarbon hydroxylase (ahh), infant birth weight, and size. Bull Environ Contam Toxicol. 2002;69:855862

17. Hopkins JM, Evans HJ. Cigarette smoke-induced DNA damage and lung cancer risks. Nature. 1980;283:388-390

18. The long reach of cigarette smoke. New research extends the case against secondhand smoke by linking it to heart disease. Harv Heart Lett. 2004; $15: 6$ 
19. Prescott SL. Effects of early cigarette smoke exposure on early immune development and respiratory disease. Paediatr Respir Rev. 2008;9:3-9; quiz 10

20. Ibrahim AL, Zee YC, Osebold JW. The effects of ozone on the respiratory epithelium and alveolar macrophages of mice. I. Interferon production. Proc Soc Exp Biol Med. 1976;152:483-488

21. Thum T, Tsikas D, Stein S, Schultheiss M, Eigenthaler M, Anker SD, Poole-Wilson PA, Ertl G, Bauersachs J. Suppression of endothelial progenitor cells in human coronary artery disease by the endogenous nitric oxide synthase inhibitor asymmetric dimethylarginine. J Am Coll Cardiol. 2005;46:1693-1701

22. Saltzman BE, Svirbely JL. Ozone toxicity and substances associated with its production. AMA Arch Ind Health. 1957;15:111-118

23. Chen TM, Gokhale J, Shofer S, Kuschner WG. Outdoor air pollution: Nitrogen dioxide, sulfur dioxide, and carbon monoxide health effects. Am J Med Sci. 2007;333:249-256

24. Dashdendev B, Fukushima LK, Woo MS, Ganbaatar E, Warburton D. Carbon monoxide pollution and lung function in urban compared with rural mongolian children. Respirology. 2011;16:653-658

25. Aziz A, Bajwa IU. Minimizing human health effects of urban air pollution through quantification and control of motor vehicular carbon monoxide (co) in lahore. Environ Monit Assess. 2007;135:459-464 
26. Ziaei S, Nouri K, Kazemnejad A. Effects of carbon monoxide air pollution in pregnancy on neonatal nucleated red blood cells. Paediatr Perinat Epidemiol. 2005;19:27-30

27. Pershagen G, Rylander E, Norberg S, Eriksson M, Nordvall SL. Air pollution involving nitrogen dioxide exposure and wheezing bronchitis in children. Int J Epidemiol. 1995;24:1147-1153

28. Tewari A, Shukla NP. Air pollution--effects of nitrogen dioxide. Rev Environ Health. 1989;8:157-163

29. Stalker WW, Dickerson RC. Sampling station and time requirements for urban air pollution surveys. li. Suspended particulate matter and soiling index. J Air Pollut Control Assoc. 1962;12:111-128

30. Brook RD, Rajagopalan S, Pope CA, 3rd, Brook JR, Bhatnagar A, DiezRoux AV, Holguin F, Hong Y, Luepker RV, Mittleman MA, Peters A, Siscovick D, Smith SC, Jr., Whitsel L, Kaufman JD. Particulate matter air pollution and cardiovascular disease: An update to the scientific statement from the american heart association. Circulation. 2010;121:2331-2378

31. O'Toole TE, Hellmann J, Wheat L, Haberzettl P, Lee J, Conklin DJ, Bhatnagar A, Pope CA, 3rd. Episodic exposure to fine particulate air pollution decreases circulating levels of endothelial progenitor cells. Circ Res. 2010;107:200-203

32. Train RE. Sulfur dioxide pollution. Science. 1975;189:748-750

33. Sunyer J, Ballester F, Tertre AL, Atkinson R, Ayres JG, Forastiere F, Forsberg B, Vonk JM, Bisanti L, Tenias JM, Medina S, Schwartz J, 
Katsouyanni K. The association of daily sulfur dioxide air pollution levels with hospital admissions for cardiovascular diseases in europe (the aphea-ii study). Eur Heart J. 2003;24:752-760

34. Kan H, Wong CM, Vichit-Vadakan N, Qian Z. Short-term association between sulfur dioxide and daily mortality: The public health and air pollution in asia (papa) study. Environ Res. 2010;110:258-264

35. Environmental pollution. Biological monitoring of human exposure to environmental lead. Wkly Epidemiol Rec. 1992;67:265-268

36. Terzi R, Catenacci G, Marcaletti G, Maugeri U. [decrease in environmental pollution and changes in biological indicators in occupational exposure to lead]. Boll Soc Ital Biol Sper. 1984;60:1211-1216

37. Lin S, Wang X, Yu IT, Tang W, Miao J, Li J, Wu S, Lin X. Environmental lead pollution and elevated blood lead levels among children in a rural area of china. Am J Public Health. 2011;101:834-841

38. Nemery B, Hoet PH, Nemmar A. The meuse valley fog of 1930: An air pollution disaster. Lancet. 2001;357:704-708

39. Mills CA. The denora episode. Science. 1950;111:67

40. Davis DL, Bell ML, Fletcher T. A look back at the london smog of 1952 and the half century since. Environ Health Perspect. 2002;110:A734-735

41. Hunt A, Abraham JL, Judson B, Berry CL. Toxicologic and epidemiologic clues from the characterization of the 1952 london smog fine particulate matter in archival autopsy lung tissues. Environ Health Perspect. $2003 ; 111: 1209-1214$ 
42. Gillette R. Environmental protection agency: Chaos or "creative tension"? Science. 1971;173:703-707

43. Firestone M, Kavlock R, Zenick H, Kramer M. The u.S. Environmental protection agency strategic plan for evaluating the toxicity of chemicals. $J$ Toxicol Environ Health B Crit Rev. 2010;13:139-162

44. Athe atlas of population, environment and sustainable development of china $=$ [zhong hua ren min gong he guo ren kou huan jing yu ke chi xu fa zhan di tu ji]. Beijing: Science Press; 2000.

45. Wong CM, Atkinson RW, Anderson HR, Hedley AJ, Ma S, Chau PY, Lam TH. A tale of two cities: Effects of air pollution on hospital admissions in hong kong and london compared. Environ Health Perspect. 2002;110:6777

46. Wong TW, Yu TS, Tam W. Research on air pollution and health in hong kong. Asia Pac J Public Health. 2000;12 Suppl:S45-47

47. Kunzli N, Jerrett M, Mack WJ, Beckerman B, LaBree L, Gilliland F, Thomas D, Peters J, Hodis HN. Ambient air pollution and atherosclerosis in los angeles. Environ Health Perspect. 2005;113:201-206

48. Jerrett M, Burnett RT, Ma R, Pope CA, 3rd, Krewski D, Newbold KB, Thurston G, Shi Y, Finkelstein N, Calle EE, Thun MJ. Spatial analysis of air pollution and mortality in los angeles. Epidemiology. 2005;16:727-736

49. Krewski D, Burnett RT, Goldberg MS, Hoover K, Siemiatycki J, Abrahamowicz $\mathrm{M}$, White $\mathrm{WH}$. Validation of the harvard six cities study of particulate air pollution and mortality. N Engl J Med. 2004;350:198-199 
50. Krewski D, Burnett RT, Goldberg M, Hoover K, Siemiatycki J, Abrahamowicz M, Villeneuve PJ, White W. Reanalysis of the harvard six cities study, part ii: Sensitivity analysis. Inhal Toxicol. 2005;17:343-353

51. Gairola CG, Wu H, Gupta RC, Diana JN. Mainstream and sidestream cigarette smoke-induced DNA adducts in $\mathrm{c} 7 \mathrm{bl}$ and dba mice. Environ Health Perspect. 1993;99:253-255

52. Brunnemann KD, Kagan MR, Cox JE, Hoffmann D. Analysis of 1,3butadiene and other selected gas-phase components in cigarette mainstream and sidestream smoke by gas chromatography-mass selective detection. Carcinogenesis. 1990;11:1863-1868

53. O'Connor RJ, Hammond D, McNeill A, King B, Kozlowski LT, Giovino GA, Cummings KM. How do different cigarette design features influence the standard tar yields of popular cigarette brands sold in different countries? Tob Control. 2008;17 Suppl 1:11-5

54. Kazi TG, Jalbani N, Arain MB, Jamali MK, Afridi HI, Shah AQ.

Determination of toxic elements in different brands of cigarette by atomic absorption spectrometry using ultrasonic assisted acid digestion. Environ Monit Assess. 2009;154:155-167

55. Hoffmann D, Sanghvi LD, Wynder EL. Comparative chemical analysis of indian bidi and american cigarette smoke. Int J Cancer. 1974;14:49-53

56. Rabinoff M, Caskey N, Rissling A, Park C. Pharmacological and chemical effects of cigarette additives. Am J Public Health. 2007;97:1981-1991 
57. Borgerding MF, Bodnar JA, Chung HL, Mangan PP, Morrison CC, Risner $\mathrm{CH}$, Rogers JC, Simmons DF, Uhrig MS, Wendelboe FN, Wingate DE, Winkler LS. Chemical and biological studies of a new cigarette that primarily heats tobacco. Part 1. Chemical composition of mainstream smoke. Food Chem Toxicol. 1998;36:169-182

58. Schramm S, Carre V, Scheffler JL, Aubriet F. Analysis of mainstream and sidestream cigarette smoke particulate matter by laser desorption mass spectrometry. Anal Chem. 2011;83:133-142

59. Huxley RR, Woodward M. Cigarette smoking as a risk factor for coronary heart disease in women compared with men: A systematic review and meta-analysis of prospective cohort studies. Lancet. 2011;378:1297-1305

60. Jefferis BJ, Lawlor DA, Ebrahim S, Wannamethee SG, Feyerabend C, Doig M, McMeekin L, Cook DG, Whincup PH. Cotinine-assessed secondhand smoke exposure and risk of cardiovascular disease in older adults. Heart. 2010;96:854-859

61. Precioso J, Samorinha C, Calheiros JM, Macedo M, Antunes H, Campos $\mathrm{H}$. Second hand smoke (shs) exposure in children. An evaluation of a preventative measure. Rev Port Pneumol. 2010;16:57-72

62. Sanner $\mathrm{T}$. [the number of fatalities allegedly caused by smoking is being reduced]. Tidsskr Nor Laegeforen. 2005;125:3313 
63. McCall MR, van den Berg JJ, Kuypers FA, Tribble DL, Krauss RM, Knoff LJ, Forte TM. Modification of Icat activity and hdl structure. New links between cigarette smoke and coronary heart disease risk. Arterioscler Thromb. 1994;14:248-253

64. Edirisinghe I, Yang SR, Yao H, Rajendrasozhan S, Caito S, Adenuga D, Wong C, Rahman A, Phipps RP, Jin ZG, Rahman I. Vegfr-2 inhibition augments cigarette smoke-induced oxidative stress and inflammatory responses leading to endothelial dysfunction. FASEB J. 2008;22:22972310

65. Gusev MI, Svechnikova AI, Dronov IS, Grebenskova MD, Golovina AI. [on substantiation of the daily average maximum permissible concentration of acrolein in the atmosphere]. Gig Sanit. 1966;31:9-13

66. Faroon O, Roney N, Taylor J, Ashizawa A, Lumpkin MH, Plewak DJ. Acrolein environmental levels and potential for human exposure. Toxicol Ind Health. 2008;24:543-564

67. Stevens JF, Maier CS. Acrolein: Sources, metabolism, and biomolecular interactions relevant to human health and disease. Mol Nutr Food Res. $2008 ; 52: 7-25$

68. Stevens JF, Maier CS. Acrolein: Sources, metabolism, and biomolecular interactions relevant to human health and disease. Mol Nutr Food Res. $2008 ; 52: 7-25$ 
69. Uchida K, Kanematsu M, Morimitsu Y, Osawa T, Noguchi N, Niki E. Acrolein is a product of lipid peroxidation reaction. Formation of free acrolein and its conjugate with lysine residues in oxidized low density lipoproteins. J Biol Chem. 1998;273:16058-16066

70. Uchida K. Current status of acrolein as a lipid peroxidation product. Trends Cardiovasc Med. 1999;9:109-113

71. Mitchell DY, Petersen DR. Metabolism of the glutathione-acrolein adduct, s-(2-aldehydo-ethyl)glutathione, by rat liver alcohol and aldehyde dehydrogenase. J Pharmacol Exp Ther. 1989;251:193-198

72. Sharp DE, Berge MA, Paust DE, Talaat RE, Wilkes LC, Servatius LJ, Loftus ML, Caravello HE, Parent RA. Metabolism and distribution of [2,3(14)c]acrolein in lactating goats. J Agric Food Chem. 2001;49:1630-1638

73. Weber-Tschopp A, Fischer T, Grandjean E. [irritating effects of formaldehyde on man (author's transI)]. Int Arch Occup Environ Health. $1977 ; 39: 207-218$

74. Sim VM, Pattle RE. Effect of possible smog irritants on human subjects. $J$ Am Med Assoc. 1957;165:1908-1913

75. Lyon JP, Jenkins LJ, Jr., Jones RA, Coon RA, Siegel J. Repeated and continuous exposure of laboratory animals to acrolein. Toxicol Appl Pharmacol. 1970;17:726-732

76. Beauchamp RO, Jr., Andjelkovich DA, Kligerman AD, Morgan KT, Heck HD. A critical review of the literature on acrolein toxicity. Crit Rev Toxicol. $1985 ; 14: 309-380$ 
77. Park YS, Taniguchi N. Acrolein induces inflammatory response underlying endothelial dysfunction: A risk factor for atherosclerosis. Ann N Y Acad Sci. $2008 ; 1126: 185-189$

78. Asahara T, Murohara T, Sullivan A, Silver M, van der Zee R, Li T, Witzenbichler B, Schatteman G, Isner JM. Isolation of putative progenitor endothelial cells for angiogenesis. Science. 1997;275:964-967

79. Tilling $L$, Chowienczyk $P$, Clapp B. Progenitors in motion: Mechanisms of mobilization of endothelial progenitor cells. Br J Clin Pharmacol. 2009;68:484-492

80. Aicher A, Heeschen C, Mildner-Rihm C, Urbich C, Ihling C, Technau-Ihling K, Zeiher AM, Dimmeler S. Essential role of endothelial nitric oxide synthase for mobilization of stem and progenitor cells. Nat Med. 2003;9:1370-1376

81. Urbich C, Dimmeler S. Endothelial progenitor cells: Characterization and role in vascular biology. Circ Res. 2004;95:343-353

82. Wheat LA, Haberzettl P, Hellmann J, Baba SP, Bertke M, Lee J, McCracken J, O'Toole TE, Bhatnagar A, Conklin DJ. Acrolein inhalation prevents vascular endothelial growth factor-induced mobilization of flk1+/sca-1+ cells in mice. Arterioscler Thromb Vasc Biol. 2011;31:15981606

83. Rafii S, Lyden D. Therapeutic stem and progenitor cell transplantation for organ vascularization and regeneration. Nat Med. 2003;9:702-712 
84. Aicher A, Zeiher AM, Dimmeler S. Mobilizing endothelial progenitor cells. Hypertension. 2005;45:321-325

85. Kawamoto A, Asahara T. Role of progenitor endothelial cells in cardiovascular disease and upcoming therapies. Catheter Cardiovasc Inter. $2007 ; 70: 477-484$

86. Steinmetz M, Nickenig G, Werner N. Endothelial-regenerating cells: An expanding universe. Hypertension. 2010;55:593-599

87. Liu ZJ, Velazquez OC. Hyperoxia, endothelial progenitor cell mobilization, and diabetic wound healing. Antioxid Redox Signal. 2008;10:1869-1882

88. Ratajczak MZ, Kim CH, Abdel-Latif A, Schneider G, Kucia M, Morris AJ, Laughlin MJ, Ratajczak J. A novel perspective on stem cell homing and mobilization: Review on bioactive lipids as potent chemoattractants and cationic peptides as underappreciated modulators of responsiveness to sdf-1 gradients. Leukemia. 2011

89. Dar A, Schajnovitz A, Lapid K, Kalinkovich A, Itkin T, Ludin A, Kao WM, Battista M, Tesio M, Kollet O, Cohen NN, Margalit R, Buss EC, Baleux F, Oishi S, Fujii N, Larochelle A, Dunbar CE, Broxmeyer HE, Frenette PS, Lapidot T. Rapid mobilization of hematopoietic progenitors by amd3100 and catecholamines is mediated by cxcr4-dependent sdf- 1 release from bone marrow stromal cells. Leukemia. 2011;25:1286-1296 
90. Yamaguchi J, Kusano KF, Masuo O, Kawamoto A, Silver M, Murasawa S, Bosch-Marce M, Masuda H, Losordo DW, Isner JM, Asahara T. Stromal cell-derived factor-1 effects on ex vivo expanded endothelial progenitor cell recruitment for ischemic neovascularization. Circulation. $2003 ; 107: 1322-1328$

91. Chavakis $\mathrm{E}$, Urbich $\mathrm{C}$, Dimmeler S. Homing and engraftment of progenitor cells: A prerequisite for cell therapy. J Mol Cell Cardiol. 2008;45:514-522

92. Ceradini DJ, Kulkarni AR, Callaghan MJ, Tepper OM, Bastidas N, Kleinman ME, Capla JM, Galiano RD, Levine JP, Gurtner GC. Progenitor cell trafficking is regulated by hypoxic gradients through hif- 1 induction of sdf-1. Nat Med. 2004;10:858-864

93. Vajkoczy P, Blum S, Lamparter M, Mailhammer R, Erber R, Engelhardt B, Vestweber D, Hatzopoulos AK. Multistep nature of microvascular recruitment of ex vivo-expanded embryonic endothelial progenitor cells during tumor angiogenesis. J Exp Med. 2003;197:1755-1765

94. Walter DH, Haendeler J, Reinhold J, Rochwalsky U, Seeger F, Honold J, Hoffmann J, Urbich C, Lehmann R, Arenzana-Seisdesdos F, Aicher A, Heeschen C, Fichtlscherer S, Zeiher AM, Dimmeler S. Impaired cxcr4 signaling contributes to the reduced neovascularization capacity of endothelial progenitor cells from patients with coronary artery disease. Circ Res. 2005;97:1142-1151 
95. Chavakis E, Aicher A, Heeschen C, Sasaki K, Kaiser R, El Makhfi N, Urbich C, Peters T, Scharffetter-Kochanek K, Zeiher AM, Chavakis T, Dimmeler S. Role of beta2-integrins for homing and neovascularization capacity of endothelial progenitor cells. J Exp Med. 2005;201:63-72

96. Oh IY, Yoon CH, Hur J, Kim JH, Kim TY, Lee CS, Park KW, Chae IH, Oh $\mathrm{BH}$, Park YB, Kim HS. Involvement of e-selectin in recruitment of endothelial progenitor cells and angiogenesis in ischemic muscle. Blood. $2007 ; 110: 3891-3899$

97. Nishiwaki $Y$, Yoshida M, Iwaguro $H$, Masuda $H$, Nitta N, Asahara T, Isobe M. Endothelial e-selectin potentiates neovascularization via endothelial progenitor cell-dependent and -independent mechanisms. Arterioscler Thromb Vasc Biol. 2007;27:512-518

98. Biancone L, Cantaluppi V, Duo D, Deregibus MC, Torre C, Camussi G. Role of I-selectin in the vascular homing of peripheral blood-derived endothelial progenitor cells. J Immunol. 2004;173:5268-5274

99. Papayannopoulou T, Priestley GV, Nakamoto B, Zafiropoulos V, Scott LM. Molecular pathways in bone marrow homing: Dominant role of alpha(4)beta(1) over beta(2)-integrins and selectins. Blood. 2001;98:24032411

100. Chavakis E, Aicher A, Heeschen C, Sasaki K, Kaiser R, El Makhfi N, Urbich C, Peters T, Scharffetter-Kochanek K, Zeiher AM, Chavakis T, Dimmeler S. Role of beta2-integrins for homing and neovascularization capacity of endothelial progenitor cells. J Exp Med. 2005;201:63-72 
101. Nishiwaki $Y$, Yoshida M, Iwaguro H, Masuda H, Nitta N, Asahara T, Isobe M. Endothelial e-selectin potentiates neovascularization via endothelial progenitor cell-dependent and -independent mechanisms. Arterioscler Thromb Vasc Biol. 2007;27:512-518

102. Bahlmann FH, DeGroot K, Duckert T, Niemczyk E, Bahlmann E, Boehm SM, Haller $H$, Fliser $D$. Endothelial progenitor cell proliferation and differentiation is regulated by erythropoietin. Kidney Int. 2003;64:16481652

103. Hur J, Yoon CH, Lee CS, Kim TY, Oh IY, Park KW, Kim JH, Lee HS, Kang HJ, Chae IH, On BH, Park YB, Kim HS. Akt is a key modulator of endothelial progenitor cell trafficking in ischemic muscle. Stem Cells. $2007 ; 25: 1769-1778$

104. Gross $\mathrm{P}$, Herbrig K. Role of endothelial progenitor cells in cardiovascular pathology. Rocz Akad Med Bialymst. 2004;49:174-177

105. Asahara T, Kawamoto A. Endothelial progenitor cells for postnatal vasculogenesis. Am J Physiol Cell Physiol. 2004;287:C572-579

106. Goldstein LJ, Gallagher KA, Bauer SM, Bauer RJ, Baireddy V, Liu ZJ, Buerk DG, Thom SR, Velazquez OC. Endothelial progenitor cell release into circulation is triggered by hyperoxia-induced increases in bone marrow nitric oxide. Stem Cells. 2006;24:2309-2318 
107. De Falco E, Porcelli D, Torella AR, Straino S, lachininoto MG, Orlandi A, Truffa S, Biglioli P, Napolitano M, Capogrossi MC, Pesce M. Sdf-1 involvement in endothelial phenotype and ischemia-induced recruitment of bone marrow progenitor cells. Blood. 2004;104:3472-3482

108. Ackah E, Yu J, Zoellner S, Iwakiri Y, Skurk C, Shibata R, Ouchi N, Easton RM, Galasso G, Birnbaum MJ, Walsh K, Sessa WC. Akt1/protein kinase balpha is critical for ischemic and vegf-mediated angiogenesis. $J$ Clin Invest. 2005;115:2119-2127

109. Scadden DT. The stem-cell niche as an entity of action. Nature. $2006 ; 441: 1075-1079$

110. Aliev G, Shenk JC, Fischbach K, Perry G. Stem cell niches as clinical targets: The future of anti-ischemic therapy? Nat Clin Pract Cardiovasc Med. 2008;5:590-591

111. Kiel MJ, Yilmaz OH, Iwashita T, Terhorst C, Morrison SJ. Slam family receptors distinguish hematopoietic stem and progenitor cells and reveal endothelial niches for stem cells. Cell. 2005;121:1109-1121

112. Votteler M, Kluger PJ, Walles H, Schenke-Layland K. Stem cell microenvironments - unveiling the secret of how stem cell fate is defined. Macromol Biosci. 2010

113. Moore KA, Lemischka IR. Stem cells and their niches. Science. $2006 ; 311: 1880-1885$ 
114. Krause DS, Theise ND, Collector MI, Henegariu O, Hwang S, Gardner R, Neutzel S, Sharkis SJ. Multi-organ, multi-lineage engraftment by a single bone marrow-derived stem cell. Cell. 2001;105:369-377

115. Johe KK, Hazel TG, Muller T, Dugich-Djordjevic MM, McKay RD. Single factors direct the differentiation of stem cells from the fetal and adult central nervous system. Genes Dev. 1996;10:3129-3140

116. Peterson LD, Jeffery NM, Thies F, Sanderson P, Newsholme EA, Calder PC. Eicosapentaenoic and docosahexaenoic acids alter rat spleen leukocyte fatty acid composition and prostaglandin e 2 production but have different effects on lymphocyte functions and cell-mediated immunity. Lipids. 1998;33:171-180

117. Kojima T, Kamei H, Kondo T, Nakashima I, Kato N. Differential effector functions of central and peripheral compartments of immune response system: Characterization of immune responses in the spleen and mesenteric lymph nodes to directly injected sheep red blood cells. Immunobiology. 1982;161:442-456

118. Hill DA, Swanson PE. Myocardial extramedullary hematopoiesis: A clinicopathologic study. Mod Pathol. 2000;13:779-787

119. Hamaguchi I, Huang XL, Takakura N, Tada J, Yamaguchi $Y$, Kodama $H$, Suda T. In vitro hematopoietic and endothelial cell development from cells expressing tek receptor in murine aorta-gonad-mesonephros region. Blood. 1999;93:1549-1556 
120. Nishikawa M, Tahara T, Hinohara A, Miyajima A, Nakahata T, Shimosaka A. Role of the microenvironment of the embryonic aorta-gonadmesonephros region in hematopoiesis. Ann N Y Acad Sci. 2001;938:109116

121. Tamura H, Okamoto S, Iwatsuki K, Futamata $Y$, Tanaka K, Nakayama $Y$, Miyajima A, Hara T. In vivo differentiation of stem cells in the aorta-gonadmesonephros region of mouse embryo and adult bone marrow. Exp Hematol. 2002;30:957-966

122. Kodama S, Davis M, Faustman DL. Regenerative medicine: A radical reappraisal of the spleen. Trends Mol Med. 2005;11:271-276

123. Stroncek DF, Dittmar K, Shawker T, Heatherman A, Leitman SF. Transient spleen enlargement in peripheral blood progenitor cell donors given g-csf. $J$ Transl Med. 2004;2:25

124. Zhao X, Qian D, Wu N, Yin Y, Chen J, Cui B, Huang L. The spleen recruits endothelial progenitor cell via sdf-1/cxcr4 axis in mice. J Recept Signal Transduct Res. 2010;30:246-254

125. Kwon SM, Alev C, Asahara T. The role of notch signaling in endothelial progenitor cell biology. Trends Cardiovasc Med. 2009;19:170-173

126. Zengin $E$, Chalajour F, Gehling UM, Ito WD, Treede $H$, Lauke $H$, Weil J, Reichenspurner $\mathrm{H}$, Kilic $\mathrm{N}$, Ergun $\mathrm{S}$. Vascular wall resident progenitor cells: A source for postnatal vasculogenesis. Development. 2006;133:1543-1551 
127. Tilki D, Hohn HP, Ergun B, Rafii S, Ergun S. Emerging biology of vascular wall progenitor cells in health and disease. Trends Mol Med. 2009;15:501509

128. Urbich C, Aicher A, Heeschen C, Dernbach E, Hofmann WK, Zeiher AM, Dimmeler S. Soluble factors released by endothelial progenitor cells promote migration of endothelial cells and cardiac resident progenitor cells. J Mol Cell Cardiol. 2005;39:733-742

129. Han J, Koh YJ, Moon HR, Ryoo HG, Cho CH, Kim I, Koh GY. Adipose tissue is an extramedullary reservoir for functional hematopoietic stem and progenitor cells. Blood. 2010;115:957-964

130. Conigliaro A, Colletti M, Cicchini C, Guerra MT, Manfredini R, Zini R, Bordoni V, Siepi F, Leopizzi M, Tripodi M, Amicone L. Isolation and characterization of a murine resident liver stem cell. Cell Death Differ. 2008; 15:123-133

131. Majka SM, Beutz MA, Hagen M, Izzo AA, Voelkel N, Helm KM. Identification of novel resident pulmonary stem cells: Form and function of the lung side population. Stem Cells. 2005;23:1073-1081

132. Nagayoshi K, Ohkawa H, Yorozu K, Higuchi M, Higashi S, Kubota N, Fukui H, Imai N, Gojo S, Hata J, Kobayashi Y, Umezawa A. Increased mobilization of c-kit+ sca-1+ lin- $(\mathrm{ksl})$ cells and colony-forming units in spleen (cfu-s) following de novo formation of a stem cell niche depends on dynamic, but not stable, membranous ossification. J Cell Physiol. 2006;208:188-194 
133. Aicher A, Rentsch M, Sasaki K, Ellwart JW, Fandrich F, Siebert R, Cooke JP, Dimmeler S, Heeschen C. Nonbone marrow-derived circulating progenitor cells contribute to postnatal neovascularization following tissue ischemia. Circ Res. 2007;100:581-589

134. Wassmann S, Werner N, Czech T, Nickenig G. Improvement of endothelial function by systemic transfusion of vascular progenitor cells. Circ Res. 2006;99:e74-83

135. Majka SM, Jackson KA, Kienstra KA, Majesky MW, Goodell MA, Hirschi KK. Distinct progenitor populations in skeletal muscle are bone marrow derived and exhibit different cell fates during vascular regeneration. $J$ Clin Invest. 2003;111:71-79

136. Hill JM, Zalos G, Halcox JP, Schenke WH, Waclawiw MA, Quyyumi AA, Finkel T. Circulating endothelial progenitor cells, vascular function, and cardiovascular risk. N Engl J Med. 2003;348:593-600

137. Iwaguro H, Yamaguchi J, Kalka C, Murasawa S, Masuda H, Hayashi S, Silver M, Li T, Isner JM, Asahara T. Endothelial progenitor cell vascular endothelial growth factor gene transfer for vascular regeneration. Circulation. 2002;105:732-738

138. Kan H, Heiss G, Rose KM, Whitsel EA, Lurmann F, London SJ. Prospective analysis of traffic exposure as a risk factor for incident coronary heart disease: The atherosclerosis risk in communities (aric) study. Environ Health Perspect. 2008;116:1463-1468 
139. Hoffmann B, Moebus S, Mohlenkamp S, Stang A, Lehmann N, Dragano $\mathrm{N}$, Schmermund A, Memmesheimer M, Mann K, Erbel R, Jockel KH. Residential exposure to traffic is associated with coronary atherosclerosis. Circulation. 2007;116:489-496

140. Rosenlund M, Bellander $T$, Nordquist $T$, Alfredsson $L$. Traffic-generated air pollution and myocardial infarction. Epidemiology. 2009;20:265-271

141. Clancy L, Goodman P, Sinclair H, Dockery DW. Effect of air-pollution control on death rates in dublin, ireland: An intervention study. Lancet. $2002 ; 360: 1210-1214$

142. McCracken JP, Smith KR, Diaz A, Mittleman MA, Schwartz J. Chimney stove intervention to reduce long-term wood smoke exposure lowers blood pressure among guatemalan women. Environ Health Perspect. 2007;115:996-1001

143. Alfredsson L, Hammar N, Hogstedt C. Incidence of myocardial infarction and mortality from specific causes among bus drivers in sweden. Int $J$ Epidemiol. 1993;22:57-61

144. Hansen ES. Mortality from cancer and ischemic heart disease in danish chimney sweeps: A five-year follow-up. Am J Epidemiol. 1983;117:160164

145. Choi BC. A technique to re-assess epidemiologic evidence in light of the healthy worker effect: The case of firefighting and heart disease. J Occup Environ Med. 2000;42:1021-1034 
146. Ambrose JA, Barua RS. The pathophysiology of cigarette smoking and cardiovascular disease: An update. J Am Coll Cardiol. 2004;43:1731-1737

147. Barnoya J, Glantz SA. Cardiovascular effects of secondhand smoke: Nearly as large as smoking. Circulation. 2005;111:2684-2698

148. Lund AK, Lucero J, Lucas S, Madden MC, McDonald JD, Seagrave JC, Knuckles TL, Campen MJ. Vehicular emissions induce vascular mmp-9 expression and activity associated with endothelin-1-mediated pathways. Arterioscler Thromb Vasc Biol. 2009;29:511-517

149. Ghilarducci DP, Tjeerdema RS. Fate and effects of acrolein. Rev Environ Contam Toxicol. 1995;144:95-146

150. Smith D, Cheng $P$, Spanel P. Analysis of petrol and diesel vapour and vehicle engine exhaust gases using selected ion flow tube mass spectrometry. Rapid Commun Mass Spectrom. 2002;16:1124-1134

151. Dong JZ, Moldoveanu SC. Gas chromatography-mass spectrometry of carbonyl compounds in cigarette mainstream smoke after derivatization with 2,4-dinitrophenylhydrazine. J Chromatogr A. 2004;1027:25-35

152. Yoshida M, Tomitori H, Machi Y, Hagihara M, Higashi K, Goda H, Ohya T, Niitsu M, Kashiwagi K, Igarashi K. Acrolein toxicity: Comparison with reactive oxygen species. Biochem Biophys Res Commun. 2009;378:313318 
153. Conklin DJ, Haberzettl P, Prough RA, Bhatnagar A. Glutathione-stransferase $p$ protects against endothelial dysfunction induced by exposure to tobacco smoke. Am.J.Physiol Heart Circ.Physiol. 2009;296:H1586-H1597

154. Campen MJ, Lund AK, Doyle-Eisele ML, McDonald JD, Knuckles TL, Rohr AC, Knipping EM, Mauderly JL. A comparison of vascular effects from complex and individual air pollutants indicates a role for monoxide gases and volatile hydrocarbons. Environ Health Perspect. 2010;118:921-927

155. Seeger FH, Haendeler J, Walter DH, Rochwalsky U, Reinhold J, Urbich C, Rossig L, Corbaz A, Chvatchko Y, Zeiher AM, Dimmeler S. P38 mitogenactivated protein kinase downregulates endothelial progenitor cells. Circulation. 2005;111:1184-1191

156. Stein AB, Tang XL, Guo Y, Xuan YT, Dawn B, Bolli R. Delayed adaptation of the heart to stress: Late preconditioning. Stroke. $2004 ; 35: 2676-2679$

157. Balasubramaniam V, Mervis CF, Maxey AM, Markham NE, Abman SH. Hyperoxia reduces bone marrow, circulating, and lung endothelial progenitor cells in the developing lung: Implications for the pathogenesis of bronchopulmonary dysplasia. Am J Physiol Lung Cell Mol Physiol. 2007;292:L1073-1084

158. Conklin DJ, Haberzettl P, Lesgards JF, Prough RA, Srivastava S, Bhatnagar A. Increased sensitivity of glutathione s-transferase p-null mice to cyclophosphamide-induced urinary bladder toxicity. J Pharmacol Exp Ther. 2009;331:456-469 
159. Pitchford SC, Furze RC, Jones CP, Wengner AM, Rankin SM. Differential mobilization of subsets of progenitor cells from the bone marrow. Cell Stem Cell. 2009;4:62-72

160. Sithu SD, Srivastava S, Siddiqui MA, Vladykovskaya E, Riggs DW, Conklin DJ, Haberzettl P, O'Toole TE, Bhatnagar A, D'Souza SE. Exposure to acrolein by inhalation causes platelet activation. Toxicol Appl Pharmacol. 2010;248:100-110

161. Kondo T, Hayashi M, Takeshita K, Numaguchi $Y$, Kobayashi K, lino S, Inden $Y$, Murohara T. Smoking cessation rapidly increases circulating progenitor cells in peripheral blood in chronic smokers. Arterioscler Thromb Vasc Biol. 2004;24:1442-1447

162. Heiss C, Amabile N, Lee AC, Real WM, Schick SF, Lao D, Wong ML, Jahn S, Angeli FS, Minasi P, Springer ML, Hammond SK, Glantz SA, Grossman W, Balmes JR, Yeghiazarians Y. Brief secondhand smoke exposure depresses endothelial progenitor cells activity and endothelial function: Sustained vascular injury and blunted nitric oxide production. $J$ Am Coll Cardiol. 2008;51:1760-1771

163. Lin HH, Chen YH, Yet SF, Chau LY. After vascular injury, heme oxygenase-1/carbon monoxide enhances re-endothelialization via promoting mobilization of circulating endothelial progenitor cells. J Thromb Haemost. 2009;7:1401-1408 
164. Marwick JA, Edirisinghe I, Arunachalam G, Stevenson CS, Macnee W, Kirkham PA, Rahman I. Cigarette smoke regulates vegfr2-mediated survival signaling in rat lungs. $J$ Inflamm (Lond).7:11

165. Wang GW, Guo Y, Vondriska TM, Zhang J, Zhang S, Tsai LL, Zong NC, Bolli R, Bhatnagar A, Prabhu SD. Acrolein consumption exacerbates myocardial ischemic injury and blocks nitric oxide-induced pkcepsilon signaling and cardioprotection. J.Mol.Cell Cardiol. 2008;44:1016-1022

166. Anderson MM, Hazen SL, Hsu FF, Heinecke JW. Human neutrophils employ the myeloperoxidase-hydrogen peroxide-chloride system to convert hydroxy-amino acids into glycolaldehyde, 2-hydroxypropanal, and acrolein. A mechanism for the generation of highly reactive alpha-hydroxy and alpha,beta-unsaturated aldehydes by phagocytes at sites of inflammation. J.Clin.Invest. 1997;99:424-432

167. Mellick AS, Plummer PN, Nolan DJ, Gao D, Bambino K, Hahn M, Catena R, Turner V, McDonnell K, Benezra R, Brink R, Swarbrick A, Mittal V. Using the transcription factor inhibitor of DNA binding 1 to selectively target endothelial progenitor cells offers novel strategies to inhibit tumor angiogenesis and growth. Cancer Res. 2010;70:7273-7282

168. Pipp F, Heil M, Issbrucker K, Ziegelhoeffer T, Martin S, van den Heuvel J, Weich H, Fernandez B, Golomb G, Carmeliet P, Schaper W, Clauss M. Vegfr-1-selective vegf homologue plgf is arteriogenic: Evidence for a monocyte-mediated mechanism. Circ Res. 2003;92:378-385 
169. Isner JM, Asahara T. Angiogenesis and vasculogenesis as therapeutic strategies for postnatal neovascularization. J Clin Invest. 1999;103:12311236

170. Bauer SM, Bauer RJ, Velazquez OC. Angiogenesis, vasculogenesis, and induction of healing in chronic wounds. Vasc Endovascular Surg. $2005 ; 39: 293-306$

171. leda Y, Fujita J, leda M, Yagi T, Kawada H, Ando K, Fukuda K. G-csf and hgf: Combination of vasculogenesis and angiogenesis synergistically improves recovery in murine hind limb ischemia. $J$ Mol Cell Cardiol. $2007 ; 42: 540-548$

172. Klein S, de Fougerolles AR, Blaikie P, Khan L, Pepe A, Green CD, Koteliansky V, Giancotti FG. Alpha 5 beta 1 integrin activates an nf-kappa b-dependent program of gene expression important for angiogenesis and inflammation. Mol Cell Biol. 2002;22:5912-5922

173. Gouras GK. Current theories for the molecular and cellular pathogenesis of alzheimers disease. Expert Rev Mol Med. 2001;2001:1-11

174. Chung NA, Lydakis C, Belgore F, Li-Saw-Hee FL, Blann AD, Lip GY. Angiogenesis, thrombogenesis, endothelial dysfunction and angiographic severity of coronary artery disease. Heart. 2003;89:1411-1415

175. Clarkson TB, Prichard RW, Bullock BC, St Clair RW, Lehner ND, Jones DC, Wagner WD, Rudel LL. Pathogenesis of artherosclerosis; some advances from using animal models. Exp Mol Pathol. 1976;24:264-286 
176. Waltenberger J. Vegf resistance as a molecular basis to explain the angiogenesis paradox in diabetes mellitus. Biochem Soc Trans.

2009;37:1167-1170

177. Hamanaka T, Akabane N, Yajima T, Takahashi T, Tanabe A. Retinal ischemia and angle neovascularization in proliferative diabetic retinopathy. Am J Ophthalmol. 2001;132:648-658

178. Petrakis IE, Sciacca V. Does autonomic neuropathy influence spinal cord stimulation therapy success in diabetic patients with critical lower limb ischemia? Surg Neurol. 2000;53:182-188; discussion 188-189

179. Melin J, Hellberg O, Akyurek LM, Kallskog O, Larsson E, Fellstrom BC. Ischemia causes rapidly progressive nephropathy in the diabetic rat. Kidney Int. 1997;52:985-991

180. Kiechl S, Werner P, Egger G, Oberhollenzer F, Mayr M, Xu Q, Poewe W, Willeit J. Active and passive smoking, chronic infections, and the risk of carotid atherosclerosis: Prospective results from the bruneck study. Stroke. 2002;33:2170-2176

181. Wiesmann F, Petersen SE, Leeson PM, Francis JM, Robson MD, Wang Q, Choudhury R, Channon KM, Neubauer S. Global impairment of brachial, carotid, and aortic vascular function in young smokers: Direct quantification by high-resolution magnetic resonance imaging. J Am Coll Cardiol. 2004;44:2056-2064 
182. Michaud SE, Menard C, Guy LG, Gennaro G, Rivard A. Inhibition of hypoxia-induced angiogenesis by cigarette smoke exposure: Impairment of the hif-1alpha/vegf pathway. Faseb J. 2003;17:1150-1152

183. Hill JM, Finkel T, Quyyumi AA. Endothelial progenitor cells and endothelial dysfunction. Vox Sang. 2004;87 Suppl 2:31-37

184. Turgeon J, Dussault S, Haddad P, Groleau J, Menard C, Michaud SE, Maingrette F, Rivard A. Probucol and antioxidant vitamins rescue ischemia-induced neovascularization in mice exposed to cigarette smoke: Potential role of endothelial progenitor cells. Atherosclerosis.

2010;208:342-349

185. Michaud SE, Dussault S, Haddad P, Groleau J, Rivard A. Circulating endothelial progenitor cells from healthy smokers exhibit impaired functional activities. Atherosclerosis. 2006;187:423-432

186. Hill JM, Zalos G, Halcox JP, Schenke WH, Waclawiw MA, Quyyumi AA, Finkel T. Circulating endothelial progenitor cells, vascular function, and cardiovascular risk. N Engl J Med. 2003;348:593-600

187. Wheat LA, Haberzettl P, Hellmann J, Baba SP, Bertke M, Lee J, McCracken J, O'Toole TE, Bhatnagar A, Conklin DJ. Acrolein inhalation prevents vascular endothelial growth factor-induced mobilization of flk1+/sca-1+ cells in mice. Arterioscler Thromb Vasc Biol. 2011;31:15981606 
188. Sorensen LT, Toft BG, Rygaard J, Ladelund S, Paddon M, James T, Taylor R, Gottrup F. Effect of smoking, smoking cessation, and nicotine patch on wound dimension, vitamin $\mathrm{c}$, and systemic markers of collagen metabolism. Surgery. 2010;148:982-990

189. Haddad P, Dussault S, Groleau J, Turgeon J, Michaud SE, Menard C, Perez G, Maingrette F, Rivard A. Nox2-containing nadph oxidase deficiency confers protection from hindlimb ischemia in conditions of increased oxidative stress. Arterioscler Thromb Vasc Biol. 2009;29:15221528

190. Silvestre JS, Levy BI. Angiogenesis therapy in ischemic disease. Arch Mal Coeur Vaiss. 2002;95:189-196

191. Tongers J, Knapp JM, Korf M, Kempf T, Limbourg A, Limbourg FP, Li Z, Fraccarollo D, Bauersachs J, Han X, Drexler H, Fiedler B, Wollert KC. Haeme oxygenase promotes progenitor cell mobilization, neovascularization, and functional recovery after critical hindlimb ischaemia in mice. Cardiovasc Res. 2008;78:294-300

192. Liu C, Sun Z, Du X, Chen X, Feng J, Jia B. Implantation of endothelial progenitor cells into laser-induced channels in rat ischemia hindlimb augments neovascularization. Ann Vasc Surg. 2005;19:241-247

193. Li Y, Hazarika S, Xie D, Pippen AM, Kontos CD, Annex BH. In mice with type 2 diabetes, a vascular endothelial growth factor (vegf)-activating transcription factor modulates vegf signaling and induces therapeutic angiogenesis after hindlimb ischemia. Diabetes. 2007;56:656-665 
194. Michael Pittilo R. Cigarette smoking, endothelial injury and cardiovascular disease. Int J Exp Pathol. 2000;81:219-230

195. Yue WS, Wang M, Yan GH, Yiu KH, Yin L, Lee SW, Siu CW, Tse HF. Smoking is associated with depletion of circulating endothelial progenitor cells and elevated pulmonary artery systolic pressure in patients with coronary artery disease. Am J Cardiol. 2010;106:1248-1254

196. Holzbach T, Neshkova I, Vlaskou D, Konerding MA, Gansbacher B, Biemer E, Giunta RE. Searching for the right timing of surgical delay: Angiogenesis, vascular endothelial growth factor and perfusion changes in a skin-flap model. J Plast Reconstr Aesthet Surg. 2009;62:1534-1542

197. Isner JM. Tissue responses to ischemia: Local and remote responses for preserving perfusion of ischemic muscle. J Clin Invest. 2000;106:615-619 


\title{
CURRICULUM VITAE
}

Part l: General Information

NAME: Laura Anne Wheat Nissley

Date prepared: 02/04/11

OFFICE ADDRESS:

\author{
Institute of Molecular Cardiology \\ Division of Cardiology \\ Department of Medicine \\ University of Louisville \\ Room 415 Delia Baxter Building \\ 580 S. Preston \\ Louisville, KY 40202 \\ Tel: (502) 852-4239 \\ 7408 Steeplecrest Circle \\ Apt. 206 \\ Louisville, KY 40222 \\ (270) $317-5675$
}

HOME ADDRESS:

FAX: (502) 852-3663

Email: lawhea02@louisville.edu

DATE AND PLACE OF BIRTH: July $5^{\text {th }} 1983$ - Glasgow, Kentucky, U.S.A.

CITIZENSHIP: $\quad$ United States Citizen

EDUCATION:

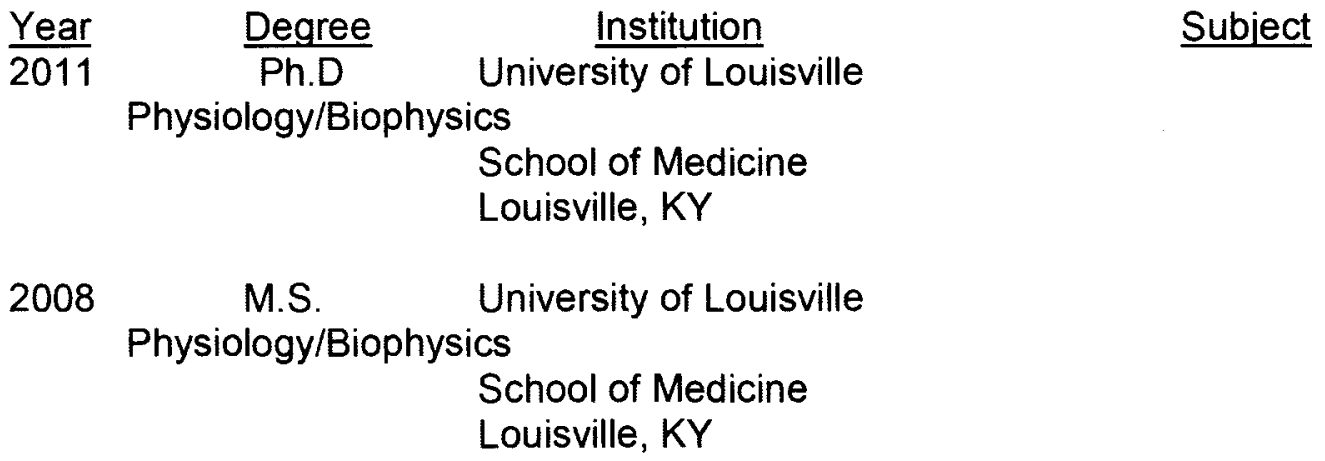




\section{APPOINTMENTS}

September 2002 - December 2003

August 2003 - May 2005

August 2004 - May 2005

COMMUNITY SERVICE

2002-2006

CHARATABLE SERVICE

2008-Present

AWARDS and HONORS

2001

2006
Medical Assistant, Dr. John Kilgallin, Russell Springs, KY

Student Tutor, Lindsey Wilson College, Columbia, KY

Student Assistant Biology Department, Lindsey Wilson College, Columbia, KY

Volunteer - Adanta Adult Day Care

Sponsorship Chair - Lupus foundation Walk for Lupus Now campaign

Kentucky Govenor Scholar

Integrated Programs in Biomedical Sciences (IPIBS) fellowship award

\section{Part II: Research}

My research at the University of Louisville was initiated as an attempt to understand the link between environmental pollution and increased mortality rates. Previous studies have shown a strong negative correlation between pollution and developing heart disease, diabetes, and decreased wound healing ability, however the physiologic reason behind this still remains a mystery. In my research I studied adult endothelial progenitor cells (EPCs), a small subset of cells that have stem cell and endothelial cells properties and heal damaged endothelium. There is also a strong negative correlation between the number of circulating EPC and the risk for developing heart disease, diabetes, and decreased wound healing. Little has been done with the characterization of EPC in mice models, so our lab has done an extensive set of cell markers by flow cytometry and developing the first heirarchy of mouse EPCs. My main field of study came to be EPC and how they were affected by acrolein. Acrolein is a 
highly reactive unsaturated aldehyde present in all forms of pollution in high amounts. In my research I have found acrolein inhalation does indeed decrease circulating endothelial cells and hinders angiogenic assays in vitro, in a time and dose dependant manner. With this knowledge our lab can now began to unravel the mystery behind pollution and high mortality rates, thus decreasing or even preventing pollution related deaths.

\section{Part III: Bibliography}

\section{Original Articles (refereed journals)}

Wheat, L., Hellmann, J., Haberzettl, P., Baba, S., Bertke, M,. Lee, J., McCracken, J., O'Toole, T., Bhatnagar, A., Conklin, D.J. Acrolein inhalation decreases circulating levels and VEGF-induced mobilization of

Flk-1+/Sca-1+ cells. ATVB 2011. (Submitted).

O'Toole, T., Hellmann, J., Wheat, L., Haberzettl, Lee, J., Conclin, D.J., Bhatnagar, A., Pope III, A., Episodic exposure to fine particulate air pollution decreases circulating levels of endothelial progenitor cells. Circulation Research. 107 (200-203), 2010

\section{Dissertation}

Wheat, L. Effects of Environmental Pollution on Endothelial Progenitor Cells and Vascular Regeneration [dissertation] Louisville (KY): University of Louisville; 2011

\section{Abstracts}

Wheat, L., Hellmann, J., Haberzettl, P., Conklin, D.J., O'Toole, T., Bhatnagar,

A., Acrolein Inhalation Decreases Endothelial Progenitor Cell by Suppressing Recruitment and Mobilization. American Heart

Association. 2008

Wheat, L., Hellmann, J., Haberzettl, P., Conklin, D.J., O'Toole, T., Bhatnagar, A.,

Acrolein Suppresses Recruitment and Mobilization of Endothelial

Progenitor Cells Research Louisville 2009

Hellmann, J., Haberzettl, P., Wheat, L., Conklin, D.J., O'Toole, T., Bhatnagar, A.,

Aldose Reductase-Dependant Effects on Endothelial Dysfunction and 
Endothelial Progenitor Cells in Diet Induced Obesity. Research Louisville

2009

Conklin, D.J., Wheat, L., Hellmann, J., Haberzettl, P., O'Toole, T., Bhatnagar,A

Inhaled Acrolein Decreases Circulating Endothelial Progenitor Cells and Their Recruitment. Society of Toxicology poster 2010

Wheat, L., Hellmann, J., Haberzettl, P., Conklin, D.J., O'Toole, T., Bhatnagar, A.,

Acrolein Suppresses Mobilization of Flk-1+/Sca-1+ Progenitor Cells.

FASEB 2010 